\title{
Geologic and Hydrologic Data for the Municipal Solid Waste Landfill Facility, U.S. Army Air Defense Artillery Center and Fort Bliss, El Paso County, Texas
}

By Cynthia G. Abeyta and Peter F. Frenzel

U.S. GEOLOGICAL SURVEY

Open-File Report 99-271

Prepared in cooperation with the

U.S. DEPARTMENT OF THE ARMY,

U.S. ARMY AIR DEFENSE ARTILLERY CENTER AND FORT BLISS 


\section{U.S. DEPARTMENT OF THE INTERIOR \\ BRUCE BABBITT, Secretary}

U.S. GEOLOGICAL SURVEY

Charles G. Groat, Director

The use of firm, trade, and brand names in this report is for identification purposes only and does not constitute endorsement by the U.S. Geological Survey.

For additional information write to:

Copies of this report can be purchased from:

District Chief

U.S. Geological Survey

Water Resources Division

5338 Montgomery NE, Suite 400

U.S. Geological Survey

Branch of Information Services

Box 25286

Denver, CO 80225-0286

Albuquerque, NM 87109-1311

Information regarding research and data-collection programs of the U.S. Geological Survey is available on the Internet via the World Wide Web. You may connect to the Home Page for the New Mexico District Office using the URL: http://nm.water.usgs.gov 


\section{CONTENTS}

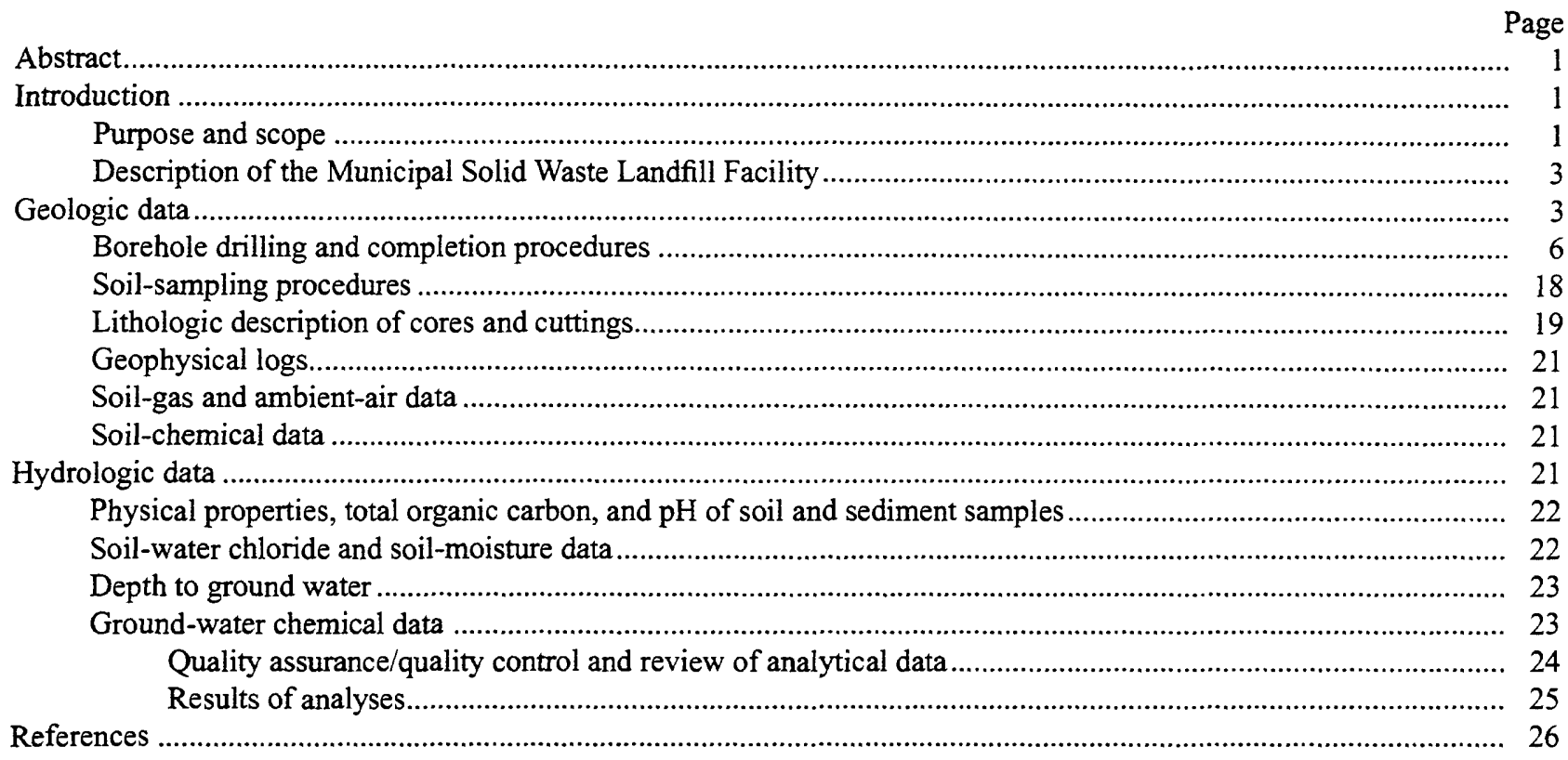

\section{PLATE}

[Plate is in pocket]

1. Lithologic and geophysical logs, soil-chemical and physical property references, soil-chloride concentrations, and volumetric soil moisture of sediments in boreholes BH-3 and MSWLF03.

\section{FIGURES}

1-3. Maps showing:

1. Location of U.S. Army Air Defense Artillery Center and Fort Bliss military reservation and Municipal Solid Waste Landfill Facility, Texas and New Mexico.

2. Location of U.S. Army Air Defense Artillery Center and Fort Bliss Municipal Solid Waste Landfill Facility, El Paso, Texas

3. Municipal Solid Waste Landfill Facility boundary and location of gas-monitoring boreholes, borehole BH-3, ground-water monitoring well MSWLF03, and landfill-cover sampling sites.................. $\quad 5$

4-14. Diagrams showing:

4. Completion of gas-monitoring probe GMP-1

5. Completion of gas-monitoring probe GMP-2

6. Completion of gas-monitoring probe GMP-3

7. Completion of gas-monitoring probe GMP-4

8. Completion of gas-monitoring probe GMP-5

9. Completion of gas-monitoring probe GMP-6

10. Completion of gas-monitoring probe GMP-7.

11. Completion of gas-monitoring probe GMP-8

12. Completion of gas-monitoring probe GMP-9. 
13. Completion of gas-monitoring probe GMP-10

14. Completion of ground-water monitoring well MSWLF03 ...

\section{TABLES}

1. Lithology penetrated by borehole GMP-1

2. Lithology penetrated by borehole GMP-2

3. Lithology penetrated by borehole GMP-3

4. Lithology penetrated by borehole GMP-4

5. Lithology penetrated by borehole GMP-5

6. Lithology penetrated by borehole GMP-6.

7. Lithology penetrated by borehole GMP-7

8. Lithology penetrated by borehole GMP-8.

9. Lithology penetrated by borehole GMP-9

10. Lithology penetrated by borehole GMP-10.

11. Lithology penetrated by borehole BH-3

12. Lithology penetrated by borehole MSWLF03

13. Analytical results of soil-gas and ambient-air samples collected at the Municipal Solid Waste Landfill

Facility, U.S. Army Air Defense Artillery Center and Fort Bliss, El Paso, Texas, December 1994.

14. Analytical results of soil-gas and ambient-air samples collected at the Municipal Solid Waste Landfill

Facility, U.S. Army Air Defense Artillery Center and Fort Bliss, El Paso, Texas, March 1995

15. Analytical results of soil-gas and ambient-air samples collected at the Municipal Solid Waste Landfill

Facility, U.S. Army Air Defense Artillery Center and Fort Bliss, El Paso, Texas, June 1995

16. Analytical results of soil-gas and ambient-air samples collected at the Municipal Solid Waste Landfill

Facility, U.S. Army Air Defense Artillery Center and Fort Bliss, El Paso, Texas, September 1995

17. Soil-chemical results of soil samples collected from borehole BH-3, Municipal Solid Waste Landfill

Facility, U.S. Army Air Defense Artillery Center and Fort Bliss, El Paso, Texas

18. Data-qualifier codes used to qualify chemical-analytical data

19. Analytical methods used for physical properties, total organic carbon, and $\mathrm{pH}$ analysis of soil samples collected from boreholes BH-3 and MSWLF03, U.S. Army Air Defense Artillery Center and Fort Bliss, El Paso, Texas

20. Initial moisture content, dry bulk density, calculated porosity, saturated hydraulic conductivity, total organic carbon, and pH of core samples collected from boreholes BH-3 and MSWLF03, Municipal Solid W'aste Landfill Facility, U.S. Army Air Defense Artillery Center and Fort Bliss, El Paso, Texas.

21. Moisture content, measured at various pressure heads, of core samples collected from boreholes BH-3 and MSWLF03, Municipal Solid Waste Landfill Facility, U.S. Army Air Defense Artillery Center and Fort Bliss, El Paso, Texas

22. Van Genuchten alpha and beta coefficients calculated using van Genuchten equations with measured values for residual and saturated soil-water content and saturated hydraulic conductivity from core samples collected from boreholes BH-3 and MSWLF03, Municipal Solid Waste Landfill Facility, U.S. Army Air Defense Artillery Center and Fort Bliss, El Paso, Texas

23. Air entry value and Brooks and Corey exponent derived for core samples collected from boreholes BH-3 and MSWLF03, Municipal Solid Waste Landfill Facility, U.S. Army Air Defense Artillery Center and Fort Bliss, El Paso, Texas

24. Particle-size characteristics of core samples collected from boreholes BH-3 and MSWLF03, Municipal Solid Waste Landfill Facility, U.S. Army Air Defense Artillery Center and Fort Bliss, El Paso, Texas.

25. Analytical methods used for physical analyses of soil samples collected from the landfill cover, Municipal Solid Waste Landfill Facility, U.S. Army Air Defense Artillery Center and Fort Bliss, El Paso, Texas

26. Initial moisture content, dry bulk density, and calculated porosity of soil samples collected from the landfill cover, Municipal Solid Waste Landfill Facility, U.S. Army Air Defense Artillery Center and Fort Bliss, El Paso, Texas 
27. Moisture content, measured at various pressure heads, of soil samples collected from the landfill cover, Municipal Solid Waste Landfill Facility, U.S. Army Air Defense Artillery Center and Fort Bliss, El Paso, Texas

28. Infiltration rate and hydraulic conductivity of the landfill cover, Municipal Solid Waste Landfill Facility, U.S. Army Air Defense Artillery Center and Fort Bliss, El Paso, Texas

29. Analytical results of soil-moisture and soil-chloride data for soil samples collected from cores from the Municipal Solid Waste Landfill Facility, U.S. Army Air Defense Artillery Center and Fort Bliss, El Paso, Texas

30. Analytical results of ground-water sample collected from well MSWLF03, Municipal Solid Waste Landfill Facility, U.S. Army Air Defense Artillery Center and Fort Bliss, El Paso, Texas

31. Summary of maximum contaminant levels for selected water-quality constituents and properties for public water-supply systems.

\section{CONVERSION FACTORS AND VERTICAL DATUM}

\begin{tabular}{rcl}
\hline Multiply & By & To obtain \\
\hline inch & 25.40 & millimeter \\
foot & 0.3048 & meter \\
mile & 1.609 & kilometer \\
acre & 4,047 & square meter \\
quart & 0.9464 & liter \\
gallon & 3.785 & liter \\
foot per mile & 0.1894 & meter per kilometer \\
ounce & 28.35 & gram \\
\hline
\end{tabular}

Temperature in degrees Celsius $\left({ }^{\circ} \mathrm{C}\right)$ or degrees Fahrenheit $\left({ }^{\circ} \mathrm{F}\right)$ can be converted as follows:

$$
\begin{aligned}
& { }^{\circ} \mathrm{F}=1.8\left({ }^{\circ} \mathrm{C}\right)+32 \\
& { }^{\circ} \mathrm{C}=5 / 9\left({ }^{\circ} \mathrm{F}-32\right)
\end{aligned}
$$

Sea level: In this report, "sea level" refers to the National Geodetic Vertical Datum of 1929-a geodetic datum derived from a general adjustment of the first-order level nets of the United States and Canada, formerly called Sea Level Datum of 1929. 


\title{
GEOLOGIC AND HYDROLOGIC DATA FOR THE MUNICIPAL SC LID WASTE LANDFILL FACILITY, U.S. ARMY AIR DEFENSE ARTILLERY CENTER AND FORT BLISS, EL PASO COUNTY, TEXAS
}

\author{
By Cynthia G. Abeyta and Peter F. Frenzel
}

\section{Abstract}

Geologic and hydrologic data for the Municipal Solid Waste Landfill Facility on the U.S. Army Air Defense Artillery Center and Fort Bliss in El Paso County, Texas, were collected by the U.S. Geological Survey in cooperation with the U.S. Department of the Army. The 106.03-acre landfill has been in operation since January 1974. The landfill contains household refuse, Post solid wastes, bulky items, grass and tree trimmings from family housing, refuse from litter cans, construction debris, classified waste (dry), dead animals, asbestos, and empty oil cans. The depth of the filled areas is about 30 feet and the cover, consisting of locally derived material, is 2 to 3 feet thick.

Geologic and hydrologic data were collected at or adjacent to the landfill during (1) drilling of 1030 - to 31 -foot boreholes that were completed with gas-monitoring probes, (2) drilling of a 59-foot borehole, (3) drilling of a 355foot borehole that was completed as a groundwater monitoring well, and (4) in situ measurements made on the landfill cover. After completion, the gas-monitoring probes were monitored on a quarterly basis ( 1 year total) for gases generated by the landfill. Water samples were collected from the ground-water monitoring well for chemical analysis.

Data collection is divided into two elements: geologic data and hydrologic data. Geologic data include lithologic descriptions of cores and cuttings, geophysical logs, soil-gas and ambient-air analyses, and chemical analyses of soil. Hydrologic data include physical properties, total organic carbon, and $\mathrm{pH}$ of soil and sediment samples; soil-water chloride and soil-moisture analyses; physical properties of the landfill cover; measurements of depth to ground water; and ground-water chemical analyses. Interpretation of data is not included in this report.

\section{INTRODUCTION}

The U.S. Army Air Defense Artillery Center and Fort Bliss (USAADACENFB) Municipal Solid Waste Landfill Facility (MSWLF or "landfill"), established in January 1974 , is a 106.03 -acre landfill located within El Paso County, Texas, about 10 miles northeast of downtown EI Paso, on Federal land administered by the USAADACENFB (fig. 1). The USAADACENFB is evaluating geologic and hydrologic condition - of the MSWLF to implement requirements of Federal and State of Texas regulatory programs. In 1994, the U.S. Geological Survey (USGS), in cooperation with the U.S. Army, initiated a study of the USAADACENFB MSWLF to describe geologic and hydrologic conditions at the facility. Results of this study rill be used by the U.S. Army to aid in fulfilling regulatory requirements at the facility, as specified in Title 40 of the Code of Federal Regulations, Parts 257 and 258 (40 CFR 257 and 258), Subtitle D (U.S. Environmental Protection Agency, 1993), and Part 30 of the Texas Administrative Code, Section 330 (30 TAC 330) (Texas Natural Resources Conservation Commission, 1993).

\section{Purpose and Scope}

This report presents data collected by the USGS at the MSWLF during 1994 and 1995. This compilation of data will result in a better understanding of the geology and hydrology at the MSWLF. Geologic and hydrologic data presented in this report were collected on and adjacent to the landfill. These data were collected during (1) drilling and installation of 10 gas-monitoring probes (GMPs), (2) drilling of a 59foot borehole that was plugged and abandoned after completion, (3) drilling of a 355-foot borehole th at was completed as a ground-water monitoring well, and (4) in situ measurements made on the landfill cover. 


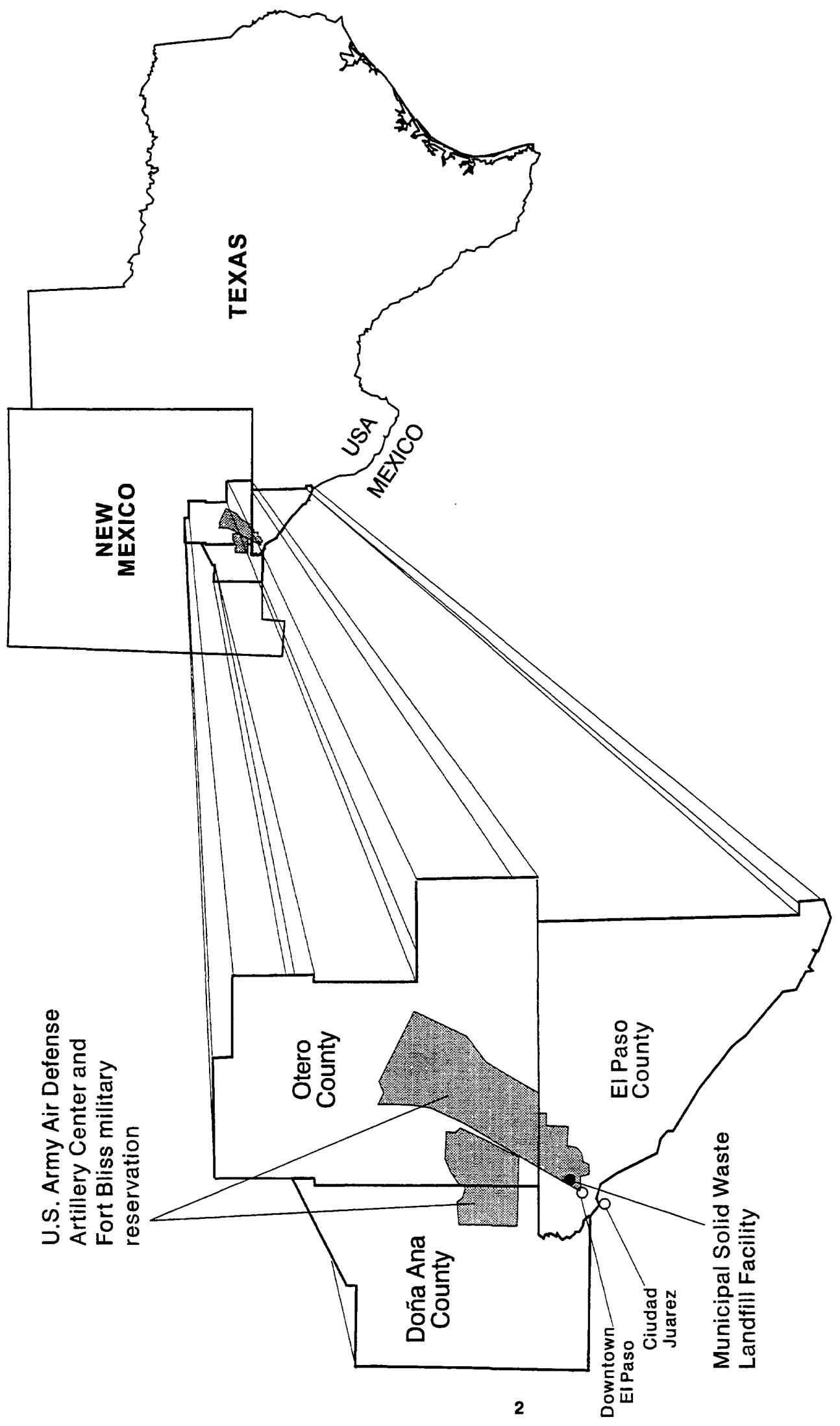

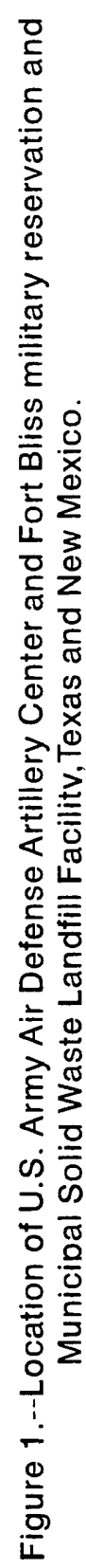


Most of the data were collected in accordance with Texas Natural Resources Conservation Commission (TNRCC)-approved plans and specifications to maintain a consistent data collection program. These plans and specifications are described in the following documents:

(1) Workplan for methane monitoring network at the Municipal Solid Waste Landfill Facility, U.S. Army Air Defense Artillery Center and Fort Bliss, El Paso, Texas, Final (U.S. Geological Survey, written commun., November 1994);

(2) Workplan for ground-water monitoring at the Municipal Solid Waste Landfill Facility, U.S. Army Air Defense Artillery Center and Fort Bliss, El Paso, Texas, Final (U.S. Geological Survey, written commun., March 1995); and

(3) Sampling and analysis plan for groundwater monitoring at the Municipal Solid Waste Landfill Facility, U.S. Army Air Defense Artillery Center and Fort Bliss, El Paso, Texas, Final (U.S. Geological Survey, written commun., March 1995).

In addition to data collected as described above, additional data were collected to evaluate the transport of solutes from the landfill to the water table.

Data collected by the USGS at the MSWLF included lithologic descriptions of cores and cuttings; geophysical logs; soil-gas and ambient-air analyses; chemical analyses of soil; physical-property, total organic carbon, and $\mathrm{pH}$ analyses of soil and sediment samples; soil-water chloride and soil-moisture analyses; physical properties of the landfill cover; measurements of depth to ground water; and groundwater chemical analyses. Interpretation of data is not included in this report.

\section{Description of the Municipal Solid Waste Landfill Facility}

The MSWLF, established in January 1974, is located northwest of Biggs Army Airfield, 300 feet east of the Southern Pacific Railroad tracks, and about 1,200 feet east of the nearest occupied structure (fig. 2). The landfill fill rate is $1-4$ acres per year and at this fill rate the landfill is expected to reach its capacity by 2004 (approximately 15 acres of the permitted area will not be filled). Types of solid wastes disposed of at the MSWLF include household refuse, Post solid wastes, bulky items, grass and tree trimmings from family housing, refuse from litter cans, construction drbris, classified waste (dry), dead animals, asbestos, and empty oil cans (1-quart and 5-gallon sizes). The depth of the filled areas is about 30 feet and the cover, consisting of locally derived material, is 2 to 3 feet thick. Since 1994, the filled area (labeled Subtitle D in fig. 3) has been lined with soil and plastic, as reרuired under Subtitle D regulations (40 CFR Part 258) (Abeyta, 1996, p. 16).

An all-weather road is accessible to the MSWLF year round. The MSWLF is surrounded by a fence with an unfilled border area between the fence and th 9 landfill that is about 50 feet wide (fig. 3). An en losed guard shack is located on the facility near the entrance. Bladed strips on both sides of the landfill fence serve as access roads. The roads are a few inches below the surface of the land surrounding the landfill and are separated by a small berm at the fence line. The landsurface elevation is about 3,920 feet above sea level near the landfill. The landfill rises on a slope of about 3 percent to about 10 feet above the surrounding tirrain. The hummocky land surface around the MSWLF generally slopes about 20 feet per mile toward the south-southwest. No utilities are within the perimeter of the MSWLF.

A previous study by Abeyta (1996) presents a geohydrologic site characterization of the USAADACENFB MSWLF that includes information on the (1) boundaries, area, and contents of the MSWLF; (2) environmental setting of the MSWI.F and vicinity, including a description of the physiograny, climate, and soils; (3) geologic and hydrologic characteristics of the unsaturated zone and shallow aquifer; and (4) ground-water quality in the vicinity of the MSWLF.

\section{GEOLOGIC DATA}

Geologic data were collected at or adjacent to the MSWLF during the drilling of 12 boreholes. In November 1994, 1030 - to 31 -foot vertical boreholes (GMP-1 through GMP-10) were drilled around the perimeter of the landfill (fig. 3). Drill cuttings frcm the boreholes were described and compiled into lithologic logs. Permanent gas-monitoring probes were installed in the boreholes in accordance with requirements listed in $30 \mathrm{TAC} 330.56(\mathrm{a})(2)$. The monitoring network was designed to collect representative samples of exp'nsive gases (specifically methane) generated by the facility 

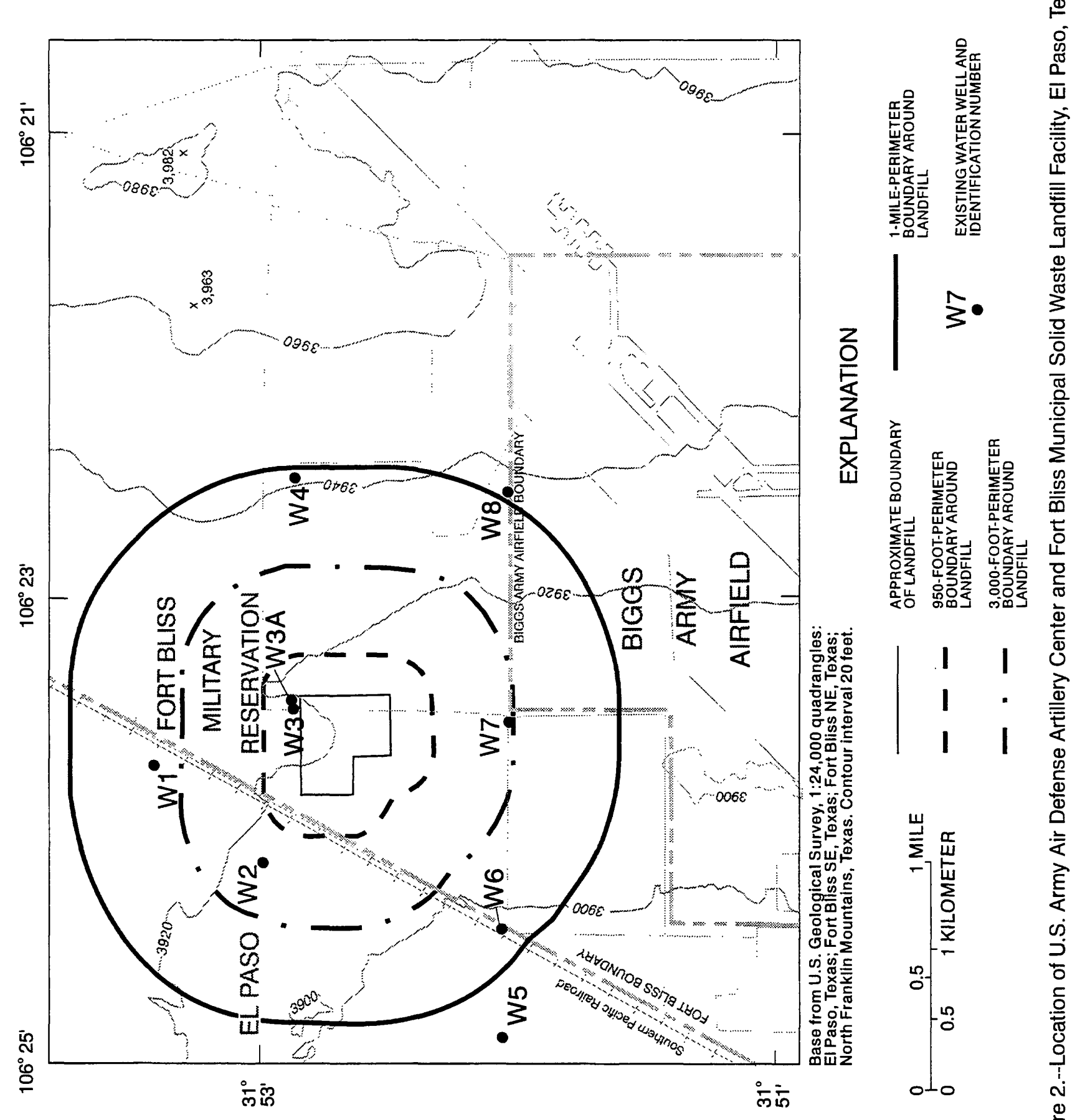


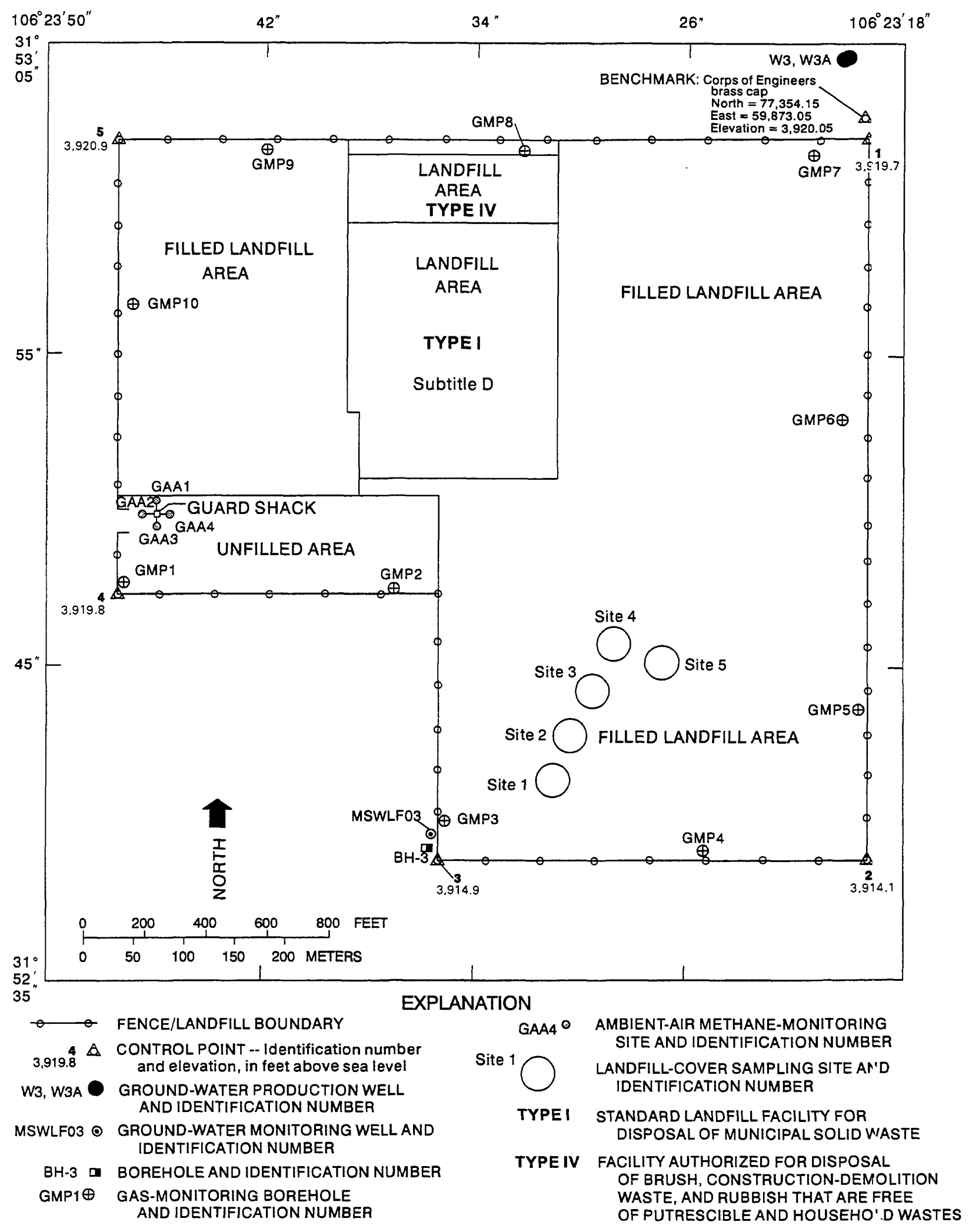

Figure 3.--Municipal Solid Waste Landfill Facility boundary and location of gas-monitoring boreholes, borehole BH-3, ground-water monitoring well MSWLF03, and landfill-cover sampling sites. 
and to monitor whether these gases exceed maximum allowable levels as defined in RCRA Subtitle D (40 CFR 258.23(d) and 30 TAC 330.56(n)(2)). During April-May 1995, one 59-foot vertical borehole (BH-3) and one 355-foot vertical borehole (MSWLF03) were drilled near the southwest corner of the landfill (fig. 3). Core samples were collected during drilling of these two boreholes and the lithology of the recovered cores were described. Samples were collected from selected intervals of the recovered cores that were representative of the various lithologic units (such as clay, sand, and silty sand). These samples were sent to various laboratories for physical-property, soil-water chloride, soil-moisture, and chemical analysis. Geophysical logs were obtained from the mud-filled borehole MSWLF03. The 355-foot borehole was completed as a ground-water monitoring well in accordance with requirements listed in 30 TAC 330 Subchapter I. Geologic data collected at the MSWLF are presented in the following sections.

\section{Borehole Drilling and Completion Procedures}

Boreholes GMP-1 through GMP-10 and BH-3 were drilled using a hollow-stem auger. Boreholes GMP-1 through GMP-10 were drilled to depths of 30 to 31 feet below land surface; borehole $\mathrm{BH}-3$ was drilled to a depth of 59 feet. Borehole BH-3 was plugged and marked with a cement cap. The boreholes were $83 / 4$ inches in diameter. A 4-inch-diameter core was collected at 2- to 5-foot intervals using a 5-footlong split-spoon sampler and continuous flight auger; at times a stainless steel catcher was placed in the shoe of the split-spoon to achieve better recoveries in unconsolidated geologic formations. The sampler was pushed into the undisturbed material below the auger, withdrawn, and opened. All cores collected were then described; at times, cuttings were described when there was no recovery of the core. The descriptions of cores and cuttings are presented in the "Lithologic description of cores and cuttings" section of this report.

Gas-monitoring probes were installed in boreholes GMP-1 through 10 immediately after each borehole was drilled to total depth; completion diagrams are presented in figures 4-13. A 24.55-footlong, 1-inch-diameter, threaded polyvinyl chloride (PVC), 0.010-inch slotted screen was inserted into the borehole while the auger flights were still in the ground; the bottom of the screen was capped. A 7.25foot-long, 1 -inch-diameter, threaded PVC riser was placed directly above the screen. The top of the riser was capped with a reducer/coupling, a PVC 1 all valve, more couplings and reducers, and one-quarter-inch polyethylene tubing. The auger flights were withdrawn as the annular space of the borehole was filled with a three-eighths-inch pea gravel filter pack. The filter pack was placed to about 5 feet below land surface; at times the annular space in the borehole fillec with natural backfill when the hole would not remain open without the auger flights. A 3-linear-foot seal of hydrated bentonite pellets was placed above the filter pack. The annular space above the bentonite seal was filled with concrete to the ground surface. A 3-footsquare concrete surface pad surrounds a lock'ng, steel, protective casing that extends 2 to 3 feet above ground level and contains the 1-inch PVC riser and probe. Four 3 -inch-diameter steel guard posts were place $t$ at each corner of the surface pad that extend about 3 feet above the land surface.

The borehole for ground-water monitcring well MSWLF03 was drilled using mud-rotary drilling techniques and bentonite mud. A diamond-button corebit was attached to the bottom of the drill string, which contained a 10-foot-long, 3.5-inch-diameter core barrel; at times a stainless steel catcher was $\mathrm{f}^{\mathrm{l}}$ aced in the shoe of the core barrel to achieve better recoveries. The drill string was rotated while coring to expose the core-bit's buttons to the full annular area of the undisturbed material at the bottom of the drill string. An approximately 3.5-inch-diameter core was collected in the stainless steel split-core barrel. The core barrel was withdrawn, opened, and the core collected and described. The descriptions of cores and cuttings are presented in the "Lithologic description of cores and cuttings" section of this report.

Prior to completion as ground-water monitoring well MSWLF03, the borehole was reamed to a total depth of 355 feet. Completion of the well consisted of a 3.826-inch-inside-diameter, 4.5-inch-outsic'ediameter, flush-joint, threaded, schedule 80 PVC sump, screen, and riser (fig. 14). A 40-foot-long scrsen with 0.010 -inch-wide slotted openings was attached to the 5-foot-long sump; an approximately 307 -foot-long riser was attached to the screen. The annular space of the borehole was gravel packed with $10-20$ m sh clean silica sand tremmied from the bottom of the hole to about 11 feet above the top of the well screer. A 26foot bentonite-pellet seal was tremmied into place above the gravel pack, and a 4-foot section of 20-mesh clean silica sand was placed above the bentonite seal. The annular space above the sand was tremmied to approximately 1 foot below land surface witr Volclay grout. 


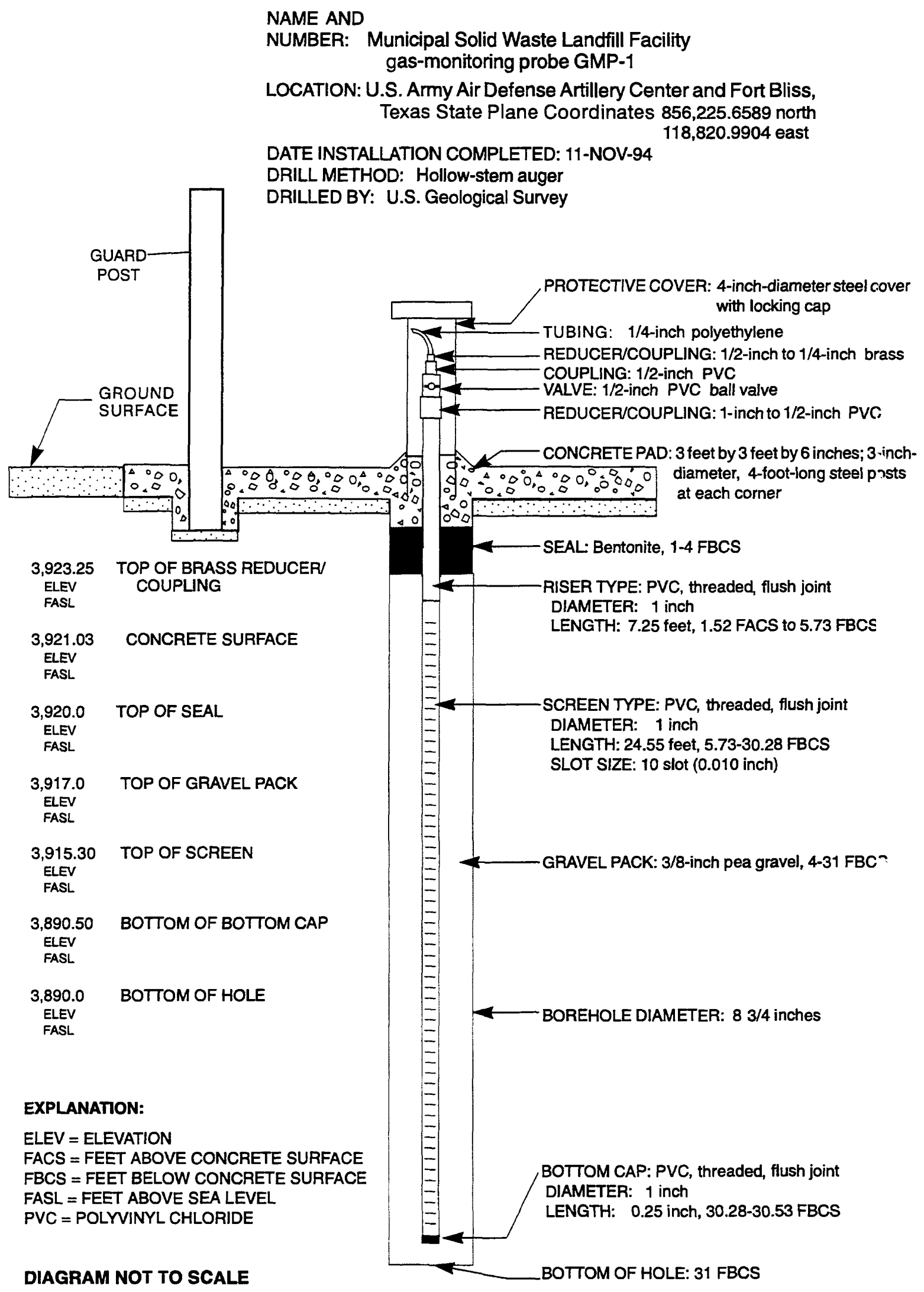

Figure 4.--Completion of gas-monitoring probe GMP-1. 
NAME AND

NUMBER: Municipal Solid Waste Landfill Facility

gas-monitoring probe GMP-2

LOCATION: U.S. Army Air Defense Artillery Center and Fort Bliss,

Texas State Plane Coordinates 856,153.1809 north 119,666.9994 east

DATE INSTALLATION COMPLETED: $12-N O V-94$

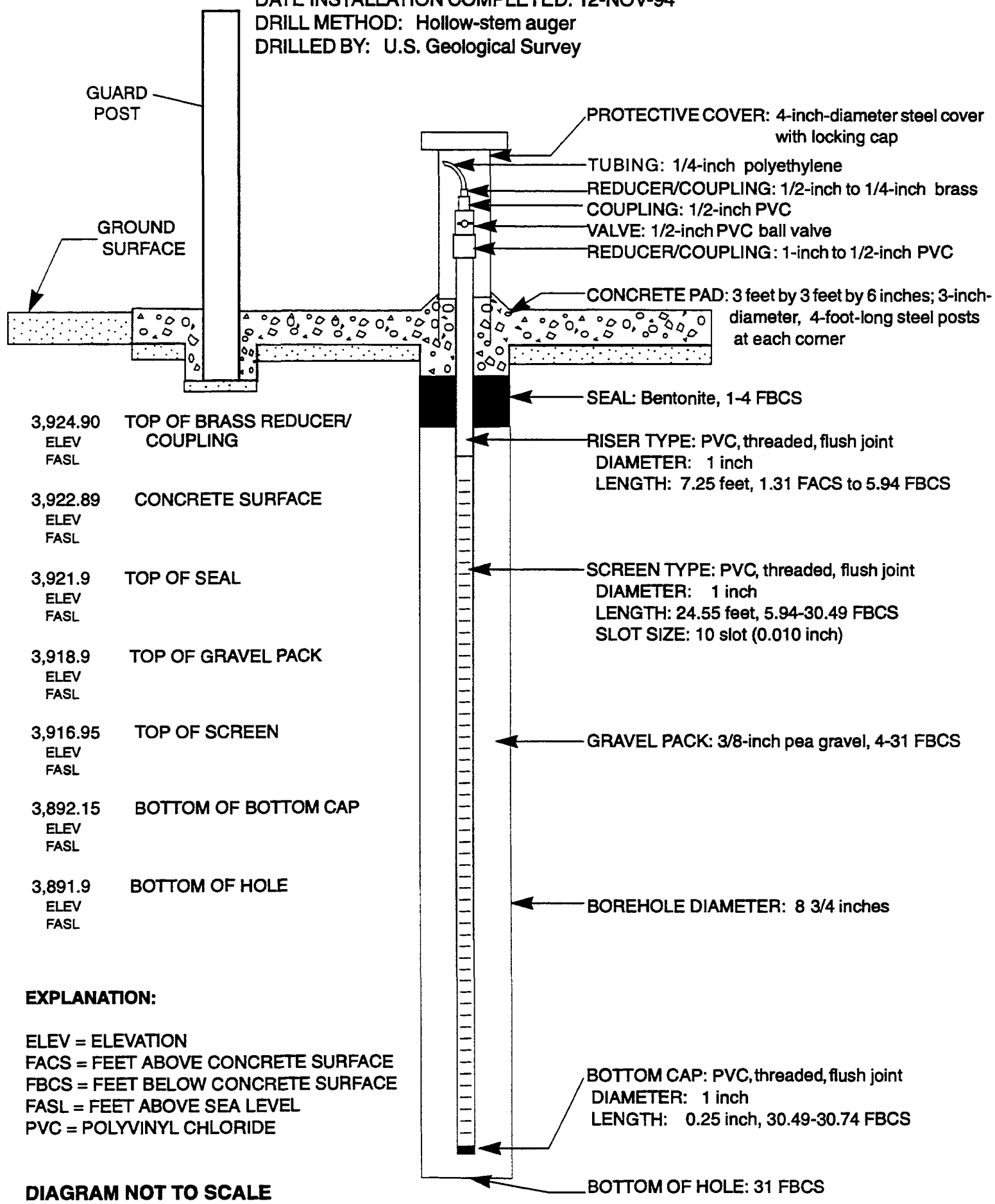

Figure 5.--Completion of gas-monitoring probe GMP-2. 


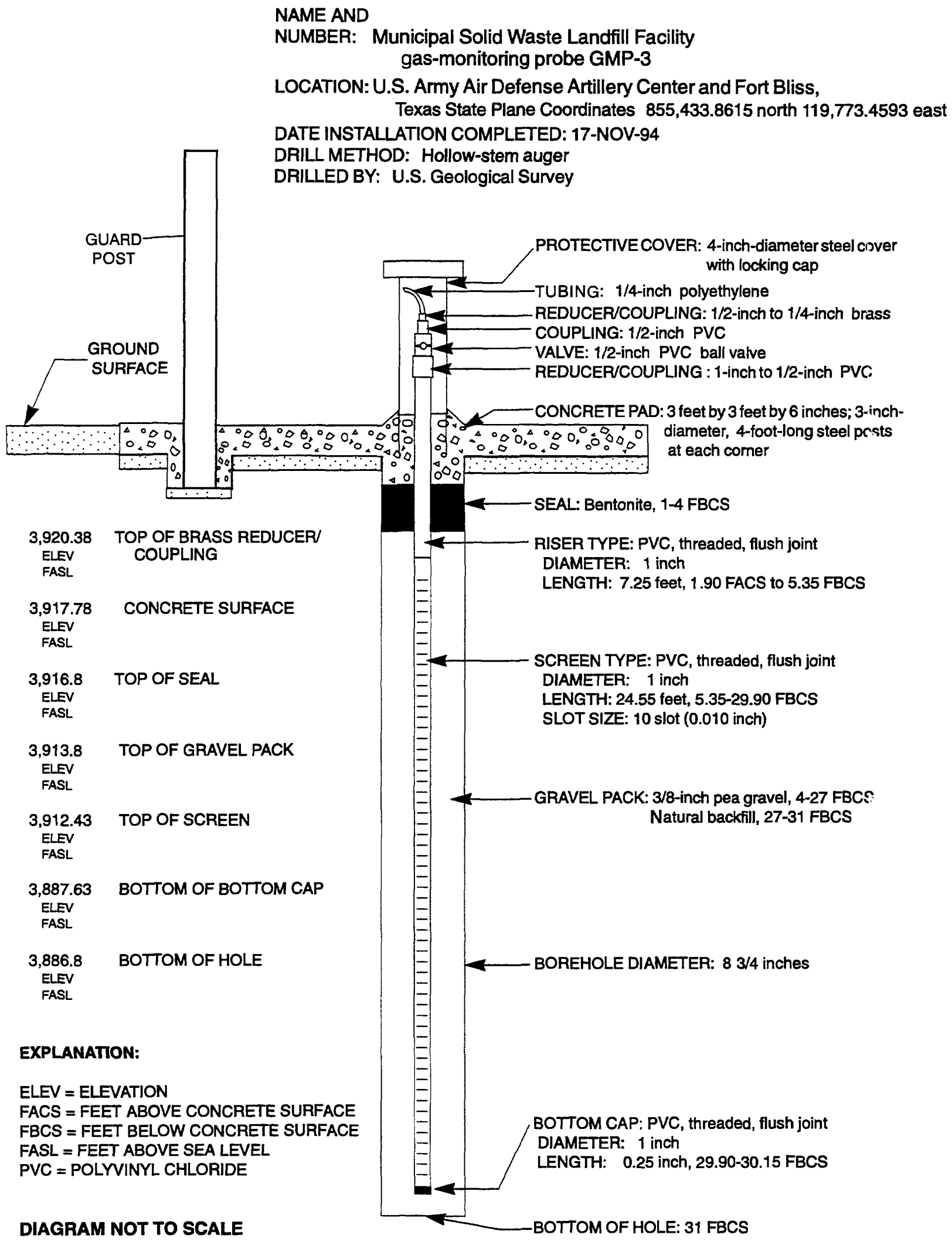

Figure 6.--Completion of gas-monitoring probe GMP-3. 


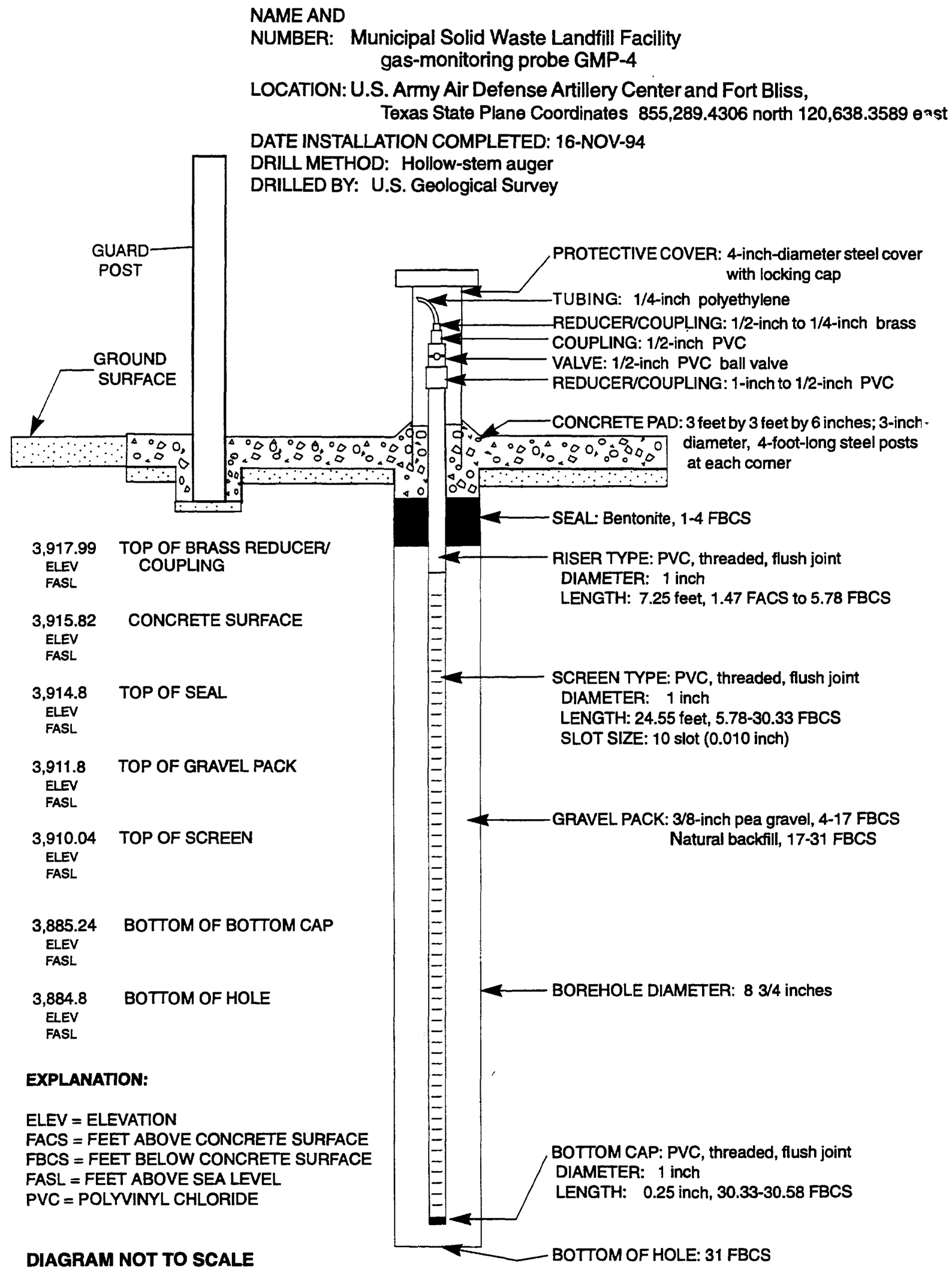

Figure 7.--Completion of gas-monitoring probe GMP-4. 
NAME AND

NUMBER: Municipal Solid Waste Landfill Facility

$$
\text { gas-monitoring probe GMP-5 }
$$

LOCATION: U.S. Army Air Defense Artillery Center and Fort Bliss,

Texas State Plane Coordinates $855,722.2537$ north $121,132.8111$ east

DATE INSTALLATION COMPLETED: $16-N O V-94$

DRILL METHOD: Hollow-stem auger

DRILLED BY: U.S. Geological Survey

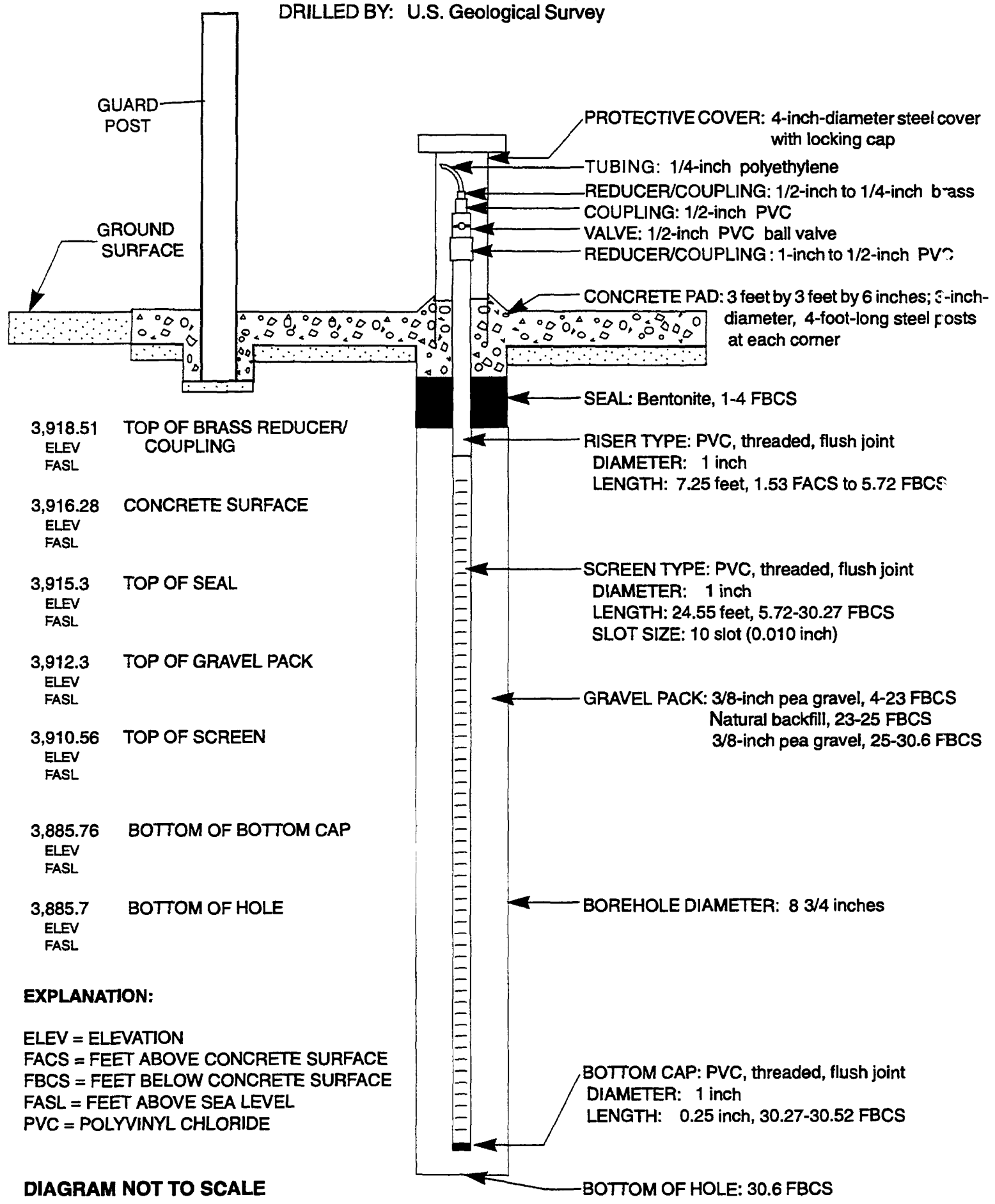

Figure 8.--Completion of gas-monitoring probe GMP-5. 


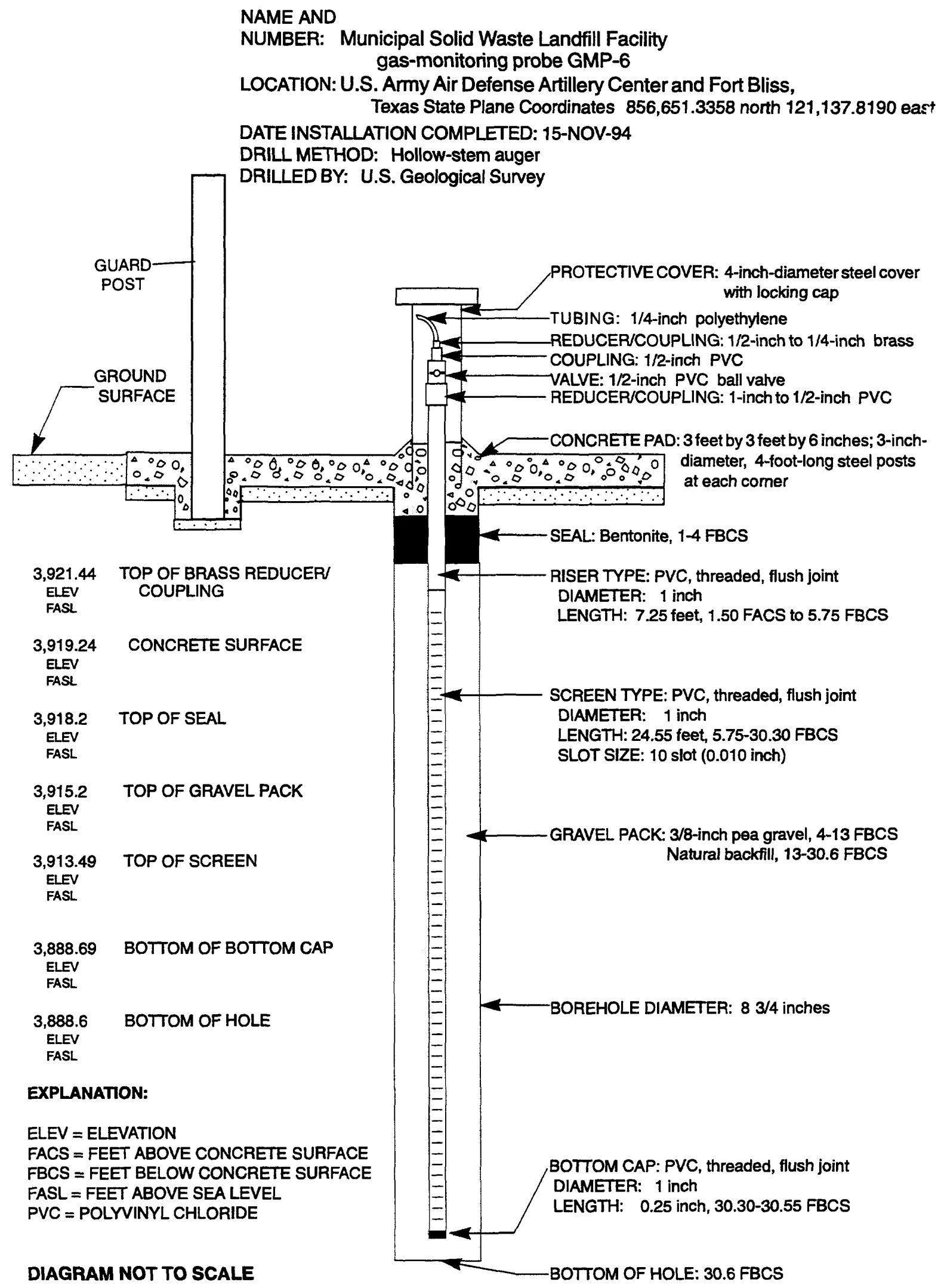

Figure 9.--Completion of gas-monitoring probe GMP-6. 
NAME AND

NUMBER: Municipal Solid Waste Landfill Facility

gas-monitoring probe GMP-7

LOCATION: U.S. Army Air Defense Artillery Center and Fort Bliss, Texas State Plane Coordinates $857,522.5243$ north $121,085.68 \Omega 4$ east

DATE INSTALLATION COMPLETED: 15-NOV-94

DRILL METHOD: Hollow-stem auger

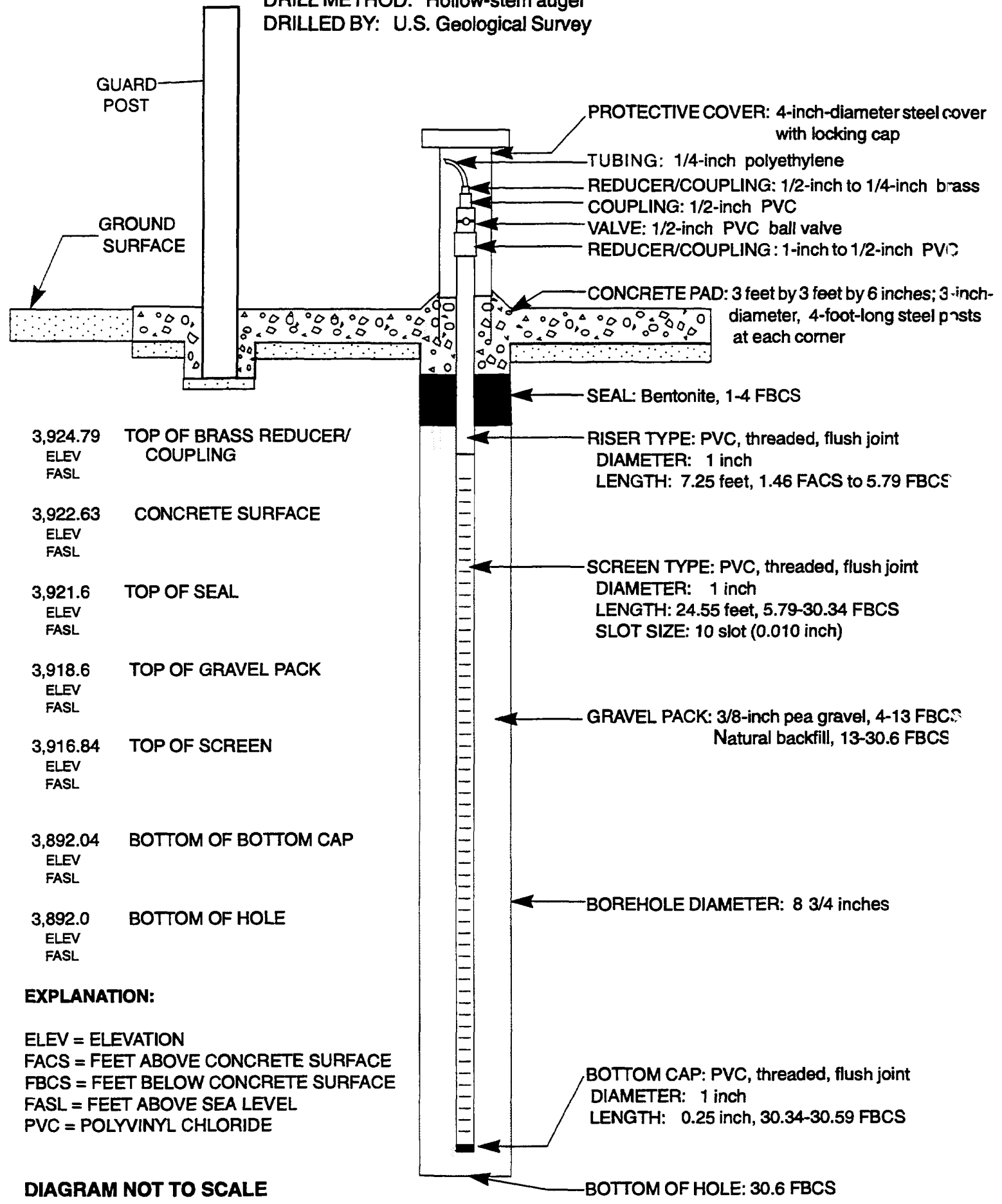

Figure 10.--Completion of gas-monitoring probe GMP-7. 


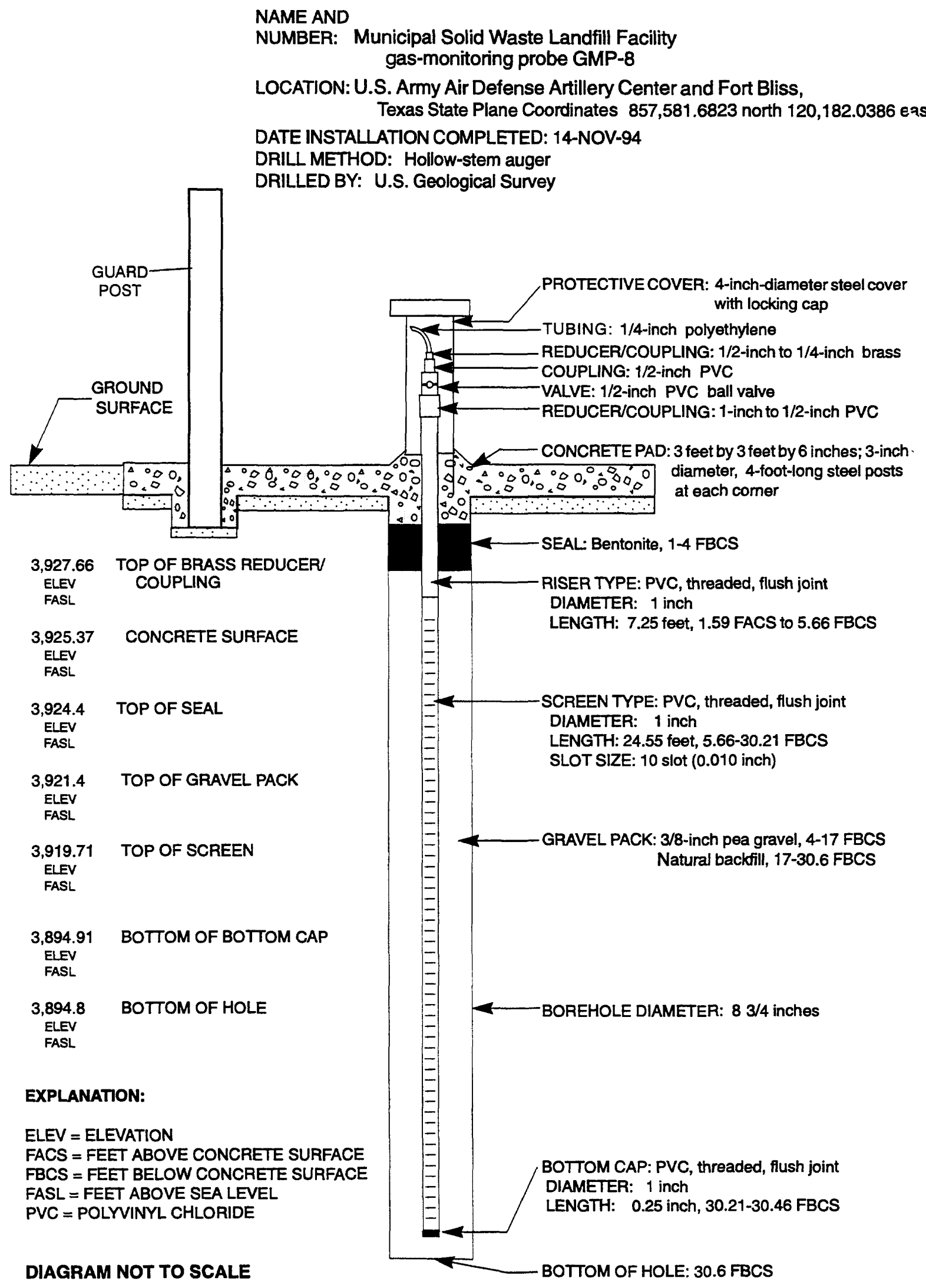

Figure 11.--Completion of gas-monitoring probe GMP-8. 


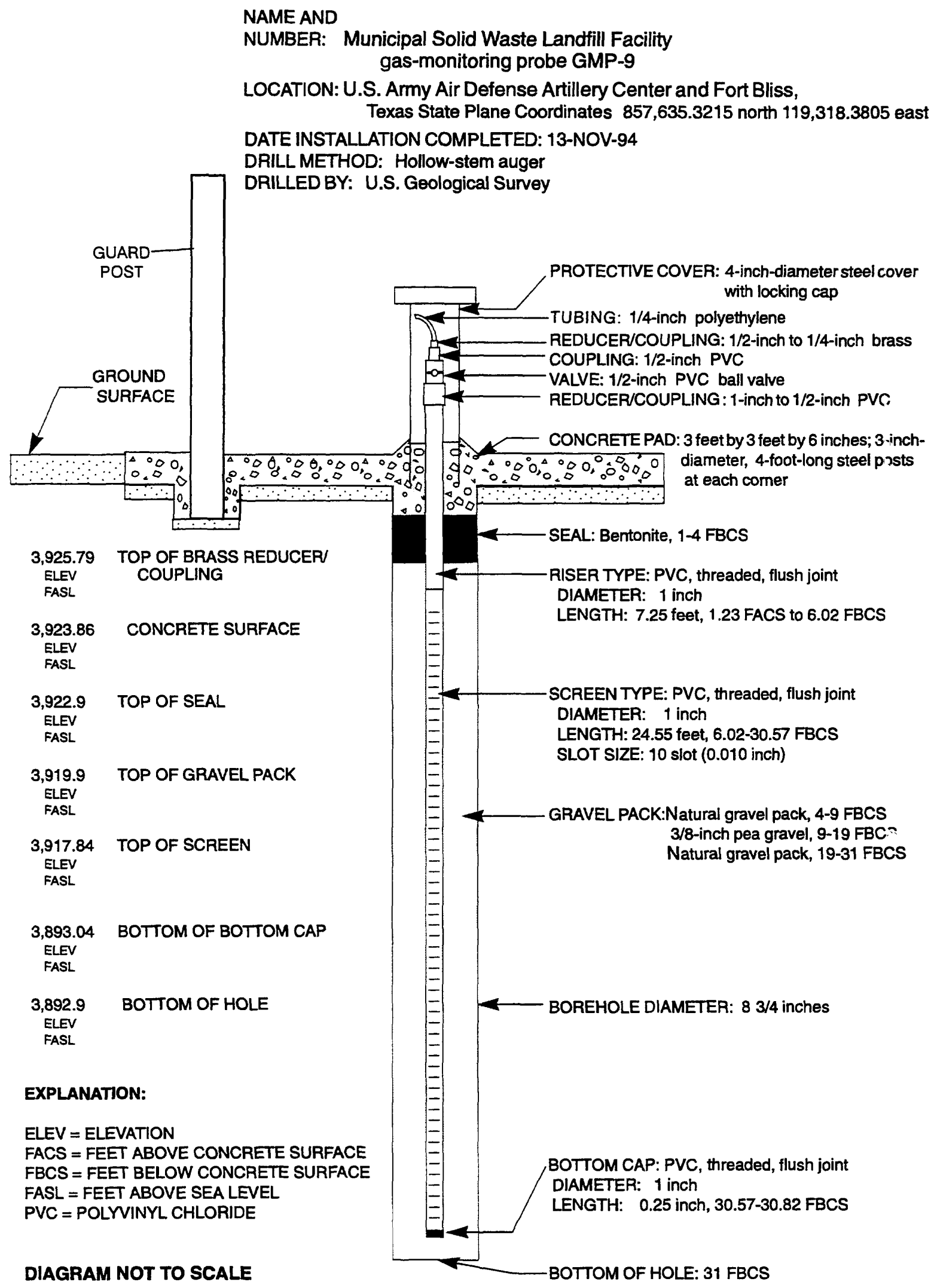

Figure 12.--Completion of gas-monitoring probe GMP-9. 


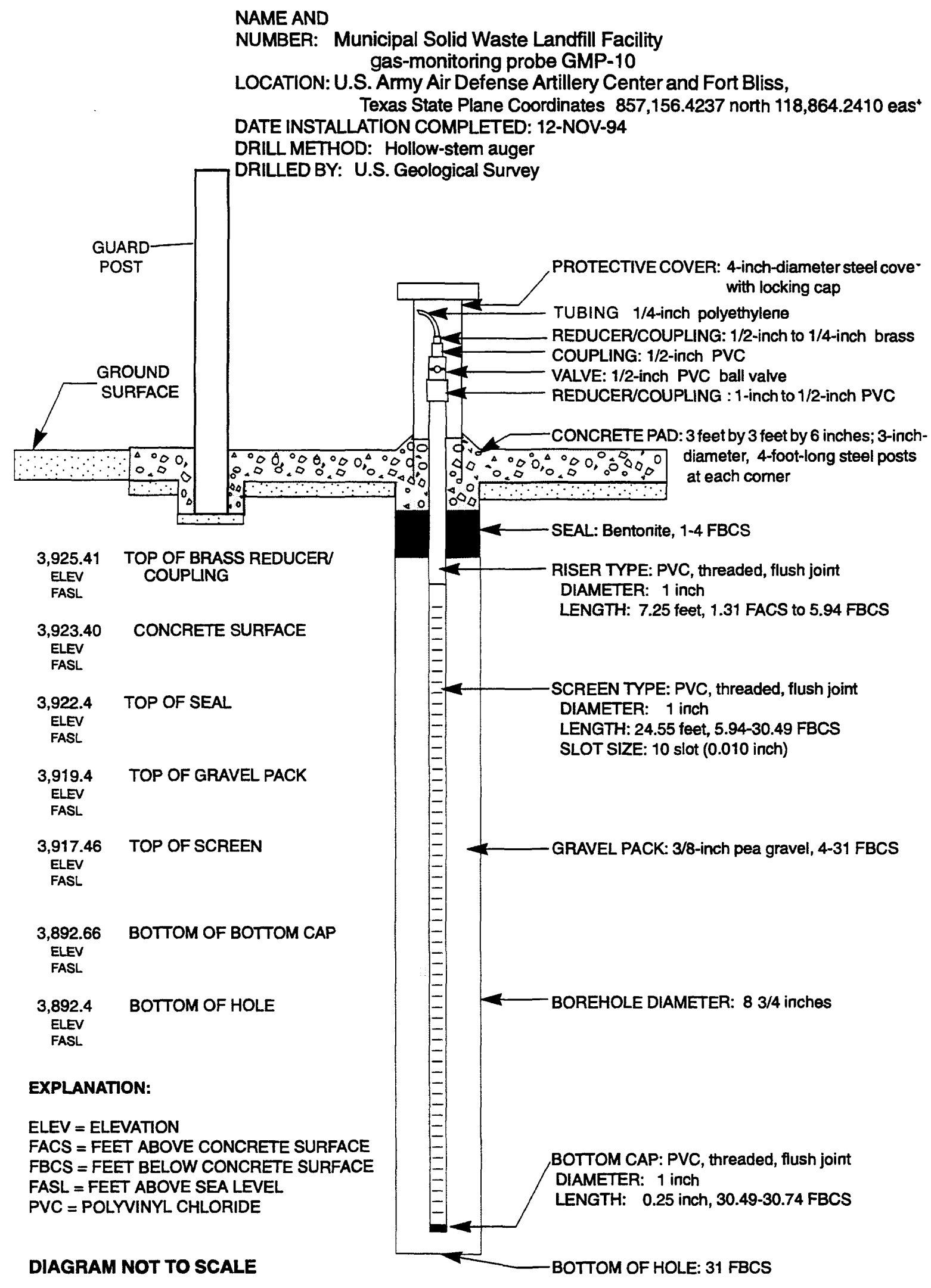

Figure 13.--Completion of gas-monitoring probe GMP-10. 


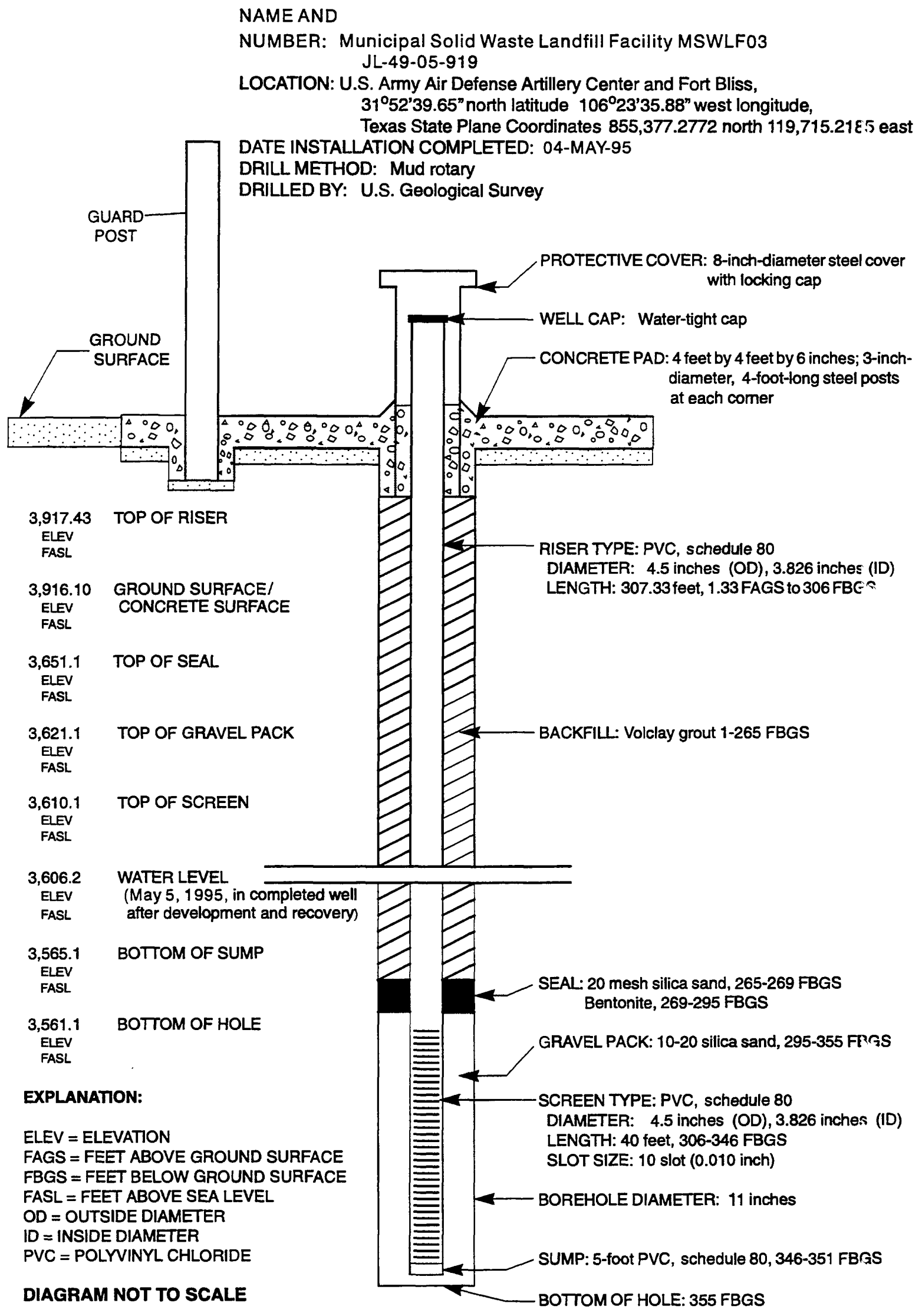

Figure 14.--Completion of ground-water monitoring well MSWLF03. 
After the Volclay grout was allowed to settle overnight, the well was developed by surging it with compressed air until the water removed from the well was relatively clear and free of sediment (approximately 5 hours) and water-quality measurements had stabilized. Water samples collected during the surging process were measured for $\mathrm{pH}$, specific conductance, turbidity, and temperature; these measurements are discussed in the "Ground-water chemical data" section of this report. The water level was measured at 309.9 feet below land surface $(3,606.2$ feet above sea level).

A concrete seal and 4-foot-square by 6-inchthick concrete surface pad with locking steel protective casing was placed on the Volclay grout and around the riser. Four 3-inch-diameter, cement-filled steel guard posts, which extend about 3 feet above the land surface, were placed at each corner of the concrete surface pad (fig. 14).

\section{Soil-Sampling Procedures}

Soil samples collected during drilling of the $\mathrm{BH}-$ 3 and MSWLF03 boreholes were preserved for laboratory analysis of soil chemistry, physical properties, soil-water chloride concentration, and soil moisture. Soil samples also were collected from the landfill cover in the southern area of the landfill (fig. 3).

Soil samples for soil-chemistry analysis were collected from borehole BH-3 at depths of 5, 20, and 50 feet below land surface. The stainless steel split-spoon sampler was pushed into the undisturbed 2-foot interval bracketing the sampling depth. The sampler was retrieved and opened, and the soil samples were immediately collected. Soil samples for analysis of volatile organic compounds and soil moisture were collected first, followed by collection of soil samples for nonvolatile analysis. The quality-assurance/ quality-control (QA/QC) criteria (Sampling and analysis plan for ground-water monitoring at the Municipal Solid Waste Landfill Facility, U.S. Army Air Defense Artillery Center and Fort Bliss, El Paso, Texas, U.S. Geological Survey, written commun., March 1995) for the field-sampling and laboratory procedures included collection of (1) one equipment blank; (2) one duplicate soil sample (collected with the soil sample collected at 50 feet); (3) one ambientconditions blank; (4) one trip blank; (5) one matrixspike (MS) sample; and (6) one matrix-spike duplicate (MSD) sample. The equipment blank was collected by running American Society of Testing and Materials (ASTM) Type II reagent water through the decontaminated split-sampling barrel and catching it in the appropriate sampling bottles. The duplicate soil sample was collected immediately after collention of the environmental sample. The ambient-conditions blank was prepared on site using ASTM Type II reagent water; a bottle of ASTM Type II water was left open at the sampling location and then poured into a sample bottle after its respective environmental, duplicate, MS, and MSD samples were collected. The trip blank was prepared using ASTM Type II reagent water shipped to the site with the sample bottles and was handled as a sample. The MS/MSD samf'es were collected at the 50-foot sample interval immetiately after the respective environmental and duplic te sample bottles were filled. Collection procedures for MS/MSD samples were identical to those for the environmental and replicate samples. The filled and preserved MS/MSD sample bottles were sent to the laboratory where they were spiked with known concentrations of analytes. Analytical results of these samples are presented in the "Soil-chemical cata" section of this report.

Soil samples for analysis of physical properties were collected at various intervals to 55 feet in borehole BH-3 and to 318.5 feet in borehole MSWLF03. A total of 27 soil samples from the recovered cores were collected for laboratory analysis. Twenty-five of the samples were collected frcm the unsaturated zone (above 306-foot depth); the lower two samples were collected from the saturated zon: (below 306-foot depth). With the hollow-stem auger drilling technique, 6 -inch-long by 3.5 -inch-diameter stainless steel tubes were placed in the split-spoon sampler, and the cores (soil samples) were collected directly into the tubes. When the split-spoon sampler was brought to the surface and opened, the tubes were removed from the sampler and plastic end caps were placed on ench end. Electrical tape was wrapped around the cap/tithe junction to provide a more secure seal to preserve the moisture content of the samples. With the mut-rotary drilling technique, the core (soil sample) was removed from the split-spoon sampler and placed into split PVC pipe that was about 6 to 8 inches long and approximately the same diameter as the core. The split PVC pipe was capped with plastic end caps, taned with fiberglass filament tape to keep the two split halves together, and sealed with electrical tape at the cap/PVC junction and along split seams to prevent moisture loss. 
After each soil sample was collected, it was marked with identifying information and packed with paper or bubble pack in an insulated container to avoid wide temperature fluctuations and mechanical damage. Each insulated container contained a wet sponge to maintain a high humidity and was kept shaded as much as possible until delivered to the laboratory. At the laboratory, the cores stored in PVC were subsampled by pressing smaller brass tubes into the core (Daniel B. Stephens and Assoc., Albuquerque, N. Mex., written commun., 1995). Analytical results of these samples are presented in the "Physical properties, total organic carbon, and $\mathrm{pH}$ of soil and sediment samples" section of this report.

Soil samples for analysis of soil-water chloride concentration and soil moisture were collected at approximately 1-foot intervals to 55 feet. At times core recovery was not 100 percent; in these cases, the lost core was assumed to be from the bottom of the interval. Samples were taken from the center of the core using a stainless steel spoon. The outer part of the core was trimmed away to avoid, as much as possible, the effects of moisture migration that might result from heat produced by the auger bit. The samples were placed in 4-ounce glass jars with metal screw-on lids with a composite rubber seal. After the lids were screwed on tightly, plastic electrical tape was wrapped around the jar and lid to help prevent moisture loss from the sample. The samples were then placed in an insulated container with a wet sponge to maintain high humidity and kept in the shade. Analytical results of these samples are presented in the "Soil-water chloride and soil-moisture data" section of this report.

During October 1995, hydraulic conductivity of the landfill cover was determined by an infiltrometer technique (Ankeny, 1992). Hydrologic properties of the landfill cover were measured at five sites (fig. 3). At each site, in situ infiltration was measured at two places about 50 feet apart. After each infiltration measurement was made, a soil core was collected by forcing a brass tube into the moistened soil. The brass tubes filled with soil were capped, taken to the laboratory, and tested for porosity and for percentage of water retained at field capacity and wilting point. Analytical results of these samples are presented in the "Physical properties, total organic carbon, and pH of soil and sediment samples" section of this report.

\section{Lithologic Description of Cores and Cuttings}

The lithology for cores and cuttings from boreholes GMP-1 through GMP-10, BH-3, and MSWLF03 were described using a standard format that allowed consistent, comprehensive recording of the data. The format used included:

-Name of unconsolidated sediment (fig. 15)

-Texture

Grain-size distribution (American Geological Institute, 1989, data sheet 29.1), particle shape (Compton, 1962), sorting (Compton, 1962), grading and packing (American Geological Institute, 1989, data sheets 23.1 and 23.2), and fabric

-Composition of larger grained sediments Mineralogy

- Color

Rock-Color Chart (National Researcl Council, 1948)

-Sedimentary structures

Laminations, microfaults, or other dircernible structures

-Degree of consolidation and cementation, presence of caliche or calcium carborate, reaction with 10 percent hydrochloric acid $(\mathrm{HCl})$

Loosely, moderately, or strongly com nacted; weakly, moderately, or strongly cemented; weak, moderate, or strong reaction with $\mathrm{HCl}$

-Qualitative moisture content Dry, moist, wet, or saturated

-Description of basal contact Abrupt or gradational basal contact

Lithologic descriptors were limited to those readily visible to the eye or with the use of a $10 \mathrm{X}$ hand lens. Made by a USGS hydrologist trained in lithologic description, the descriptions are presented in tables 112 and plate 1 (all tables are in the back of the report)

In addition to lithologic descriptions, field observations were made of depth, core recovery, hole collapse and presence of backfill material, fielt or drilling conditions that affected the collection of cores or cuttings, changes in drilling procedures, an 1 mud weight and viscosity. 
Naming of Unconsolidated Sediments

\begin{tabular}{|c|c|c|c|c|}
\hline & \multicolumn{4}{|c|}{ Main particle } \\
\hline & Gravel & Sand & Silt & Clay \\
\hline Greater than 15 percent gravel & Gravel & Gravelly sand & Gravelly silt & Gravelly clay \\
\hline Greater than 15 percent sand & Sandy gravel & Sand & Sandy silt & Sandy clay \\
\hline Greater than 15 percent silt & Silty gravel & Silty sand & Silt & Silty clay \\
\hline Greater than 15 percent clay & Clayey gravel & Clayey sand & Clayey silt & Clay \\
\hline $5-15$ percent gravel & Not applicable & Sand with gravel & Silt with gravel & Clay with gravel \\
\hline 5-15 percent sand & Gravel with sand & Not applicable & Silt with sand & Clay with sand \\
\hline 5-15 percent silt & Gravel with silt & Sand with silt & Not applicable & Clay with silt \\
\hline 5-15 percent clay & Gravel with clay & Sand with clay & Silt with clay & Not applicable \\
\hline $\begin{array}{l}\text { Greater than } 15 \text { percent gravel } \\
\text { plus greater than } 15 \text { percent sand }\end{array}$ & Sandy gravel & Gravelly sand & $\begin{array}{l}\text { Gravelly sandy } \\
\text { silt }\end{array}$ & $\begin{array}{l}\text { Gravelly sandy } \\
\text { clay }\end{array}$ \\
\hline $\begin{array}{l}\text { Greater than } 15 \text { percent gravel } \\
\text { plus greater than } 15 \text { percent silt }\end{array}$ & Silty gravel & $\begin{array}{l}\text { Gravelly silty } \\
\text { sand }\end{array}$ & Gravelly silt & Gravelly silty clay \\
\hline $\begin{array}{l}\text { Greater than } 15 \text { percent gravel } \\
\text { plus greater than } 15 \text { percent clay }\end{array}$ & Clayey gravel & $\begin{array}{l}\text { Gravelly clayey } \\
\text { sand }\end{array}$ & $\begin{array}{l}\text { Gravelly sandy } \\
\text { silt }\end{array}$ & Gravelly clay \\
\hline $\begin{array}{l}\text { Greater than } 15 \text { percent sand } \\
\text { plus greater than } 15 \text { percent silt }\end{array}$ & Silty sandy gravel & Silty sand & Sandy silt & Sandy silty clay \\
\hline $\begin{array}{l}\text { Greater than } 15 \text { percent sand } \\
\text { plus greater than } 15 \text { percent clay }\end{array}$ & $\begin{array}{l}\text { Sandy clayey } \\
\text { gravel }\end{array}$ & Clayey sand & Sandy clayey silt & Sandy clay \\
\hline $\begin{array}{l}\text { Greater than } 15 \text { percent silt } \\
\text { plus greater than } 15 \text { percent clay }\end{array}$ & Silty clayey gravel & Silty clayey sand & Clayey silt & Silty clay \\
\hline
\end{tabular}

Figure 15.--Protocol used in naming of unconsolidated sediments. 


\section{Geophysical Logs}

Geophysical logs were obtained from the open, mud-filled borehole MSWLF03. Types of logs collected include neutron, gamma ray, resistivity (16inch and 64-inch normal), and caliper (three arm). Geophysical logs can be used as an exploratory method to help describe the lithology of drill cores and cuttings where there is little or no recovery and may also be useful in identifying the water table. Selected geophysical logs are presented on plate 1 .

\section{Soil-Gas and Ambient-Air Data}

Soil-gas samples were collected from the 10 GMPs at the MSWLF, and ambient-air samples were collected at four locations inside the MSWLF guard shack (fig. 3). Samples were collected by the USGS on a quarterly basis from December 1994 to September 1995 (four quarters total). The samples were analyzed in the field with a gas-analyzer meter (Landtec model GA-90). Precipitation data, measured at the El Paso International Airport about 4.5 miles southeast of the MSWLF, also were compiled in conjunction with the soil-gas and ambient-air data. Soil-gas and ambient-air sampling and analysis procedures are documented in "Workplan for methane monitoring network at the Municipal Solid Waste Landfill Facility, U.S. Army Air Defense Artillery Center and Fort Bliss, El Paso, Texas, Final" (U.S. Geological Survey, written commun., November 1994).

Prior to sampling and analysis, the gas analyzer was calibrated according to manufacturer specifications. After the meter was calibrated, barometric pressure and air temperature were measured. Background ambient-air samples were then collected and analyzed for methane, in percent lower explosive limit; methane, in percent by volume; carbon dioxide, in percent by volume; and oxygen, in percent by volume.

After the background measurements were completed, the GMPs were purged, and soil-gas samples were collected and analyzed directly with the gas-analyzer meter. Procedures for sampling each GMP included measuring the probe pressure before pumping; purging the GMP of three well volumes (approximately 20 minutes pumping time at the pumping rate of about 700 cubic centimeters per minute) or until the gas-analyzer readings stabilized (minimum purge of 1 minute); allowing the GMP to recover; measuring barometric pressure and air temperature; and collecting and analyzing the sample. Each soil-gas sample was analyzed for methane, in percent lower explosive limit; methane, in percent by volume; carbon dioxide, in percent by volume; and oxygen, in percent by volume. Gas temperature also was measured during the sampling process.

After the GMPs were sampled and analyzed, ambient-air samples were collected and analyzed at four locations within the MSWLF guard shac ${ }^{1}$ (fig. 3). The ambient-air samples were collected from a linear scan with the gas-analyzer meter within 5 feet of each wall inside the guard shack. These samples wrere analyzed for methane, in percent lower explosive limit; methane, in percent by volume; carbon dioxide, in percent by volume; and oxygen, in percent by volume. Barometric pressure and air temperature also were measured. Soil-gas and ambient-air data collected from the GMPs and guard shack and precipitation data collected at the El Paso International Airport are presented in tables 13-16.

\section{Soil-Chemical Data}

Soil samples collected from borehole $\mathrm{EH}-3$ at depths of 5, 20, and 50 feet below land surface, described in the "Soil-sampling procedures" s.ction of this report, were submitted to Quanterra Environmental Services, Arvada, Colo., for chemical analysic. Soilchemical data for soil samples collected from borehole $\mathrm{BH}-3$ are presented in table 17; associated da $\mathrm{a}$ qualifier codes are presented in table 18. QA/QC and review of analytical data are further discussed in the "Quality assurance/quality control and review' of analytical data" section of this report.

\section{HYDROLOGIC DATA}

Hydrologic data were compiled from (1) soil and sediment samples collected at or adjacent to the MSWLF during the drilling of boreholes $\mathrm{BH}-3$ and MSWLF03, (2) samples collected from the landfill cover over the older part of the MSWLF, and (3) water samples collected from ground-water monitoring well MSWLF03. These data are presented in the following sections. 


\section{Physical Properties, Total Organic Carbon, and pH of Soil and Sediment Samples}

Twenty-seven soil and sediment samples representative of the 351 -foot cored interval adjacent to the MSWLF were collected from boreholes BH-3 and MSWLF03 and analyzed in the laboratory (Daniel B. Stephens and Associates, Inc., Albuquerque, N. Mex.) for physical properties, total organic carbon, and $\mathrm{pH}$. The 27 samples were analyzed for the following physical properties: initial moisture content, dry bulk density, porosity, saturated hydraulic conductivity, moisture retention percentages at various suction values, calculated parameters for the van Genuchten (van Genuchten, 1980) and Brooks-Corey (Brooks and Corey, 1966) equations relating hydraulic conductivity to saturation, and particle size. Analytical methods used to analyze the samples are presented in table 19; results of the analyses are presented in tables 20-24. The upper 25 samples are representative of the unsaturated zone adjacent to the MSWLF; the lower 2 samples are representative of the saturated zone.

Sample numbers (tables 20-24) indicate depth, in feet, for all samples except numbers MSWLF03-81, MSWLF03-318, and MSWLF03-318.5, which were collected from depths of 79,316 , and 316.5 feet, respectively.

Soil samples were collected at five locations on the landfill cover (fig. 3). The area where the samples were collected is representative of the older part of the landfill cover (the filled area outside the Subtitle D area), which consists of locally derived materials. Soil samples collected from the landfill cover were analyzed in the laboratory (Daniel B. Stephens and Associates, Inc., Albuquerque, N. Mex.) for the following physical properties: initial moisture content, dry bulk density, porosity, and moisture retention percentages at various suction values.

In situ infiltration rates were measured in the landfill cover at the same location where the soil samples were collected. Values for saturated and unsaturated hydraulic conductivity were derived from in situ infiltration rate data. Methods used to analyze the landfill-cover samples and in situ measurements are presented in table 25 ; results of the analyses are presented in tables $26-28$.

\section{Soil-Water Chloride and Soil-Moisture Data}

Fifty-eight soil samples were collected for soilwater chloride and soil-moisture analysis (tab'. 29). Samples from 2 to 55 feet were collected from core recovered during the drilling of borehole $\mathrm{BH}-3$ using hollow-stem auger drilling techniques. Samples from 92 to 325 feet were collected from core recovired during the drilling of borehole MSWLF03 using mudrotary drilling techniques. Samples were taken from near the axis of the core using the procedure described in the "Soil-sampling procedures" section of this report.

In the laboratory, the tape was removed from the sample jars, any dirt or adhesive was removed from the exterior, and the jars were weighed (sample weight 1) immediately. Then the lids were removed and the sample, including jar and lid, was oven dried at 105107 degrees Celsius for 24 hours. Some unuse.d containers were weighed and oven baked to assure that weight loss could not be attributed to changes to the rubber seal that might result from the baking. After oven drying, the samples were weighed again (sample weight 2) and the weight loss was attributed to moisture content. A measured weight of deiorized water (about 60 grams) was then added to eack jar and the jars were agitated for 8 hours (McGurk and Stone, 1985, p. 15) to redissolve the chloride. The rerulting solution was extracted and the chloride concentration was measured by USGS personnel using a chloride electrode (Orion model 95-17B) and the instructions of the electrode manufacturer.

Soil-water chloride concentration was calculated as:

$$
C_{s w}=C_{e x t} \cdot V_{d i} / V_{s}
$$

where $\quad \mathrm{C}_{s w}=$ chloride concentration of soil water, in milligrams per liter;

$\mathrm{C}_{\text {ext }}=$ chloride concentration of extract, in milligrams per liter;

$\mathrm{V}_{d i}=$ volume of deionized water atded to the sample, in milliliters; and

$V_{s w}=$ volume of soil water in the s'mple, in milliliters.

After the chloride analyses were completed, the jars were emptied and the jars and lids were cleaned and tared; tare weights were subtracted from sample weight 2 to determine dry soil weights. The gravimetric 
moisture content is equal to the soil-water weight divided by the dry soil weight. The volumetric moisture content is defined by the following equation:

$$
S M_{v}=S M_{g} \cdot \rho_{s} / \rho_{w}
$$

where

$$
\begin{aligned}
& S M_{v}=\text { volumetric moisture content, in } \\
& \text { grams per cubic centimeter; } \\
& S M_{g}=\text { gravimetric soil moisture, in grams } \\
& \text { per gram; } \\
& \rho_{s}=\text { bulk density of sample, in grams per } \\
& \text { cubic centimeter; and } \\
& \rho_{w}=\text { density of water, in grams per cubic } \\
& \text { centimeter. }
\end{aligned}
$$

Soil dry bulk density was as reported by Daniel B. Stephens for samples collected at the same depth as those collected for physical-property analysis. For chloride samples collected at intermediate depths, the dry bulk density was estimated by interpolation.

\section{Depth to Ground Water}

The primary source of ground water in the vicinity of the MSWLF is the unconsolidated and semiconsolidated sedimentary deposits of the Hueco Bolson. Wells completed in the Hueco Bolson supply water for the City of El Paso, Ciudad Juarez, Fort Bliss Military Reservation (figs. 1-2), private industries, and agricultural areas. Wells discharging large amounts of water generally are drilled at least 200 feet into wateryielding material. City of El Paso and Fort Bliss municipal wells completed in the Hueco Bolson range in depth from about 600 to greater than 1,200 feet. Hydraulic characteristics of the Hueco Bolson vary significantly because of the nonuniform nature of the individual beds (Alvarez and Buckner, 1980). On a regional scale the Hueco Bolson can be considered a single aquifer, but on a local scale the rate and volume of water flowing through individual beds probably vary considerably. Hydraulic characteristics of the Hueco Bolson are presented in Abeyta (1996).

On May 5, 1995, depth to water in well MSWLF03 after drilling, development, and recovery was 309.9 feet. On February 19, 1997, depth to water in well MSWLF03 was 315.0 feet.

\section{Ground-Water Chemical Data}

Well MSWLF03 is located hydraulically downgradient from the MSWLF and is assumed to represent the chemistry of ground water moving beneath the MSWLF (Abeyta, 1996, p. 22). A water sample was collected from well MSWLF03 (fig. 3) on February 19, 1997.

Prior to purging and sampling, a water sample from the top of the water column was collecte 1 using a translucent Tefion bailer to examine for the presence of floating hydrocarbons. No visible immiscible layer was observed. Prior to sampling, the well was purged with a stainless steel submersible piston pump (Bennett model 1800-7) with a 500-foot Teflon water-cischarge line. Prior to purging, the pump and discharge line were decontaminated. The outside of the water-discharge line of the sample pump was washed with a solution of potable water and laboratory-grade detergent. The pump and water-discharge line were rinsed with deionized water, and allowed to dry. The pump and inside of the water-discharge line were decontrminated by pumping approximately 35 gallons of deionized water. After decontamination, approximately 8 gallons of ASTM Type II reagent water were pumped through the water-discharge line, then followed by deinnized water to allow collection of the ASTM Type II reagent water for the equipment blank. Compressed nitrogen gas was used to operate the submersible piston pump.

Temperature, turbidity, $\mathrm{pH}$, and specific conductance of the purged ground water were measured periodically during purging until a minimum of 3.5 well volumes of water were removed and the temperature, turbidity, $\mathrm{pH}$, and specific condu-tance had stabilized.

After purging was completed, the well was sampled. Sample bottles for particular analytes were filled in the following order: (1) volatile orgarics, (2) metals, (3) nitrates and common ions, and (4) field properties. Sample bottles were filled from the Teflon discharge line and preserved immediately. Duslicate-, MS, and MSD sample bottles were filled immodiately after their respective environmental samples were collected.

Chain-of-custody procedures were follc wed to ensure that samples were collected, protected, stored, handled, analyzed, and disposed of properly by authorized personnel (Sampling and analysis plan for ground-water monitoring at the Municipal Solid Waste Landfill Facility, U.S. Army Air Defense Artillery Center and Fort Bliss, El Paso, Texas, Final, U.S. Geological Survey, written commun., March 1995). The USGS team leader who collected the sample in the field had initial custody of the samples. The aralytical laboratory, Quanterra Environmental Services, Arvada, Colo., was the ultimate recipient of the samples. 
Purged water from the monitoring wells was stored in 55-gallon steel drums next to the well, classified by USGS personnel according to Title 30 TAC 335 Subchapter $R$, and labeled appropriately. The analytical data for the samples were received and reviewed by USGS staff, and the purged water was determined to be uncontaminated. This determination was based on comparison of analytes identified to U.S. Environmental Protection Agency (EPA)-defined maximum contaminant levels (MCLs) for drinking water (U.S. Environmental Protection Agency, 1994). The purged water was then properly disposed of by USAADACENFB personnel.

\section{Quality Assurance/Quality Control and Review of Analytical Data}

The objective of QA/QC is to monitor the overall sampling program and all environmentally related data collection and analysis to ensure that all data produced are suitable for evaluation and interpretation of groundwater quality at the MSWLF site. Detailed QA objectives and goals for accuracy, precision, completeness, representativeness, and comparability and QC objectives and goals for production and documentation of quality data are defined in the Sampling and analysis plan for ground-water monitoring at the Municipal Solid Waste Landfill Facility, U.S. Army Air Defense Artillery Center and Fort Bliss, El Paso, Texas, Final (U.S. Geological Survey, written commun., March 1995).

The field QA/QC program was developed to ensure and validate that inconsistencies in protocols did not introduce errors into the data-collection process. Field QC checks were used to (1) identify inconsistencies and (2) minimize the potential for interference or introduction of nonenvironmental contaminants during sample collection, storage, transport, and/or equipment decontamination. Applicable QA/QC samples were collected and analyzed during all field sampling activities at the MSWLF site. The following protocols were followed for collection of QA/QC field samples:

Equipment blanks--One was collected per sampling event (soil and water sample collection) and analyzed for the same parameters as the environmental samples. These samples were collected by pumping ASTM Type II reagent water through the sampling equipment (Bennett pump and tubing) and into the appropriate sample bottles. Equipment blanks for soluble metals were run through a filtering apparatus in the field.

Field duplicates--One was collected pesampling event (soil and water sample collection) and analyzed for the same parameters as the environmental samples. Each field-duplicate bottle was filled immediately after its respective environmental sample bottle was filled. Collection procedures for field duplicates were identical to those for the environmental samples.

Matrix spikes and matrix-spike duplicates--One pair was collected per each sampling event (soil and water sample collection). The MS/MSD sample bottles were filled immediately after their respective field-duplicate sample bottles were filled. Collection procedures for MS/ MSD sample bottles were identical to those for the environmental samples. The fillet and preserved MS/MSD sample bottles were sent to the laboratory where they wre spiked with known concentrations of analytes. Each MS/MSD pair was analyzed for the same parameters as its respective environmental sample.

Trip blanks--One trip blank per samplirg event (soil and water sample collection) was prepared for analysis of volatile organic compounds. It was prepared using ASTI 1 Type II reagent water shipped to the site with the sample bottles and handled as a sample.

Ambient-conditions blanks-One ambient-conditions blank per sampling event (soil and water collection) was collected for analysis of volatile organic compounds. It was prepared on site usin? ASTM Type II reagent water. A bottle of the ASTM Type II water was left open at the sampling location and then poured into its respective sample bottle after its respective environmental sample, sample duplicate. MS, and MSD samples were collected.

The accuracy of laboratory $\mathrm{QA} / \mathrm{QC}$ program analytical data was evaluated by the following:

Standard methods that, whenever possible, are recognized and considered as 
standard by the scientific community. EPA methods generally were used.

Calibration standards obtained from the National Institute of Standards and Technology EPA repository or other reliable commercial sources.

Audit samples evaluating laboratory performance on EPA Water Supply and Water Pollution samples to maintain EPA certification.

Surrogate spikes for volatile and semivolatile organic compounds where recovery of organic surrogate analytes should be within three standard deviations of the laboratory-established average recovery of the surrogate analyte.

Known laboratory control samples where recovery of analytes should be within three standard deviations of the laboratoryestablished average recovery of the analyte. For multiple-analyte samples, 80 percent of the analytes should be within control limits. In-house control limits were used.

Recovery of analytes where recovery should be within three standard deviations of the laboratory-established average recovery of the analyte. For multipleanalyte methods, 95 percent of the analytes should be within control limits.

The precision of analytical data was evaluated by submitting duplicate/environmental, MS, and MSD samples. Analytical results for these samples should be within established control limits as defined in the Sampling and analysis plan for ground-water monitoring at the Municipal Solid Waste Landfill Facility, U.S. Army Air Defense Artillery Center and Fort Bliss, El Paso, Texas, Final (U.S. Geological Survey, written commun., March 1995).

Completeness was evaluated by dividing the number of valid data obtained by the total number of samples analyzed and multiplying by 100 to obtain the percentage of analytical data associated with acceptable QC criteria. If 95 percent or greater of the analytical data were in control, then the sample batch was determined to be in control.

Representativeness of field data was evaluated by (1) use of standard methods of measurement and sample collection; (2) collection of sufficient size or amount of sample; (3) documentation of reasons for use of nonstandard techniques; and (4) adherence to chain-of-custody procedures. Representativeress of laboratory analytical data was evaluated by (I) use of preservation techniques to minimize sample degradation that may occur between sample collection and sample analysis; (2) prescribed holding times; (3) field and laboratory blank analyses to determine whether samples have been contaminated; and (4) use of matrix spikes to determine the presence of matrix effects.

Comparability of field and laboratory measurements was evaluated by using standard methods of measurement and analysis of consistent reporting units. Comparability in the laboratory also was evaluated by traceable materials for calib-ation and QC.

Upon completion of analyses and revierv of analytical and QA/QC results, the laboratory submitted laboratory analytical results reports to the USGS. The data were reviewed, and data that did not meet the QA QC criteria were identified. The USGS submitted laboratory analytical results and $\mathrm{QA} / \mathrm{QC}$ datavalidation results to the USAADACENFB. Th: USAADACENFB reviewed the information and submitted laboratory analytical results reports and QA QC data-validation reports to the TNRCC. These reports are available to the public at the USAADACENFB, Directorate of Environment, El Paso, Texas, and at the TNRCC Records Cent?r, Austin, Texas.

The QA/QC analytical data collected during sampling at the MSWLF site are not presented in this report; they may be reviewed at the locations mentioned above. Environmental-sample data collected February 19, 1997, from the MSWLF ground-water monitoring well are presented ir the following sections of this report. Environmentalsample data that did not meet the QA/QC criteria are still reported in the data table but are qualified. Qualified data are flagged data that may have been noncompliant but were usable.

\section{Results of Analyses}

Water-quality data collected February 19, 1997, for MSWLF03 are presented in table 30; associated data-qualifier codes are presented in table 18. C" amical concentrations detected in water for well MSV/LF03 were below EPA-identified MCLs (table 31) for public drinking-water supplies. 


\section{REFERENCES}

Abeyta, C.G., 1996, Geohydrologic site characterization of the Municipal Solid Waste Landfill Facility, U.S. Army Air Defense Artillery Center and Fort Bliss, El Paso, Texas: U.S. Geological Survey Water-Resources Investigations Report 95-4217, $36 \mathrm{p}$.

Alvarez, H.J., and Buckner, A.W., 1980, Ground-water development in the El Paso region, Texas, with emphasis on the resources of the lower El Paso Valley: Texas Department of Water Resources Report 246, $346 \mathrm{p}$.

American Geological Institute, 1989, Data sheets for geology in the field, laboratory, and office: American Geological Institute.

American Public Health Association and others, 1985, Standard methods for the examination of water and wastewater (16th ed.): Washington, D.C., American Public Health Association, 1,268 p.

Ankeny, M.D., 1992, Methods and theory for unconfined infiltration measurements, in Advances in measurement of soil physical properties--Bringing theory into practice: Soil Science Society of America Special Publication 30, p. 123-141.

Ankeny, M.D., Ahmed, M., Kaspar, T.C., and Horton, R., 1991, A simple field method for determining unsaturated hydraulic conductivity: Soil Science Society American Journal, v. 55, p. 467-470.

Ankeny, M.D., Kaspar, T.C., and Horton, R., 1988, Design for an automated tension infiltrometer: Soil Science Society American Journal, v. 52, p. 893-896.

1989, Design for an automated tension infiltrometer: U.S. Patent \#4,884,436.

Brooks, R.H., and Corey, A.T., 1966, Properties of porous media affecting fluid flow, in Journal of the Irrigation and Drainage Division: Proceedings of the American Society of Civil Engineers, v. 92, no. IR2, June 1966, p. 61-88.

Compton, R.R., 1962, Manual of field geology: New York, John Wiley and Sons, $378 \mathrm{p}$.

Elrick, D.E., Reynolds, W.D., Baumgartner, N., Tan, K.A., and Bradshaw, K.L., 1988, In situ measurements of hydraulic properties of soils using the Guelph permeameter and the Guelph infiltrometer, in Proceedings of the Third International Workshop on Land Drainage: Columbus, Ohio, December 7-11, 1987.

Klute, A., ed., 1986, Methods of soil analysis, part 1: Madison, Wisc., American Society of Agronomy ( $2 \mathrm{~d}$ ed.).

McGurk, B.E., and Stone, W.J., 1985, Evaluation of laboratory procedures for determining soil-water chloride: Socorro, New Mexico Bureau of Mines and Mineral Resources Open-File Report 215, 33 p.
National Research Council, 1948, Rock-Color Chart: Geological Society of America, 16 p.

Perroux, K.M., and White, I., 1988, Designs for disc permeameters: Soil Science Society American Journal, v. 52, p. 1,205-1,215.

Prieksat, M.A., Ankeny, M.D., and Kaspar, T.C., 1991, Design for an automated single-ring ponded infiltrometer: Soil Science Society American Journal, v. 56, p. $1,409-1,411$.

Texas Natural Resources Conservation Commission, 1993, 30 TAC 330, Municipal solid waste: Texas Register, Austin, Tex., 194 p. plus updates through December 1993.

U.S. Department of Commerce, National Oceanic and Atmospheric Administration, Environmental Data Service, 1992, Annual summary, Texas: National Oceanic and Atmospheric Administration, v. 97, no. 13, $80 \mathrm{p}$.

U.S. Environmental Protection Agency, 1983, Methods for chemical analysis of water and wastes: U.S. Environmental Protection Agency Manual 607/4-79. 020.

1986a, Inductively coupled plasma-atomic emission spectrometer method for trace element analysis of water and wastes: Federal Register, 40 CFR 261, app. C, July 1, 1986.

1986b, Methods for organic chemical analy'sis of municipal and industrial wastewater: Federal Register, 40 CFR 136, app. A, July 1, 1986.

1986c, Test methods for evaluating solid w?ste, physical/chemical methods, SW-846 (3d ed.).

1991, The RETC code for quantifying the $r y$ draulic functions of unsaturated soils: EPA/600/2-91/765, December 1991.

1993, Code of Federal Regulations, Title 40, Environment, Parts 257 and 258, Subtitle D, J"ly 1, 1993.

1994, Summary of EPA finalized national primary drinking water regulations: U.S. Environment 1 Protection Agency, July 1994, 7 p.

1996, Drinking water regulations and health advisories: Washington, D.C., U.S. Environmental Protection Agency, Office of Water, $11 \mathrm{p}$.

van Genuchten, M., 1980, A closed form equation for predicting the hydraulic conductivity of unsat arated soils: Soil Science Society of America Journal, v. 44, p. 892-898.

Wooding, P.A., 1968, Steady infiltration from a shallow circular pond: Water Resources Research, v. 4, p. 1,259-1,273. 
Table 1.--Lithology penetrated by borehole GMP-1

[Color codes are from the Rock-Color Chart (National Research Council, 1948). See figure 15 for protocol used in naming unconsolidated sediments. $\leq$, less than or equal to; $<$, less than;

$\%$, percent; $\mathrm{ft}$, feet; mm, millimeters; $\mathrm{HCl}$, hydrochloric acid]

Lithologic description

Dipth interval

below land

s:urface (feet)

Sand; fine grained, very well sorted, angular to subangular; arkosic with abundant quartz; light brown (5 YR5/6); loose, slight to moderate reaction with $\mathrm{HCl}$; very slightly moist; abrupt basal contact

Sandy silt (caliche); sand--very fine to fine grained, pebbles approximately $1 \%$ and $\leq 35 \mathrm{~mm}$; sand and pebbles-subangular to subrounded, well sorted; sand-quartz with minor feldspar; grayish orange (10 YR7/4); loose to slightly compacted from 4 to $4.5 \mathrm{ft}$, slightly to moderately compacted from 4.5 to $6 \mathrm{ft}$, strong reaction with $\mathrm{HCl}$; dry; gradational basal contact - _ Silty sand with caliche; sand-very fine to fine grained, pebbles $<1 \%$ at top to $3 \%$ at bottom and $\leq 40 \mathrm{~mm}$, well sorted at top to poorly sorted toward bottom; sand-quartz with minor feldspar; pebbles-quartzite, granite; moderately to strongly compacted, caliche abundant as blebs, strong to moderate reaction with $\mathrm{HCl}$; slightly moist to dry

No recovery

$7.2-9$

Sand; sand-fine to medium grained, pebbles $\leq 3 \%$ and $\leq 40 \mathrm{~mm}$; sand-angular, subangular, and subrounded; pebbles--subangular, subrounded, and rounded, moderately well sorted; sand-quartz with minor feldspar; pebbles--sandstone, quartzite, granite; loose, moderate reaction with $\mathrm{HCl}$; slightly moist; abrupt basal contact

Clayey sand; sand-very fine grained, very well sorted; moderate-yellowish-brown (10 YR5/4); moderately compacted, caliche minor and present as blebs, no reaction with $\mathrm{HCl}$, blebs have strong reaction with $\mathrm{HCl}$; slightly moist; abrupt basal contact -

Silty sand; sand-very fine grained, very well sorted; dark yellowish orange (10 YR6/6); 1- to 2-mm laminations; moderately to slightly compacted, no reaction with $\mathrm{HCl}$; slightly moist; gradational basal contact

Clayey silty sand with caliche; sand-very fine grained, well sorted; clayey zones-moderate brown (5 YR4/4); silty sand-moderate-yellowish-brown (10 YR5/4); clay as blebs; moderately compacted, caliche as blebs, no to weak reaction with $\mathrm{HCl}$, caliche has strong reaction with $\mathrm{HCl}$; slightly moist; abrupt basal contact

Sand; sand-very fine to fine grained, pebbles $<1 \%$ and $<45 \mathrm{~mm}$ from 18.1 to $18.6 \mathrm{ft}$; sand--subangular, pebbles-subangular to subrounded, very well to moderately well sorted; sand-arkosic with abundant quartz; pebbles-quartzite, granite; moderate yellowish brown (10 YR5/4); loose, no reaction with $\mathrm{HCl}$; slightly moist; gradational basal contact

Sandy clay; sand--very fine to fine grained, well sorted; moderate brown (5 YR4/4); moderately to strongly compacted, friable, caliche present as blebs, very strong reaction with $\mathrm{HCl}$; slightly moist to moist; abrupt basal contact

Sand; fine to medium grained, grading to medium to very coarse grained toward bottom, pebbles $\leq 0.5 \%$ to $<3 \%$ and $\leq 45 \mathrm{~mm}$ from 23.5 to $31 \mathrm{ft}$; sand-angular to subangular, very well sorted from 22.3 to 23.5 $\mathrm{ft}$, well graded from 23.5 to $31 \mathrm{ft}$; sand--arkosic with abundant quartz; moderate yellowish brown (10 YR5/4); loose, no reaction with $\mathrm{HCl}$; moist to very moist 
Table 2.--Lithology penetrated by borehole GMP-2

[Color codes are from the Rock-Color Chart (National Research Council, 1948). See figure $15 \mathrm{fc}^{-}$ protocol used in naming unconsolidated sediments. $\leq$, less than or equal to; $<$, less than; $\%$, percent; $\mathrm{ft}$, feet; $\mathrm{mm}$, millimeters; $\mathrm{HCl}$, hydrochloric acid; $\mathrm{CaCO}_{3}$, calcium carbonate]

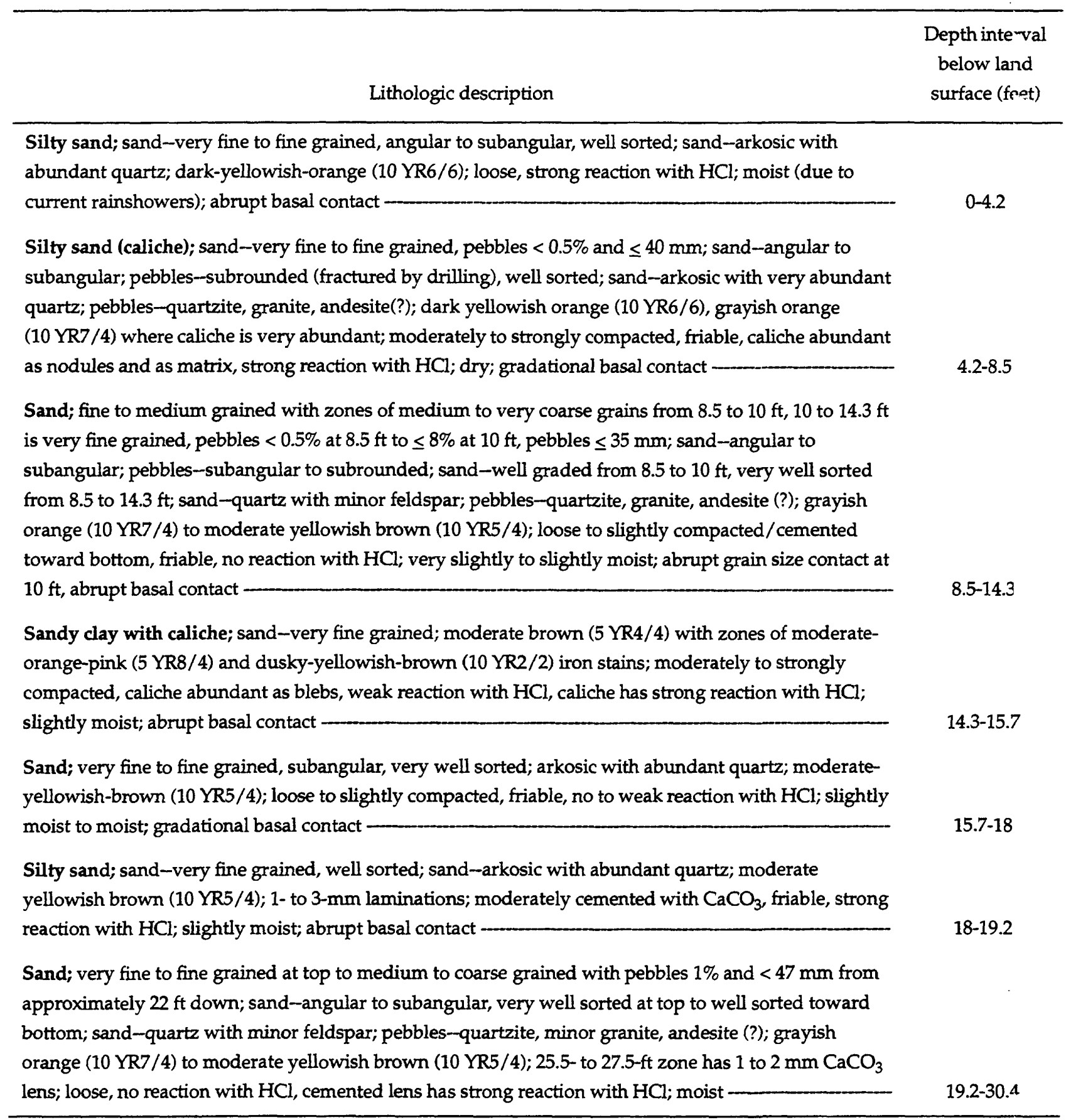


Table 3.--Lithology penetrated by borehole GMP-3

[Color codes are from the Rock-Color Chart (National Research Council, 1948). See figure 15 for protocol used in naming unconsolidated sediments. $\leq$, less than or equal to; $<$, less than;

$\%$, percent; ft, feet; mm, millimeters; $\mathrm{HCl}$, hydrochloric acid]

Lithologic description

Depth interval

holow land

surface (feet)

Silty sand; sand-very fine to fine grained, subangular to subrounded, well sorted; sand-arkosic with abundant quartz; dark-yellowish-orange (10 YR6/6); loose, caliche increasing with depth, weak reaction with $\mathrm{HCl}$ at top to strong reaction with depth; very slightly moist

Silty sand (caliche); sand-very fine to fine grained, well sorted; sand-arkosic with abundant quartz; dark yellowish orange (10 YR6/6) at top to moderate yellowish brown (10 YR5/4) toward bottom; caliche--very pale orange (10 YR8/2); loose (cuttings), moderately to strongly compacted, caliche abundant as blebs, nodules, and matrix, strong reaction with $\mathrm{HCl}$; slightly moist to dry; gradational basal contact

Silty sand; sand-very fine to fine grained, subangular to subrounded, well sorted; sand-arkosic with abundant quartz; 7.6-9.9 ft-light brown (5 YR5/6); 9.9-10.4 ft-light brown (5 YR6/4); 9.9-10.4 ft appears to contain part of a clay nodule; weakly compacted, friable, moderate reaction with $\mathrm{HCl}$; slightly moist -

Sand with silt; sand-very fine grained, well sorted; sand-quartz with minor feldspar and mafics; grayish orange (10 YR7/4); loose, weak to no reaction with $\mathrm{HCl}$; slightly moist; abrupt basal contact -

Sand; very fine to medium grained, subangular to subrounded, well graded; quartz with minor feldspar and mafics, grayish orange (10 YR7/4) to moderate yellowish brown (10 YR5/4); loose, no reaction with $\mathrm{HCl}$; slightly moist to moist

Sand; very fine to fine grained, subangular to subrounded, very well sorted; quartz with very minor feldspar and mafics; grayish orange (10 YR7/4); loose, no reaction with $\mathrm{HCl}$; slightly moist to moist; gradational basal contact

Silty sand; sand-very fine to very coarse grained, pebbles $\leq 1 \%$ and $\leq 25 \mathrm{~mm}$; sand and pebblessubangular to subrounded, poorly sorted; sand-quartz with minor feldspar and mafics; pebblesquartzite, granite, obsidian; moderate yellowish brown (10 YR5/4); moderately compacted/cemented, strong to moderate reaction with $\mathrm{HCl}$; slightly moist to moist; gradational basal contact

Sand with pebbles; sand-very fine to very coarse grained, pebbles $\leq 2 \%$ at top to $\leq 5 \%$ toward bottom, $\leq 15 \%$ in zones and $\leq 50 \mathrm{~mm}$; sand and pebbles-subangular to subrounded; some pebbles-rounded, well graded, very poorly sorted; sand-quartz with minor feldspar and mafics; pebbles--quartzite, feldspar, basalt, sandstone, andesite(?); pale yellowish brown (10 YR6/2) at top to moderate yellowish brown (10 YR5/4) toward bottom; loose, no reaction with $\mathrm{HCl}$; moist 
Table 4.--Lithology penetrated by borehole GMP-4

[Color codes are from the Rock-Color Chart (National Research Council, 1948). See figure 15 foprotocol used in naming unconsolidated sediments. $\leq$, less than or equal to; <, less than;

$\%$, percent; $\mathrm{ft}$, feet; $\mathrm{mm}$, millimeters; $\mathrm{HCl}$, hydrochloric acid]

Depth interval

below land

Lithologic description

surface (fe :t)

Silty sand; sand-very fine to fine grained, subangular to subrounded, well sorted; sand-arkosic with abundant quartz and equal but lesser amounts of feldspar and mafics; moderate yellowish brown (10 YR5/4) to light brown (5 YR5/6); loose, moderate to strong reaction with $\mathrm{HCl}$; slightly moist

Silty sand (caliche) grading to sandy silt; silt more abundant than at 0 to $2 \mathrm{ft}$; sand-very fine to fine grained, subangular to subrounded; well sorted sand-arkosic with abundant quartz and equal but lesser amounts of feldspar and mafics; light brown (5 YR6/4); caliche-very pale orange (10 YR8/2), moderate yellowish brown (10 YR5/4) near bottom; loose to powdery, slightly compacted toward bottom, caliche abundant as nodules, moderate to strong reaction with $\mathrm{HCl}$; slightly moist; gradational basal contact

Silty sand; sand-very fine to fine grained, subangular to subrounded, well sorted; sand-arkosic with abundant quartz; light brown (5 YR5/6); caliche-very pale orange (10 YR8/2); moderately compacted, caliche abundant as veins and as blebs in lower $1.3 \mathrm{ft}$, weak reaction with $\mathrm{HCl}$, caliche has strong reaction with $\mathrm{HCl}$; slightly moist; gradational basal contact

Sand; sand-very fine to fine grained to approximately $25 \mathrm{ft}$, very fine to very coarse grained from 25 to $30.4 \mathrm{ft}, 20$ to $25 \mathrm{ft}$ has $0.2-\mathrm{ft}$ zone with pebbles $<3 \%$ and $\leq 40 \mathrm{~mm}$; sand and pebbles-subangular to subrounded, very well sorted to $25 \mathrm{ft}$, well graded from 25 to $30.4 \mathrm{ft}$; sand-quartz, also minor feldspar and mafics from 20 to $30.4 \mathrm{ft}$; pebbles-quartzite; $9.9 \mathrm{ft}$ to approximately $20 \mathrm{ft}$-dark yellowish orange (10 YR6/6) to moderate yellowish orange (10 YR5/4); 20-25 ft-pale yellowish brown (10 YR6/2); 25-30.4 ft-grayish orange ( $10 \mathrm{YR7} / 4$ ); loose, 11 to $12 \mathrm{ft}$ contains some caliche and has moderate to strong reaction with $\mathrm{HCl}$, otherwise no to weak reaction with $\mathrm{HCl}$; slightly moist at top to slightly moist to moist toward bottom 
Table 5.--Lithology penetrated by borehole GMP-5

[Color codes are from the Rock-Color Chart (National Research Council, 1948). See figure 15 for protocol used in naming unconsolidated sediments. $\leq$, less than or equal to; <, less than;

$\%$, percent; $\mathrm{ft}$, feet; $\mathrm{mm}$, millimeters; $\mathrm{HCl}$, hydrochloric acid]

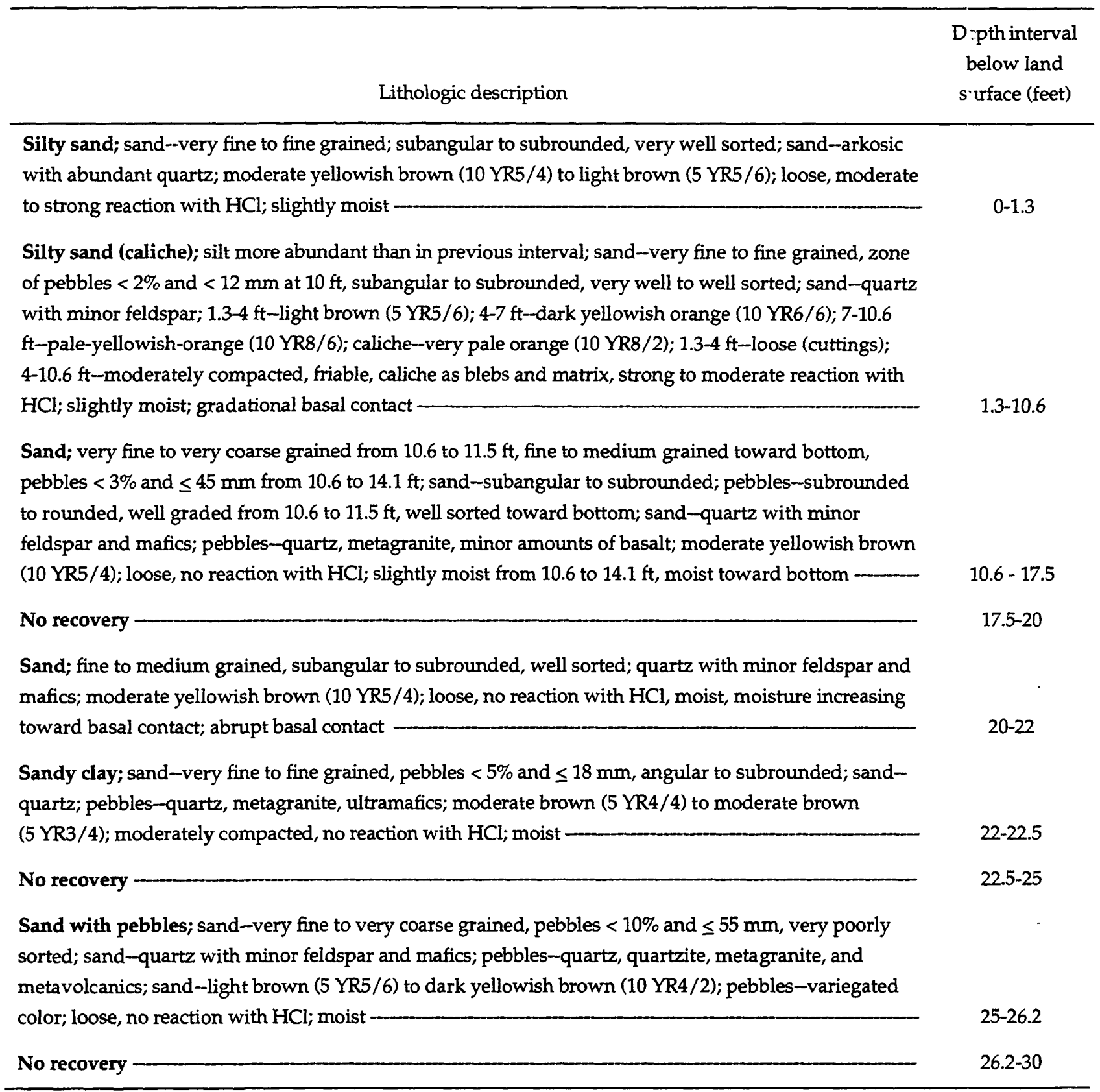


Table 6.--Lithology penetrated by borehole GMP-6

[Color codes are from the Rock-Color Chart (National Research Council, 1948). See figure 15 for protocol used in naming unconsolidated sediments. $\leq$, less than or equal to; $<$, less than;

$\%$, percent; ft, feet; mm, millimeters; $\mathrm{HCl}$, hydrochloric acid]

$\begin{array}{cc} & \text { Depth interval } \\ & \text { below land } \\ \text { Lithologic description } & \text { surface (feet) }\end{array}$

Silty sand; sand--very fine to fine grained with < $2 \%$ coarse grains; sand--subangular to subrounded, very well sorted; sand-arkosic with abundant quartz; moderate yellowish brown (10 YR5/4) to light brown (5 YR5/6); loose, moderate to strong reaction with $\mathrm{HCl}$; slightly moist

Silty sand (caliche); silt more abundant than above section; sand-very fine to fine grained, sand-subangular to subrounded, very well to well sorted; sand--arkosic with abundant quartz; light brown (5 YR6 /4) to moderate orange pink (5 YR8/4); caliche-very pale orange (10 YR8/2); loose (cuttings) to moderately compacted, friable, caliche as blebs, strong to moderate reaction with $\mathrm{HCl}$; slightly moist; abrupt basal contact

(Caliche) silty sand; sand-very fine to fine grained; sand-subangular to subrounded, very well to well sorted; sand-arkosic with abundant quartz; very pale orange (10 YR8/2) to grayish orange (10 YR7/4); moderately compacted, caliche dominant as large blebs, strong reaction with $\mathrm{HCl}$; slightly moist; abrupt basal contact

Silty sand; sand--very fine to fine grained, very well sorted; sand-quartz with minor feldspar and mafics; pale yellowish orange (10 YR8/6) to dark yellowish orange (10 YR6/6); loose, moderate to strong reaction with $\mathrm{HCl}$; slightly moist; gradational basal contact

Clayey sand; sand--very fine to fine grained; sand-subrounded to rounded, very well sorted; sand-quartz with feldspar; grayish orange (10 YR7/4) to light brown (5 YR6/4); moderately compacted, friable, moderate reaction with $\mathrm{HCl}$; slightly moist; abrupt basal contact

Sand; very fine to fine grained, pebbles $<2 \%$ and $<40 \mathrm{~mm}$ from 14 to $19.5 \mathrm{ft}$, subangular to subrounded; pebbles--subrounded to rounded; sand--very well sorted; pebbles-poorly sorted; sand-quartz with minor feldspar and mafics, feldspar decreasing toward bottom while mafics increase; pebbles-quartzite, granite, sandstone; grayish orange (10 YR7/4) to dark yellowish orange (10 YR6/6); loose, weak to no reaction with $\mathrm{HCl}$; moist 


\section{Table 7.--Lithology penetrated by borehole GMP-7}

[Color codes are from the Rock-Color Chart (National Research Council, 1948). See figure 15 for protocol used in naming unconsolidated sediments. $\mathrm{ft}$, feet; $\mathrm{HCl}$, hydrochloric acid]

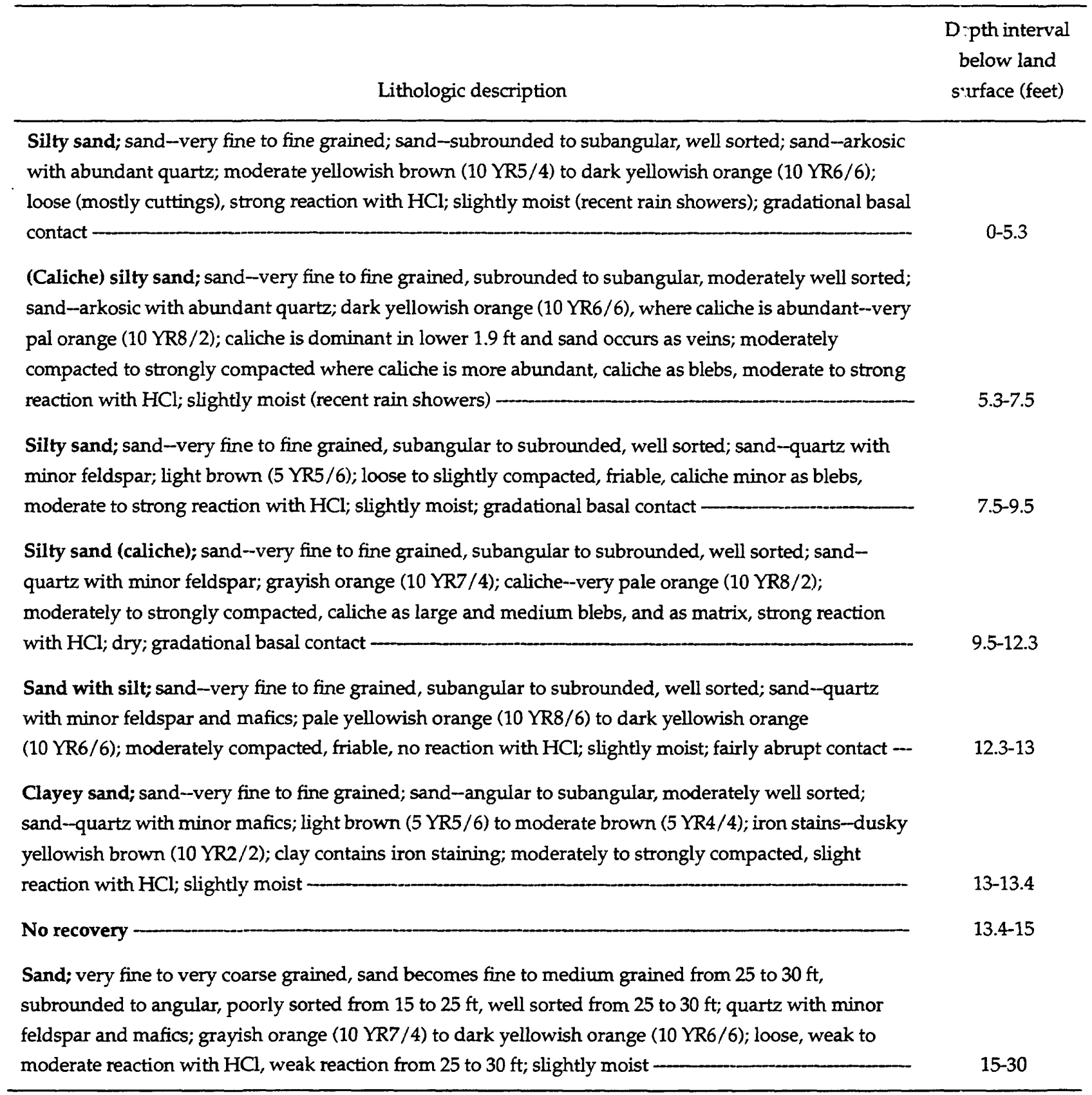




\section{Table 8.--Lithology penetrated by borehole GMP-8}

[Color codes are from the Rock-Color Chart (National Research Council, 1948). See figure 15 for protocol used in naming unconsolidated sediments. $\leq$, less than or equal to; $<$, less than;

$\%$, percent; ft, feet; mm, millimeters; $\mathrm{HCl}$, hydrochloric acid]

Silty sand; sand-very fine to fine grained, subangular to subrounded, moderately well sorted; sandarkosic with abundant quartz; moderate yellowish brown (10 YR5/4); loose, strong reaction with $\mathrm{HCl}$; dry; abrupt basal contact

Silty sand (caliche); sand-very fine to fine grained, pebbles $<1 \%$ and $\leq 10 \mathrm{~mm}$ toward bottom; sandsubangular, moderately well sorted; sand-arkosic with abundant quartz; grayish orange (10 YR7/4); caliche--very pale orange (10 YR8/2); strongly to moderately compacted, friable, strong reaction with $\mathrm{HCl}$; dry

Sand; very fine to very coarse grained, pebbles approximately $1 \%$ and $\leq 43 \mathrm{~mm}$; sand-subangular to subrounded, well graded, moderately well sorted coarse to very coarse grains in bottom $1.2 \mathrm{ft}$; sandquartz with minor feldspar and mafics; pebbles-quartzite, granite, andesite(?), magnetite(?), iron abundant; pale yellowish brown (10 YR6/2) to moderate yellowish brown (10 YR5/4); loose, strong reaction with $\mathrm{HCl}$; dry; abrupt basal contact

Silty sand (caliche); sand--very fine to fine grained, well sorted; sand--quartz with minor feldspar and mafics; grayish orange (10 YR7/4), very pale orange (10 YR8/2) where caliche is more abundant; 1- to 3$\mathrm{mm}$ lamination zones; moderately to very strongly compacted, loose in zones where less caliche, caliche as blebs, veins, and matrix, moderate to strong reaction with $\mathrm{HCl}$; dry where caliche is abundant, slightly moist where more sandy; abrupt basal contact

Sandy clay with caliche; sand-very fine grained; moderate brown (5 YR4/4) to moderate brown (5 YR3/4); caliche--very pale orange (10 YR8/2); iron stains/organic matter-dusky yellowish brown (10 YR2/2); organic matter abundant (roots); strongly compacted, caliche as blebs, veins, and matrix, friable, strong reaction with $\mathrm{HCl}$; dry to slightly moist

No core recovery; cuttings-Sand 
Table 9.--Lithology penetrated by borehole GMP-9

[Color codes are from the Rock-Color Chart (National Research Council, 1948). See figure 15 for protocol used in naming unconsolidated sediments. $\leq$, less than or equal to; $<$, less $\mathrm{t} \mathrm{r}^{\wedge} \mathrm{n}$; $\%$, percent; $\mathrm{ft}$, feet; $\mathrm{mm}$, millimeters; $\mathrm{HCl}$, hydrochloric acid; $\mathrm{CaCO}_{3}$, calcium carbonate]

Lithologic description

Desth interval

kelow land

strface (feet)

Silty sand; sand-very fine to fine grained; sand-subangular, well sorted; sand-arkosic; light brown (5 YR5/6); loose, moderate reaction with $\mathrm{HCl}$; slightly moist (from overnight rain showers); abrupt basal contact

Sandy silt (caliche); sand-very fine grained, minor medium grains, well sorted; sand-arkosic; very pale orange ( $10 \mathrm{YR} 8 / 2)$; loose, powdery, strong reaction with $\mathrm{HCl}$; dry; gradational basal contact -

Silty sand (caliche); sand-very fine to fine grained, pebbles $<1 \%$ and $\leq 12 \mathrm{~mm}$; sand-subangular; pebbles-subangular to subrounded; sand-quartz with minor feldspar and mafics; pebbles-quartzite, sandstone; grayish orange (10 YR7/4); caliche-very pale orange (10 YR8/2); moderately to strongly compacted, friable, caliche abundant as blebs, becoming less abundant toward bottom, strong reaction with $\mathrm{HCl}$; dry

Sand; fine to medium grained, pebbles $<1 \%$ and $\leq 25 \mathrm{~mm}$; sand-subangular; pebbles-subrounded to rounded, well graded; sand--arkosic with abundant quartz; pebbles-sandstone, quartzite; moderate yellowish brown (10 YR5/4); loose, no reaction with $\mathrm{HCl}$; slightly moist; abrupt basal contact

Sandy clay; sand-very fine to fine grained; sand--subangular; sand-arkosic; moderate brown (5 YR4 /4); caliche blebs-grayish orange (10 YR7/4); iron stains-dusky yellowish brown (10 YR2/2); moderately to strongly compacted, friable, caliche as blebs; clay-no to weak reaction with $\mathrm{HCl}$; calichestrong reaction with $\mathrm{HCl}$; slightly moist

No recovery

Sand; very fine to fine grained, angular to subangular, very well sorted; quartz with minor feldspar and mafics; moderate yellowish brown (10 YR5/4); iron stains-dusky yellowish brown (10 YR2/2); loose, no to weak reaction with $\mathrm{HCl}$; slightly moist to moist; gradational basal contact

Clayey sand; sand approximately $85 \%$ and very fine to medium grained, subangular, well graded; sand-quartz with minor feldspar and mafics; light brown (5 YR5/6); moderately compacted/cemented, $\mathrm{CaCO}_{3}$ cement, friable, $\mathrm{CaCO}_{3}$ as blebs and cement, moderate to strong reaction with $\mathrm{HCl}$, slightly moist; abrupt basal contact

Sand; very fine to very coarse grained, angular, subangular, and subrounded, well graded; quartz with minor feldspar and mafics; pale yellowish brown (10 YR6/2) to moderate yellowish brown (10 YR5/4); loose, moderate reaction with $\mathrm{HCl}$, strong reaction from 29 to $30.4 \mathrm{ft}$; slightly moist, slightly moist to moist from 29 to $30.4 \mathrm{ft}$ 
Table 10.--Lithology penetrated by borehole GMP-10

[Color codes are from the Rock-Color Chart (National Research Council, 1948). See figure 15 for protocol used in naming unconsolidated sediments. <, less than; \%, percent; $\mathrm{ft}$, feet; $\mathrm{mm}$, millimeters; $\mathrm{HCl}$, hydrochloric acid]

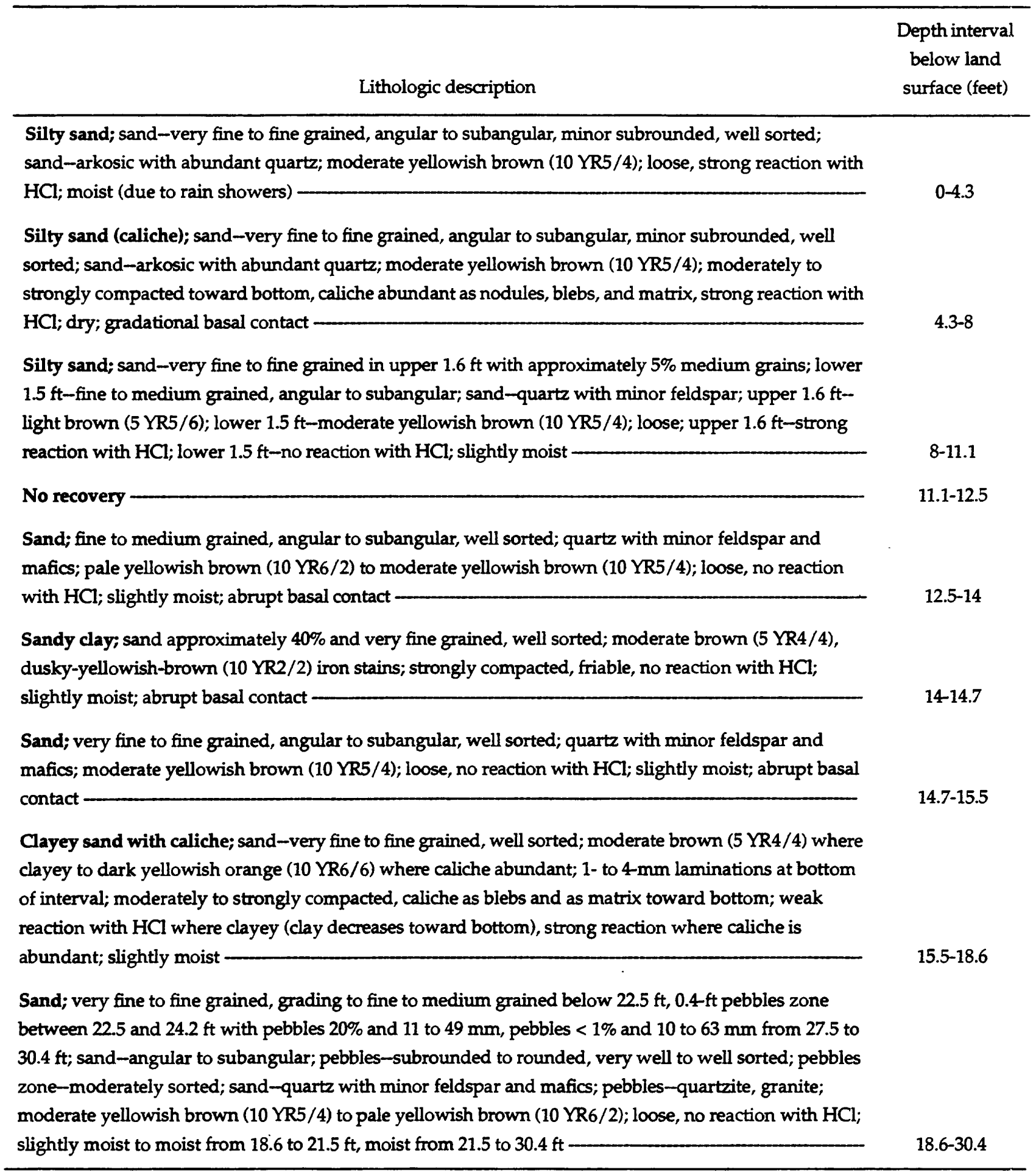




\section{Table 11.--Lithology penetrated by borehole BH-3}

[Color codes are from the Rock-Color Chart (National Research Council, 1948). See figure 15 for protocol used in naming unconsolidated sediments. $\leq$, less than or equal to; $<$, less than; $\%$, percent; ft, feet; $\mathrm{mm}$, millimeters; $\mathrm{HCl}$, hydrochloric acid; $\mathrm{CaCO}_{3}$, calcium carbonate; $\mathrm{SiO}_{2}$, silica]

Silty sand; sand--very fine to fine grained, approximately $5 \%$ medium grains in upper $3 \mathrm{ft}$; sand-subangular to subrounded, very well sorted; sand-quartz, minor mafics, and feldspar; moderate yellowish brown (10 YR5/4); loose to slightly compacted, caliche present in minor zones as matrix and blebs from 3 to $8 \mathrm{ft}$, moderately cemented in caliche zones, moderate reaction with $\mathrm{HCl}$, strong reaction in caliche zones; slightly moist

Silty sand and caliche; sand-very fine to fine grained, subangular to subrounded, very well sorted; sand-quartz, minor feldspar, and mafics; moderate yellowish brown (10 YR5/4), moderately to strongly cemented, $\mathrm{CaCO}_{3}$ cement, caliche abundant as matrix and blebs, strong reaction with $\mathrm{HCl}$; slightly moist; abrupt basal contact

Clay and caliche with sand; sand $\leq 15 \%$ and very fine to fine grained, very minor medium grains, well sorted; sand-quartz; clay-moderate brown (5 YR4/4) to moderate brown (5 YR3/4); caliche-pinkish gray (5 YR8/1); moderately to strongly compacted, caliche as matrix, blebs, and nodules, clay has weak reaction with $\mathrm{HCl}$, caliche, and some matrix has strong reaction; slightly moist-dried out quickly; organic material (roots) abundant; abrupt basal contact

Sand; very fine to fine grained, $<3 \%$ medium grains, pebbles $<1 \%$ and $\leq 38 \mathrm{~mm}, 0.4-\mathrm{ft}$ zone near $18.4 \mathrm{ft}$ has very fine to very coarse grains with $<10 \%$ pebbles, $\leq 38 \mathrm{~mm}$; sand-subangular to subrounded; pebbles-subrounded, well sorted, 0.4-ft zone is well graded; sand-quartz, very minor feldspar and mafics; pebbles-quartzite; pale yellowish brown (10 YR6/2); loose; no reaction with $\mathrm{HCl}$; slightly moist

Sand; very fine to very coarse grained, pebbles $<1 \%$ and $\leq 23 \mathrm{~mm}, 0.5$-ft zone with pebbles approximately $10 \%$ near $32.5 \mathrm{ft}$, one 70-mm cobble near top of section; sand-subangular to subrounded, well graded; sand-quartz, minor mafics; pebbles-quartzite, basalt(?); cobble-conglomerate; loose, no reaction with $\mathrm{HCl}$; moist

Sand; medium to very coarse grained, pebbles $<2 \%$ and $\leq 10 \mathrm{~mm}$, subangular to subrounded, well sorted; quartz, moderate feldspar, and mafics; pale yellowish brown (10 YR6/2); loose to slightly compacted; no reaction with $\mathrm{HCl}$; moist; abrupt basal contact

Sand; very fine to fine grained, subangular to subrounded, very well sorted; quartz, minor feldspar, and mafics; loose to slightly compacted, no reaction with $\mathrm{HCl}$; moist; gradational basal contact 
Sand with pebbles; sand-very fine to very coarse grained, pebbles $\leq 8 \%$ and $\leq 30 \mathrm{~mm}$, subangular to subrounded, well graded; sand-quartz, minor feldspar, and mafics; pebbles-quartzite, andesite(?); pale yellowish brown ( $10 \mathrm{YR} 6 / 2$ ); one approximately $55-\mathrm{mm}$ decomposing(?) pebble, $\mathrm{CaCO}_{3}$ cemented conglomerate, strong reaction with $\mathrm{HCl}$ at about $45 \mathrm{ft}$; loose to slightly compacted, zones of weakly cemented sand from 41 to $48 \mathrm{ft}, \mathrm{SiO}_{2}$ (?) cement, no reaction with $\mathrm{HCl}$; moist

Sand; fine grained, subangular to subrounded, very well sorted; quartz with minor feldspar and mafics; pale yellowish brown (10 YR6/2); loose; no reaction with $\mathrm{HCl}$; moist

Sand; very fine to very coarse grained, pebbles $<3 \%$ and $\leq 15 \mathrm{~mm}$, some clay present as blebs, sandsubangular to subrounded; pebbles-subrounded, well graded; sand-quartz with minor feldspar and mafics; pebbles-quartzite; sand-pale yellowish brown (10 YR6/2); clay-moderate yellowish brown (10 YR5/4); loose to slightly compacted, slight to moderate reaction with $\mathrm{HCl}$; moist

Sand; very fine to fine grained, some clay present as blebs; sand--subangular to subrounded, well sorted; sand-quartz with minor feldspar and mafics; sand-pale yellowish brown (10 YR6/2); claymoderate yellowish brown (10 YR5/4); loose to slightly compacted, no reaction with $\mathrm{HCl}$; moist 
Table 12.--Lithology penetrated by borehole MSWLF03

[Color codes are from the Rock-Color Chart (National Research Council, 1948). See figire 15 for protocol used in naming unconsolidated sediments. $\leq$, less than or equal to; $<$, less than; $\%$, percent; ft, feet; $\mathrm{mm}$, millimeters; $\mathrm{HCl}$, hydrochloric acid; $\mathrm{CaCO}_{3}$, calcium carbc nate]

\begin{tabular}{|c|c|}
\hline Lithologic description & $\begin{array}{l}\text { D roth interval } \\
\text { below land } \\
\text { surface (feet) }\end{array}$ \\
\hline For description of 0-56 ft see table 11. & $0-56$ \\
\hline $\begin{array}{l}\text { No recovery (few lumps of clay with abundant black organic matter left in barrel from } 49 \text { - to } 59 \text {-ft } \\
\text { drilling interval)- }\end{array}$ & \multirow[t]{2}{*}{$56-66$} \\
\hline $\begin{array}{l}\text { Clay; moderate yellowish brown ( } 10 \mathrm{YR} 5 / 4) \text {; very slick, shinny organic matter visible but not very } \\
\text { abundant; very strongly compacted, caliche present as nodules, no to weak reaction with } \mathrm{HCl} \text {, nodules }\end{array}$ & \\
\hline No recovery & $\begin{array}{l}66-67.2 \\
67.2-69\end{array}$ \\
\hline $\begin{array}{l}\text { Clay; moderate yellowish brown ( } 10 \text { YR5/4); pebbles below clay; moderately compacted, no to weak } \\
\text { reaction with } \mathrm{HCl} \text {; moist }\end{array}$ & $69-70$ \\
\hline $\begin{array}{l}\text { Sand and pebbles; only pebbles recovered, pebbles } \leq 40 \mathrm{~mm} \text {, subrounded to rounded; pebbles-- } \\
\text { quartzite, andesite, and granite }\end{array}$ & \multirow[t]{2}{*}{$70-72$} \\
\hline $\begin{array}{l}\text { Clayey silty sand; sand--very fine to fine grained, subangular, very well sorted; sand--quartz with } \\
\text { minor feldspar and mafics; clay--moderate brown ( } 5 \text { YR4/4); sand--moderate yellowish brown } \\
\text { (10 YR5/4); clay present as matrix, lenses, and blebs, grayish-black (N2) organic matter as veins and } \\
\text { blebs abundant in clay; moderately to strongly compacted, sand has weak to moderate reaction with }\end{array}$ & \\
\hline $\mathrm{HCl}$, clay has no reaction; moist & \multirow{2}{*}{$\begin{array}{c}72-79.4 \\
79.4-91.4\end{array}$} \\
\hline No recovery & \\
\hline $\begin{array}{l}\text { Silty sand with clay; sand-very fine grained, very well sorted; sand-quartz; pale yellowish brown } \\
\text { (10 YR6/2) to moderate yellowish brown ( } 10 \text { YR5/4) where clayey; clay minor and in zones as lenses } \\
\text { with grayish-black (N2) organic matter as blebs between laminated clay lenses; loosely compacted, } \\
\text { moderately compacted in the presence of clay, caliche present as matrix and minor as veins broken in the }\end{array}$ & \multirow{3}{*}{$91.4-92$} \\
\hline presence of clay, moderate to strong reaction with $\mathrm{HCl}$; moist & \\
\hline $\begin{array}{l}\text { Sand; upper approximately } 4 \mathrm{ft} \text {-very fine to fine grained with silt; lower approximately } 1.4 \mathrm{ft} \text {-fine to } \\
\text { medium grained with approximately } 3 \% \text { medium to very coarse grains and }<0.5 \% \text { pebbles } \leq 35 \mathrm{~mm} \text {; } \\
\text { sand-subangular to subrounded; pebbles-subrounded to rounded; upper approximately } 4 \mathrm{ft} \text {-very well } \\
\text { sorted; lower approximately } 1.4 \mathrm{ft} \text {-moderately well sorted to moderately well graded; sand--quartz, } \\
\text { feldspar, and minor mafics; upper approximately } 4 \mathrm{ft} \text {-moderate yellowish brown ( } 10 \mathrm{YR} 5 / 4) \text {; lower } \\
\text { approximately } 1 \mathrm{ft} \text {-pale yellowish brown ( } 10 \mathrm{YR} 6 / 2) \text {; upper } 4 \mathrm{ft} \text {-moderately compacted, no reaction } \\
\text { with } \mathrm{HCl} \text {; lower } 1.4 \mathrm{ft} \text {-slightly compacted / weakly cemented(?), moderately cemented when dried out, } \\
\mathrm{CaCO}_{3} \text { cement, weak to moderate reaction with } \mathrm{HCl} \text { when wet, strong reaction when dried out; upper } 4\end{array}$ & \\
\hline $\mathrm{ft}$-moist; lower $1 \mathrm{ft}$-very moist to wet & $92-97.4$ \\
\hline No recovery & 97.4-102 \\
\hline
\end{tabular}


Table 12.--Lithology penetrated by borehole MSWLF03--Continued

Depth interral

below land

Lithologic description

surface (feet)

Silty sand with clay; sand-very fine to fine grained; sand--subangular, well sorted sand; sand-quartz with minor feldspar and mafics; sand-moderate yellowish brown (10 YR5/4); clay-moderate brown (5 YR4/4); clay present mostly as lenses blebs, pebbles at bottom of recovery $\leq 35 \mathrm{~mm}$, subrounded to rounded, quartzite, andesite, dacite(?); moderately compacted, moderate reaction with $\mathrm{HCl}$, grayish black (N2) organic matter present in some clay zones; moist

$102-102.4$

No recovery (driller reported 102- to 108-ft interval as approximately $4 \mathrm{ft}$ sand, then approximately $1.5 \mathrm{ft}$ clay(?) and $0.5 \mathrm{ft}(?)$ sand)

102.4-108

Silty sand; sand-very fine to fine grained; sand--subangular, very well sorted; sand-quartz, minor mafics toward bottom; moderate yellowish brown (10 YR5/4); minor clay stringers-moderate brown (5 YR4/4), pale yellowish brown (10 YR6/2) and moderate yellowish brown (10 YR5/4) toward bottom; slightly compacted, friable in lower $0.4 \mathrm{ft}$, no reaction with $\mathrm{HCl}$, 3-inch $\mathrm{CaCO}_{3}$ cemented sand lens at 118 $\mathrm{ft}$ is very strongly cemented and has strong reaction with $\mathrm{HCl}$; moist

Sandstone; $\mathrm{CaCO}_{3}$ cemented sand lens; very strongly cemented, strong reaction with $\mathrm{HCl}$

No recovery (driller reported soft drilling from 123 to $133 \mathrm{ft}$, probably sand, pebbles at top of 133- to 136.6-ft interval $\leq 38 \mathrm{~mm}$; subrounded to rounded; andesite, cross-bedded fine-grained sandstone) -.-.-.

Silty sand; sand-very fine grained, well sorted; sand-quartz; moderate yellowish brown (10 YR5/4) with pale-brown (5 YR5/2) clay zones at top to dark yellowish orange (10 YR6/6) at middle to moderate yellowish brown (10 YR5/4) toward bottom; moderately to strongly compacted, stronger where clay is present, caliche as matrix, nodules, and blebs in clay zones have strong reaction with $\mathrm{HCl}$, otherwise no reaction with $\mathrm{HCl}$; moist

No recovery

Silty clay; moderate yellowish brown (10 YR5/4); organic matter-grayish black (N2); caliche-very pale orange (10 YR8/2); clay laminated around caliche nodules; very strongly compacted caliche present as nodules $\leq 30 \mathrm{~mm}$, clay has no reaction with $\mathrm{HCl}$, nodules have strong reaction; moist; gradational basal contact

Sand with silt; sand-very fine to fine grained, very well sorted; sand-quartz with minor mafics, moderate yellowish brown (10 YR5/4); slightly compacted, moderate reaction with $\mathrm{HCl}$; moist; gradational basal contact

Clayey sand; sand-very fine grained, well sorted; moderate yellowish brown (10 YR5/4); moderately to strongly compacted, weak reaction with $\mathrm{HCl}$; moist; gradational basal contact

Clay; moderate yellowish brown (10 YR5/4); organic veins-grayish black (N2); 1- to 2-mm laminations, shiny clay; strongly compacted, caliche present as stringers; clay-weak reaction with $\mathrm{HCl}$; calichestrong reaction; moist; gradational basal contact 
Clayey silty sand; sand--very fine grained, very well sorted; sand-quartz with minor feldspar and mafics; dark yellowish orange (10 YR6/6) to moderate yellowish brown (10 YR5/4); strongly compacted, no reaction with $\mathrm{HCl}$; moist; gradational basal contact

Sandy silty clay; sand-very fine grained; moderate brown (5 YR4/4); strongly compacted/cemented, caliche as matrix and nodules $\leq 30 \mathrm{~mm}$, weak to strong reaction with $\mathrm{HCl}$ (nodules have strong reaction); moist; gradational basal contact -

Silty sand; sand-very fine to fine grained, well sorted; sand-quartz with minor mafics; dark yellowish orange (10 YR6/6) to moderate yellowish brown (10 YR5/4); moderately compacted/cemented, $\mathrm{CaCO}_{3}$ cement, friable when dry; moist

No recovery (driller reported sand and gravel for interval)

Clayey silty sand; sand-very fine grained, well sorted; dark yellowish orange (10 YR6/6) to moderate yellowish brown (10 YR5/4); strongly compacted caliche present as matrix and as nodules, moderate to strong reaction with $\mathrm{HCl}$; moist; gradational basal contact

Silty clay; moderate brown (5 YR4/4) with grayish-black (N2) organic blebs and stringers; some laminations, shiny in zones; moderately to strongly compacted, no to weak reaction with $\mathrm{HCl}$, moist; abrupt basal contact

Sandstone (lens); sand-medium grained, subangular, well sorted; quartz with minor mafics and feldspar; pale yellowish brown ( $10 \mathrm{YR} 6 / 2$ ); very strongly cemented, $\mathrm{CaCO}_{3}$ cement, strong reaction with $\mathrm{HCl}$; moist

Clayey silty sand; sand-very fine grained, well sorted; moderate yellowish brown (10 YR5/4); moderately compacted/cemented, $\mathrm{CaCO}_{3}$ cement, somewhat friable when dry, moderate reaction with $\mathrm{HCl}$; moist; gradational basal contact

Clay; very fine grained sand stringers; moderate brown (5 YR4/4) with grayish-black (N2) organic blebs and stringers; clay is shiny in zones and somewhat laminated; strongly compacted, caliche present as nodules $\leq 10 \mathrm{~mm}$, clay has no reaction with $\mathrm{HCl}$, caliche has strong reaction; moist; abrupt basal contact Silty sand; sand-very fine grained, very well sorted; sand-quartz with minor feldspar; moderate yellowish brown (10 YR5/4) with zones of light-brown (5 YR5/6) stains(?); no reaction with $\mathrm{HCl}$, slightly compacted; moist, gradational basal contact

Silty clay; moderate yellowish brown (10 YR5/4) with stringers of light-brown (5 YR5/6) stains; moderately compacted, $\mathrm{CaCO}_{3}$ present as matrix, moderate reaction with $\mathrm{HCl}, 1-\mathrm{mm}$ white (N9) veins have no reaction with $\mathrm{HCl}$; moist abrupt basal contact

Silty sand; sand--very fine grained, very well sorted; sand-quartz; moderate yellowish brown (10 YR5/4) to dark yellowish orange (10 YR6/6); slightly compacted/cemented, soft and somewhat friable, $\mathrm{CaCO}_{3}$ cement, weak to moderate reaction with $\mathrm{HCl}$; moist; gradational basal contact 
(minated; strongly compacted, caliche contact

Silty sand; sand-very fine grained, very well sorted; moderate yellowish brown (10 YR5/4); moderately compacted, moderate reaction with $\mathrm{HCl}$; moist; abrupt basal contact

Silty clay; moderate yellowish brown (10 YR5/4); zones of lamination; moderately compacted, no to weak reaction with $\mathrm{HCl}$; moist

Silty clay; moderate yellowish brown (10 YR5/4); zones of lamination, grayish-black (N2) organic matter as blebs and veins; moderately compacted, no to weak reaction with $\mathrm{HCl}$; moist; gradational basal contact

Silty sand; very fine grained, well sorted; moderate yellowish brown (10 YR5/4); moderately compacted/cemented, moderate to strong reaction with $\mathrm{HCl}$, friable when dry, moist; gradational basal contact

Silty clay; moderate yellowish brown (10 YR5/4) to moderate brown (5 YR4/4); moderately to strongly compacted, no reaction with $\mathrm{HCl}$; moist 
Clay nodule; moderate brown (5 YR4/4); organic material-grayish black (N2); organic matter as blebs, clay shiny; moderately compacted, friable when dry, no reaction with $\mathrm{HCl}$; moist; abrupt basal contact

Sand; fine to medium grained, subangular to subrounded, moderately sorted/graded; pale reddish brown (10 YR6/2) to moderate yellowish brown (10 YR5/4); loose, no reaction with $\mathrm{HCl}$; very wet/wet; abrupt basal contact

Clay; lens, laminated, organic matter abundant; moderate yellowish brown (10 YR5/4); organic matter--grayish black (N2); strongly compacted, caliche as matrix, moderate reaction with $\mathrm{HCl}$, moist; abrupt basal contact

Sand; medium grained, $<2 \%$ very coarse grains, subangular to subrounded, well sorted; quartz with minor feldspar and mafics; loose, no to weak reaction with $\mathrm{HCl}$; very wet to wet

Sand; medium grained, $<2 \%$ very coarse grains, subangular to subrounded, well sorted; quartz with minor feldspar and mafics; loose, some $\mathrm{CaCO}_{3}$ cementing at bottom, no to weak reaction with $\mathrm{HCl}$, bottom has strong reaction with $\mathrm{HCl}$; very wet to wet

Silty clay; moderate brown (5 YR4/4); moderately compacted, friable when dry, moderate reaction with $\mathrm{HCl}$; moist; abrupt basal contact

Silty sand; sand-fine grained, very well sorted; sand--quartz with minor feldspar and mafics; light brown (5 YR5/6) to moderate yellowish brown (10 YR5/4); weakly compacted, no reaction with $\mathrm{HCl}$; moist

Silty sand with clay; sand-very fine grained, sand is well sorted; sand-quartz with minor feldspar and mafics; moderate brown (5 YR4/4) to light brown (5 YR5/6); moderately compacted, no reaction with 


\begin{tabular}{|c|}
\hline Lithologic description \\
\hline $\begin{array}{l}\text { Sand; fine grained, subangular to subrounded, very well sorted; quartz with minor feldspar and mafics; } \\
\text { pale yellowish brown (10 YR6/2) to moderate yellowish brown (10 YR5/4); loose, no reaction with } \mathrm{HCl} \text {; }\end{array}$ \\
\hline
\end{tabular}

\section{No recovery}

Silty sandy clay; sand-very fine grained, sand is well sorted; moderate yellowish brown (10 YR5/4) to moderate brown (5 YR4/4); caliche present as matrix and nodules $\leq 30 \mathrm{~mm}$, strongly compacted, some cementing, moderate to strong reaction with $\mathrm{HCl}$; moist; abrupt basal contact

Sand; fine grained, subangular to subrounded, very well sorted; quartz with minor feldspar and mafics; pale yellowish brown (10 YR6/2) to moderate yellowish brown (10 YR5/4); iron stringers $\leq 10 \mathrm{~mm}$ thick at top and bottom of section (strong magnetic reaction); weakly compacted, no reaction with $\mathrm{HCl}$; very moist; abrupt basal contact

Silty sandy clay; sand--very fine grained; sand--well sorted; moderate brown (5 YR4/4) to moderate yellowish brown (10 YR5/4); moderately to strongly compacted moist

Clay; moderate brown (5 YR4/4); very tight, shiny and compacted, very minor zones of caliche nodules $\leq 10 \mathrm{~mm}$ and minor organics as blebs, clay has no reaction with $\mathrm{HCl}$; moist

Sand with silt; sand-fine to very fine grained, subangular, well sorted; sand-quartz with minor feldspar and mafics; moderate brown (5 YR4/4); loose, no reaction with $\mathrm{HCl}$; moist

Sand; fine to very fine grained, pebbles $<3 \%$ and $<35 \mathrm{~mm}$; pebbles--subrounded, sand coarser toward bottom of interval, subangular, well sorted; sand-quartz with minor feldspar and mafics; pebblesquartzite, granite; moderate brown (5 YR4/4); silty clay laminations 3 to $15 \mathrm{~mm}$ thick scattered throughout section; loose, no reaction with $\mathrm{HCl}$, moist

Clayey sand; very fine grained, angular, well sorted; quartz with minor feldspar and mafics; light brown (5 YR5/6); compacted, no reaction with $\mathrm{HCl}$; moist; abrupt basal contact

Silty clay; moderate brown (5 YR4/4); compacted, moderate reaction with $\mathrm{HCl}$; dry; abrupt basal contact

Silty sand; subangular to subrounded, well sorted; quartz with minor feldspar and mafics; moderate yellowish brown (10 YR5/4); loose, no reaction with $\mathrm{HCl}$; wet; abrupt basal contact

Clay with silt; moderate brown (5 YR4/4); strongly compacted, weak reaction with $\mathrm{HCl}$; moist; gradational basal contact 


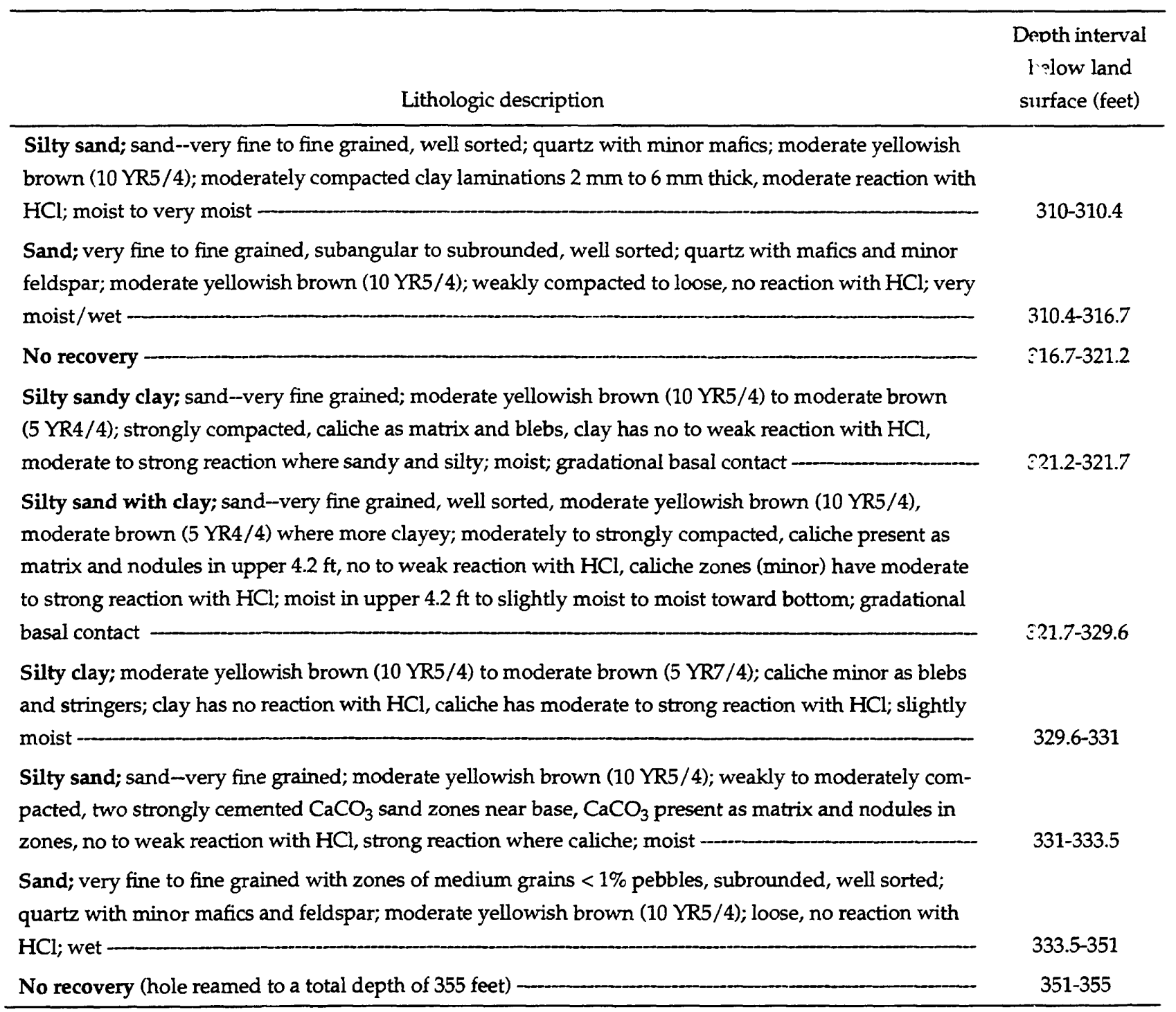




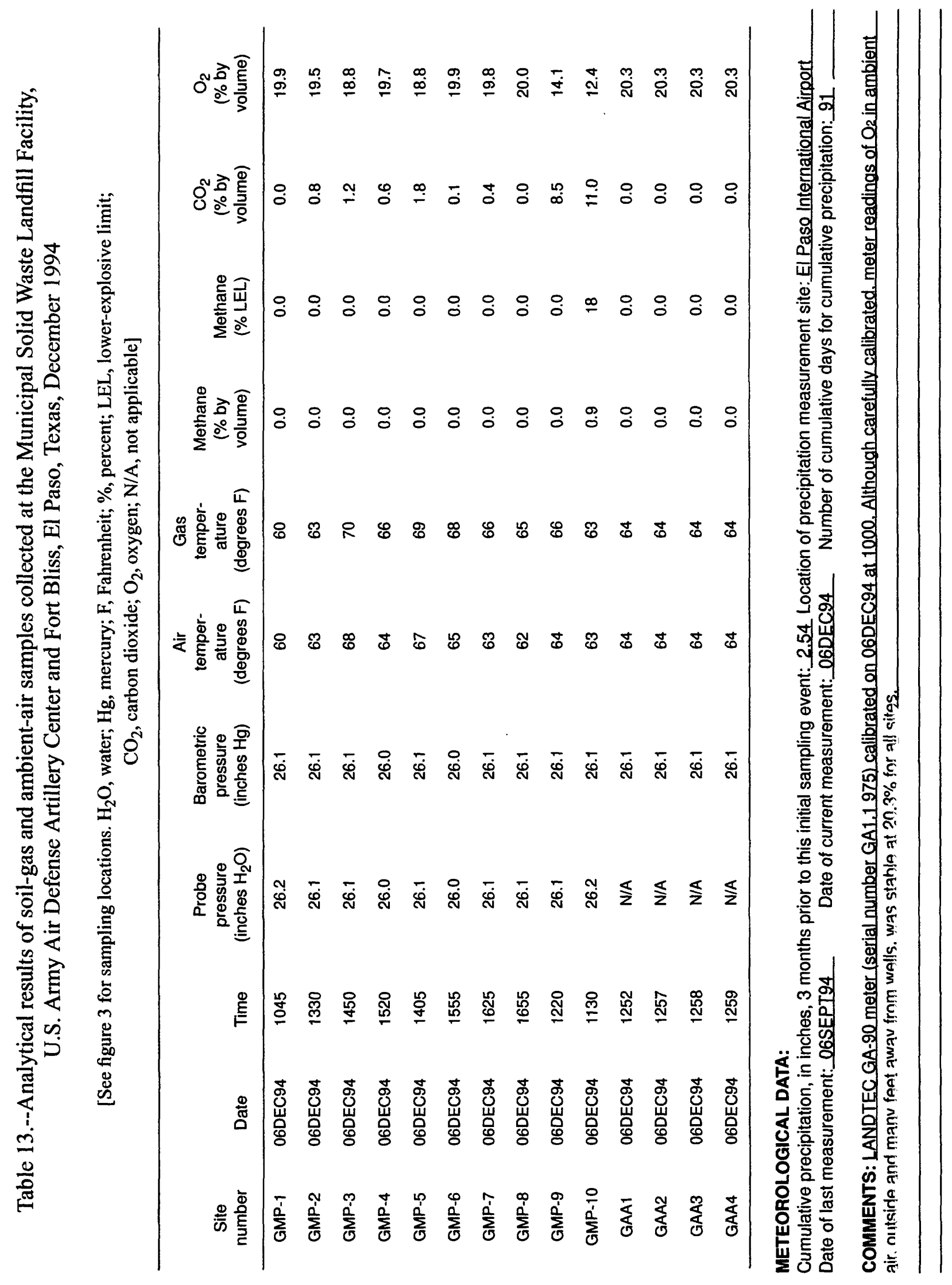




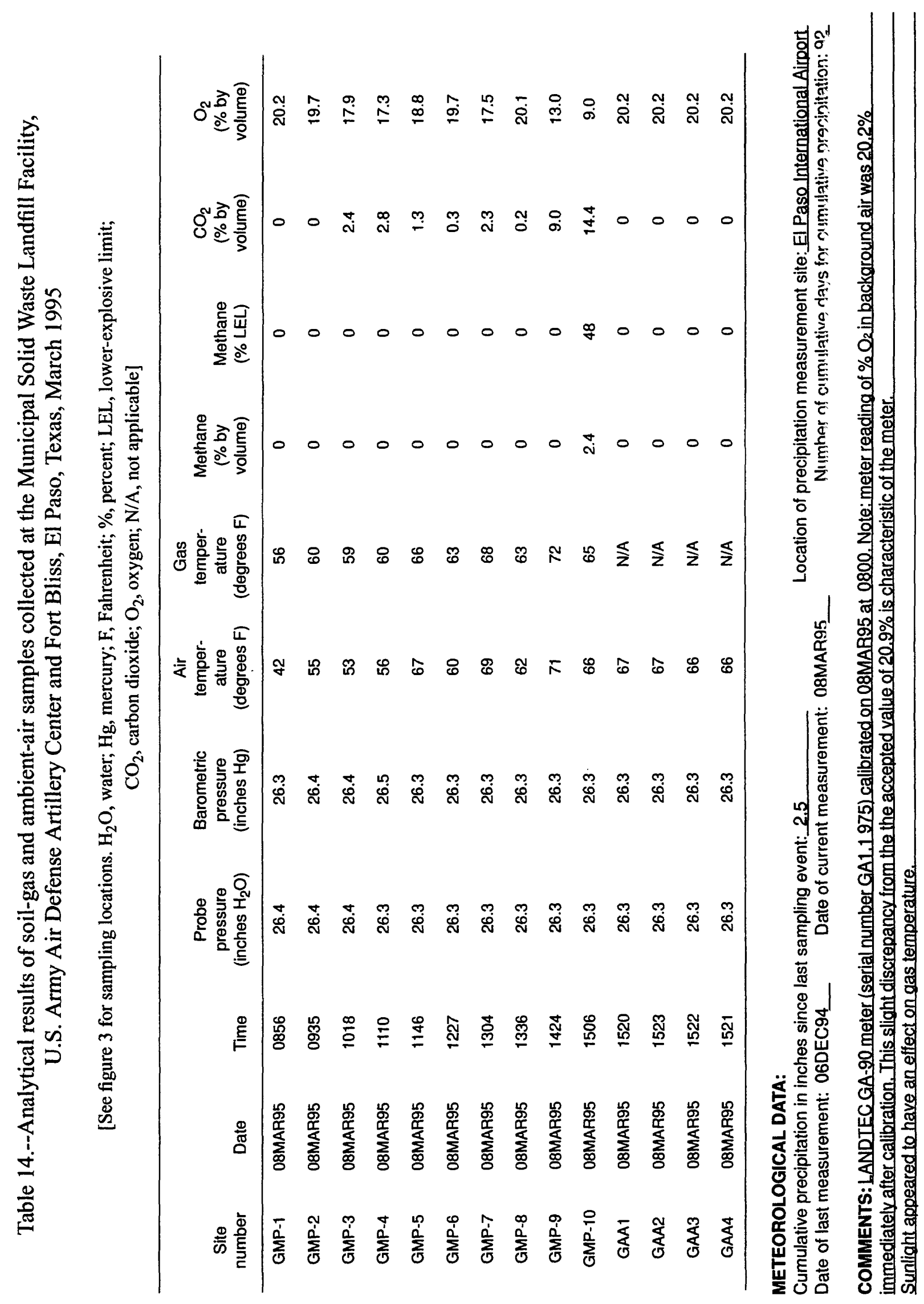


或

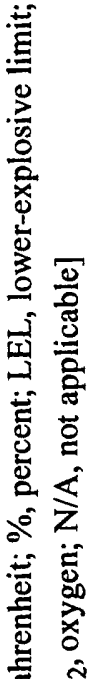

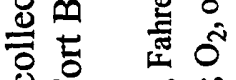

造安

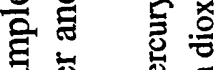

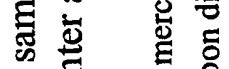

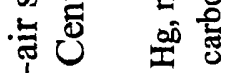

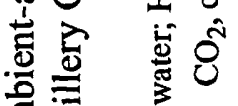

巻

定

สู

ดิ

家麦

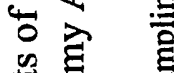

焉玄

ชู่

密

造

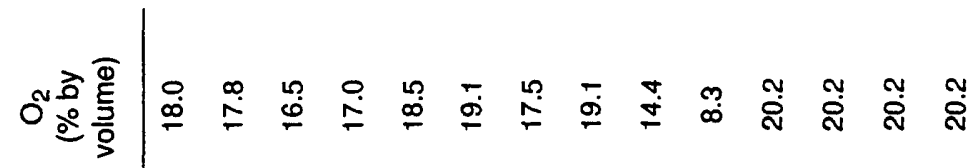

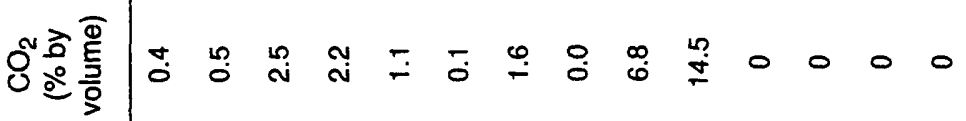

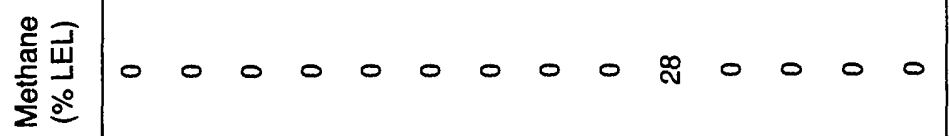

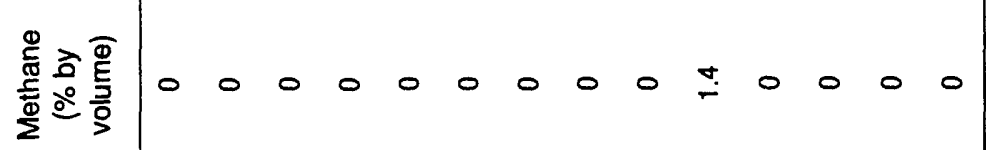

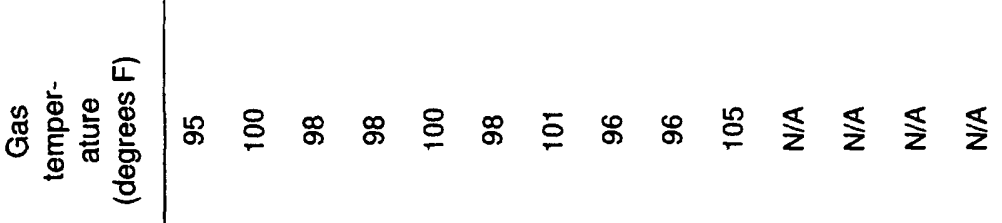

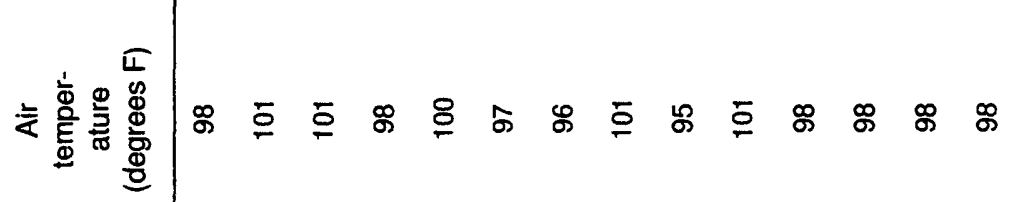

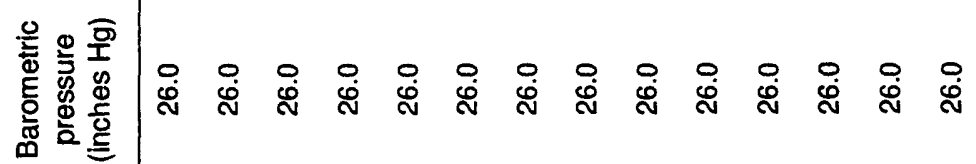

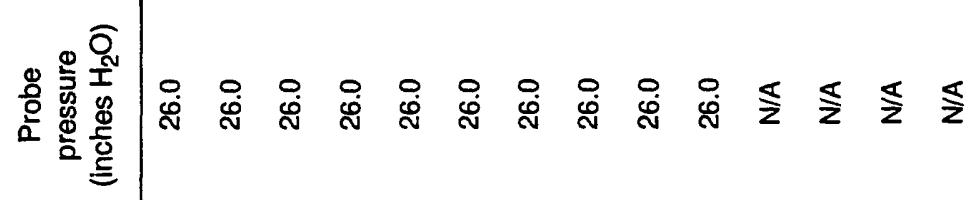

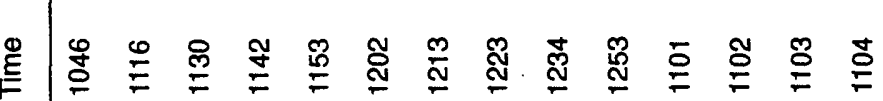

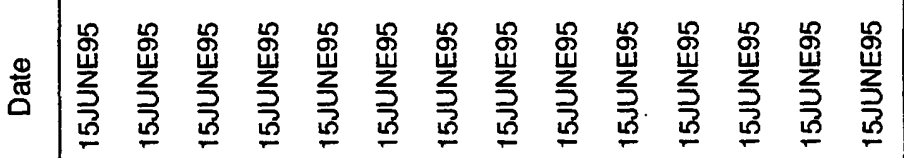

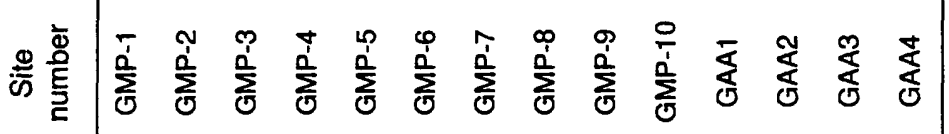

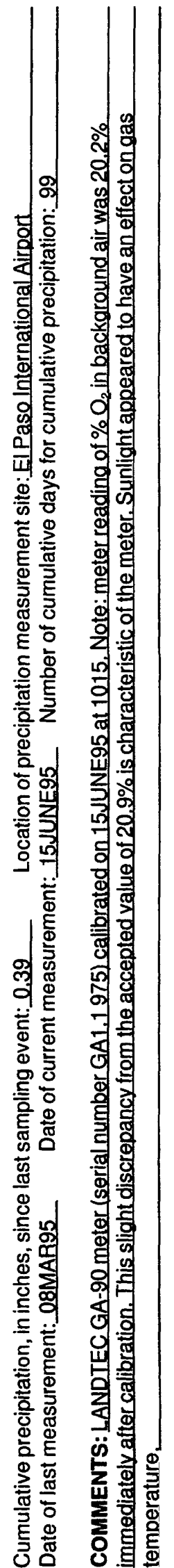




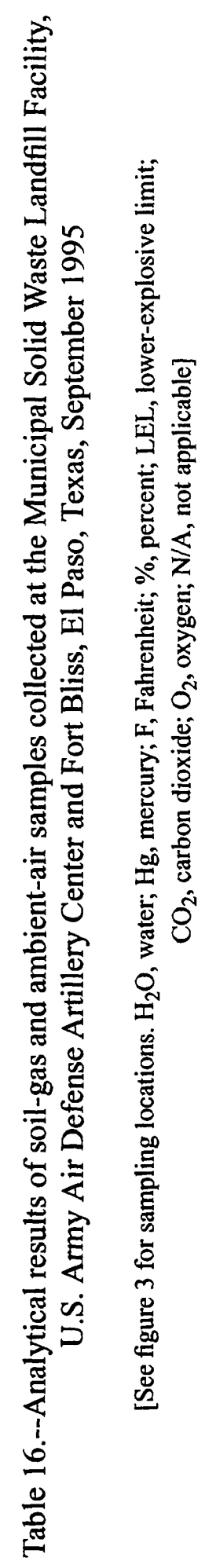

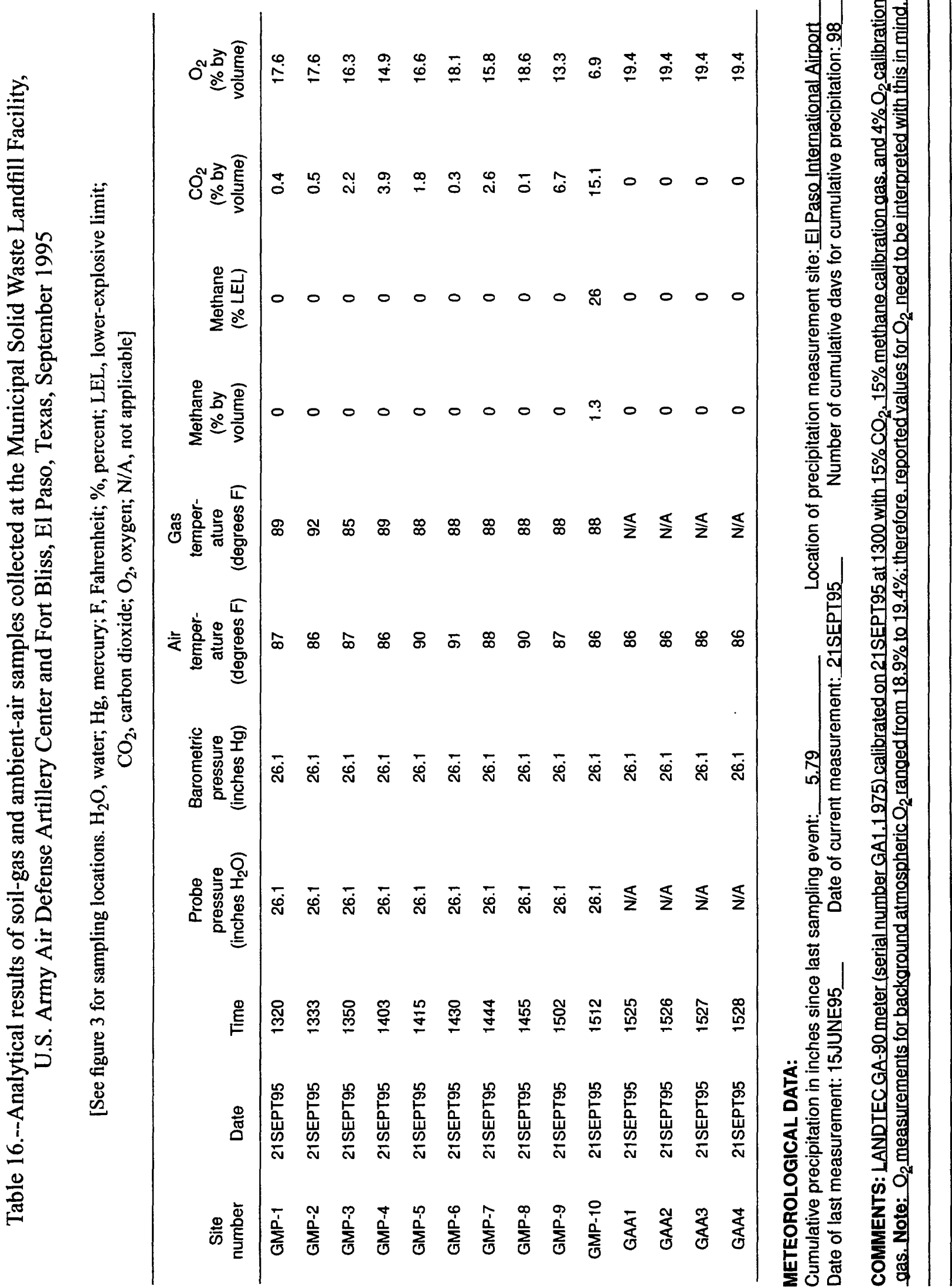

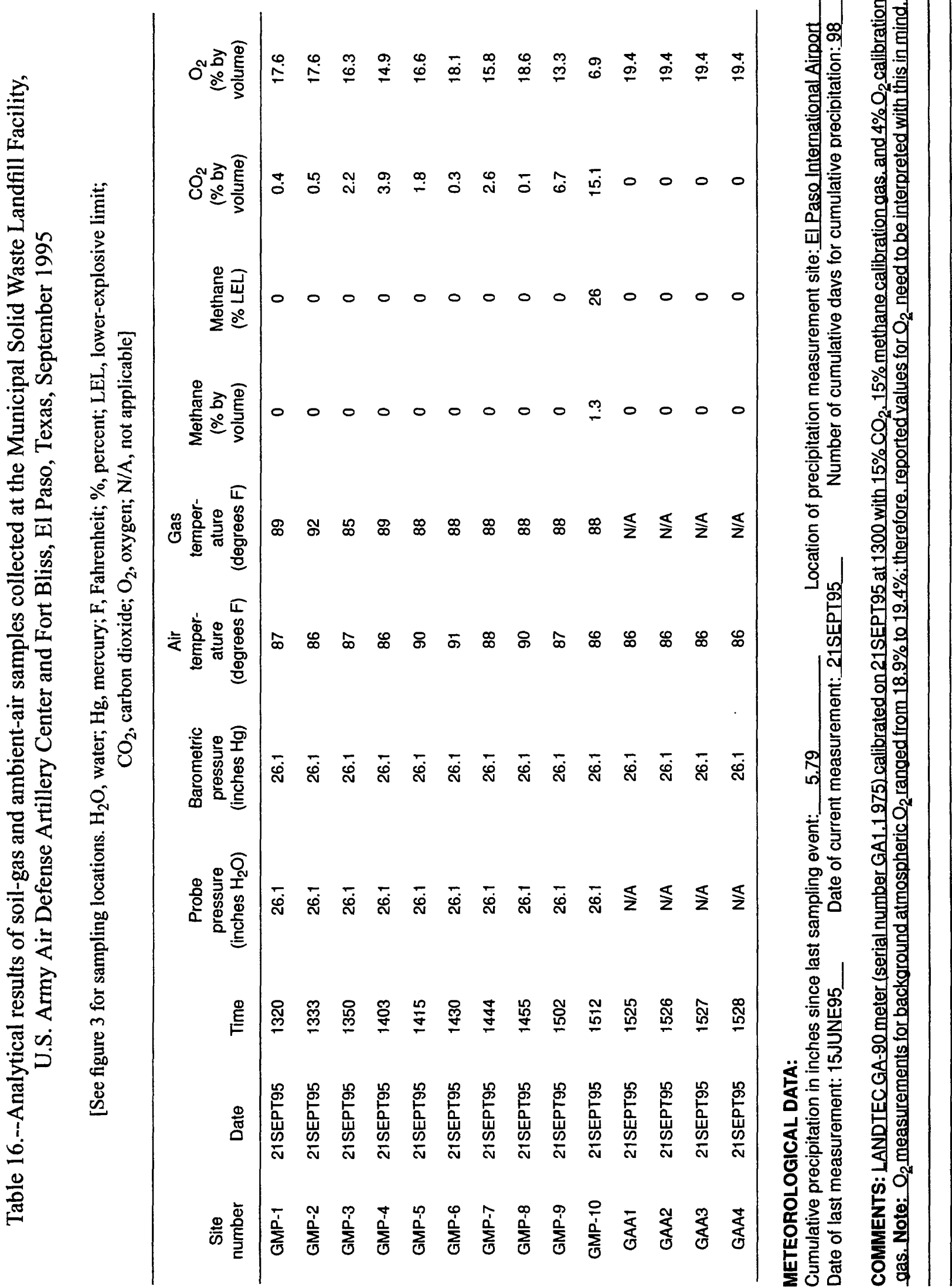

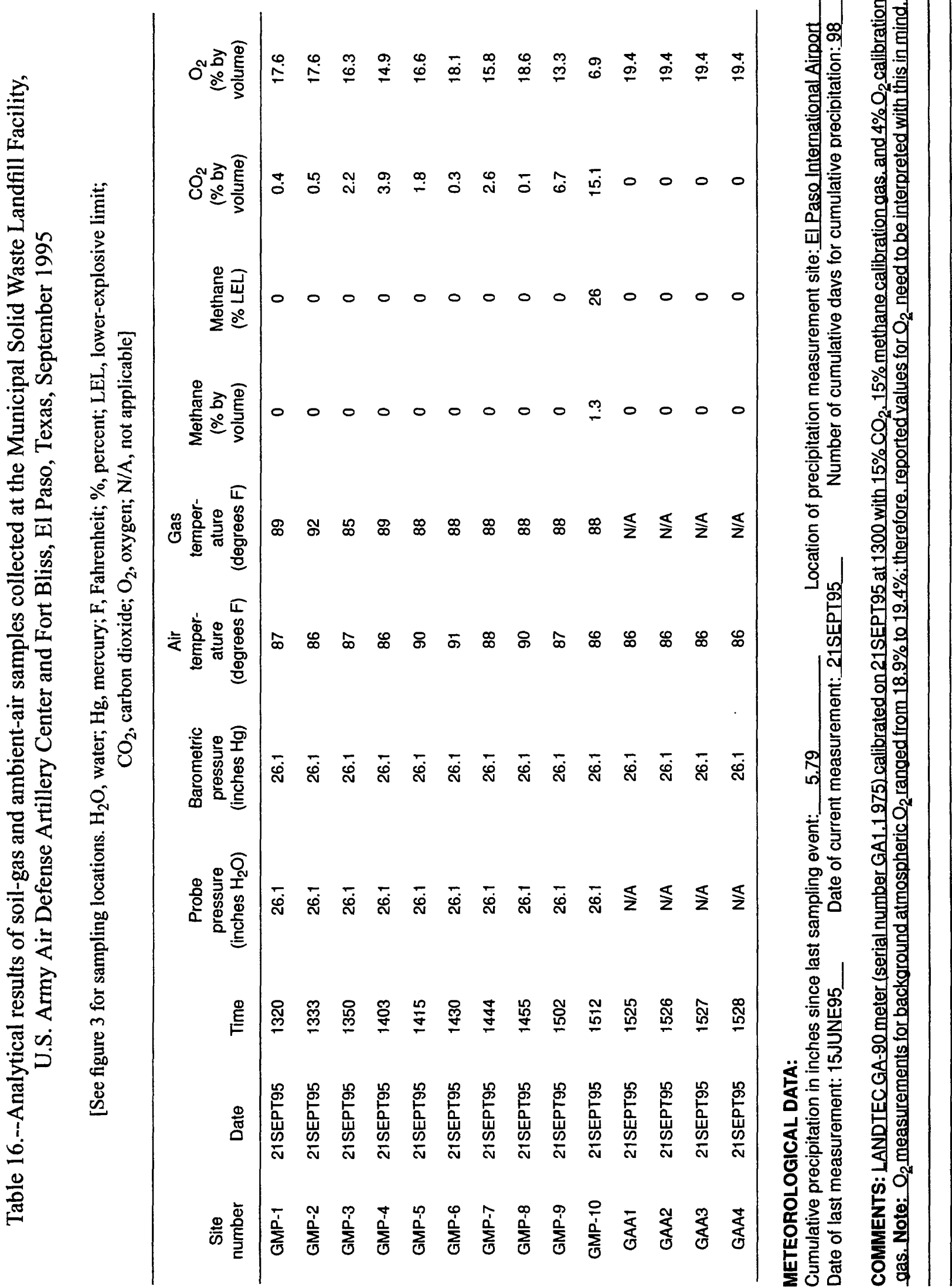

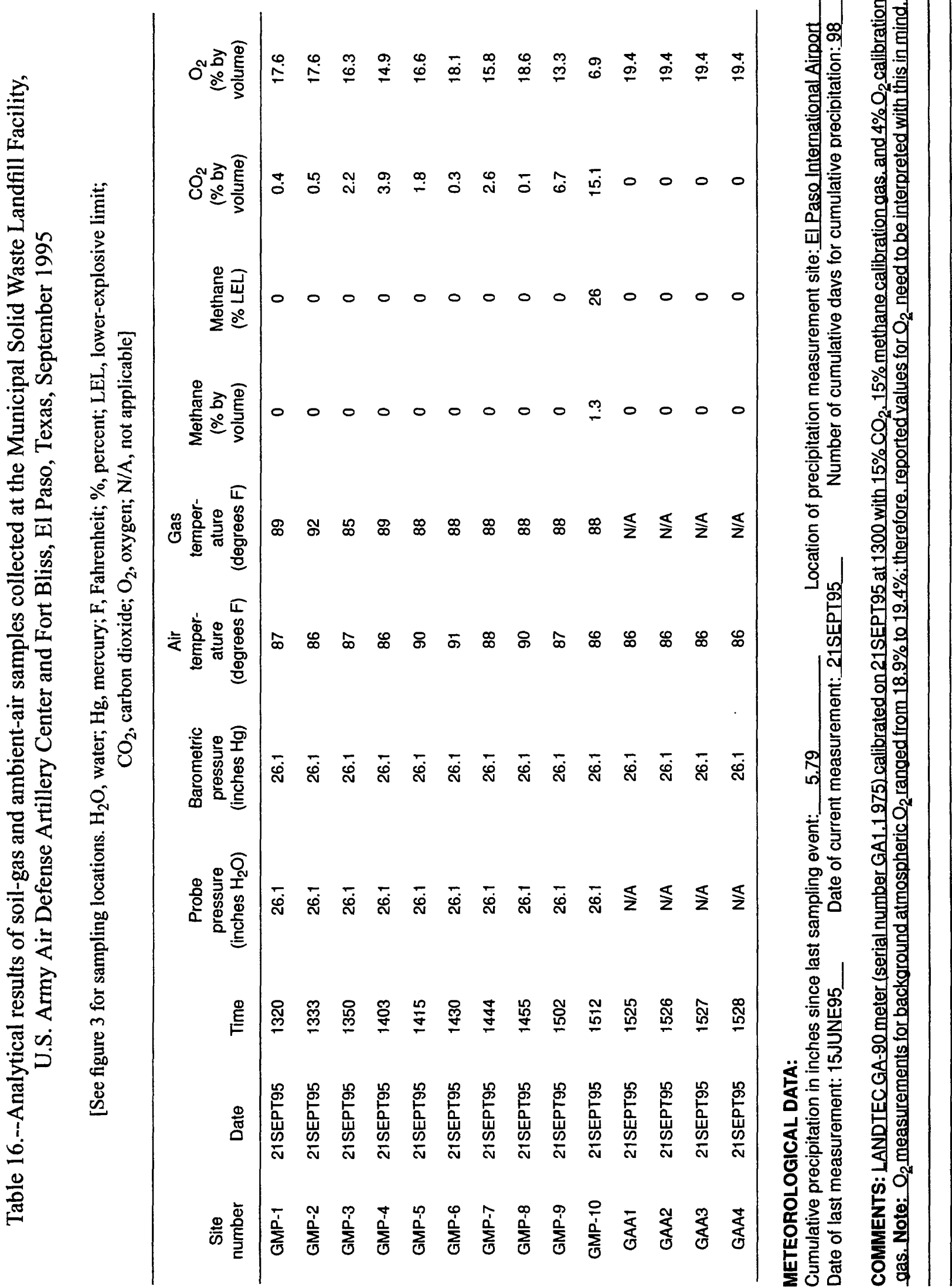
1 
Table 17.--Soil-chemical results ${ }^{1}$ of soil samples collected from borehole BH-3, Municipal Solid Waste Landfill Facility, U.S. Army Air Defense Artillery Center and Fort Bliss, El

\section{Paso, Texas}

[Qualifier codes are identified in table 18. --, no data; ASL, above sea level; $\mathrm{mg} / \mathrm{kg}$, milligrams per kilogram; ND, not detected]

\begin{tabular}{|c|c|c|c|c|c|}
\hline Parameter and units & $\begin{array}{l}\text { Method } \\
\text { number } 2\end{array}$ & $\begin{array}{l}\text { Reporting } \\
\text { limit }\end{array}$ & $\begin{array}{c}\text { Soil sample from } \\
5 \text { feet below land } \\
\text { surface } \\
\text { result/ qualifier }\end{array}$ & $\begin{array}{l}\text { Soil sample from } \\
20 \text { feet below } \\
\text { land surface } \\
\text { result/qualifier }\end{array}$ & $\begin{array}{l}\text { Soil sample frcm } \\
50 \text { feet below } \\
\text { land surface } \\
\text { result/qualifi is }\end{array}$ \\
\hline Date & - & - & 25APR95 & 25APR95 & 26APR95 \\
\hline Time & - & - & 1330 & 1655 & 0958 \\
\hline USGS sample number & - & - & MSWLF0302 & MSWLF0303 & MSWLF030ب \\
\hline Laboratory sample number & - & - & $041760-0002-S A$ & $041760-0003-S A$ & $041760-0004-S A$ \\
\hline Sample depth, elevation, feet ASL & - & 0.1 & $3,911.1$ & $3,896.1$ & $3,866.1$ \\
\hline \multicolumn{6}{|l|}{ Volatile organic compounds: } \\
\hline Acetone, mg/kg & SW8240 & 0.10 & ND & ND & ND \\
\hline Acrolein, mg/kg & SW8240 & 0.30 & ND & ND & ND \\
\hline Acrylonitrile, $\mathrm{mg} / \mathrm{kg}$ & SW8240 & 0.20 & ND & ND & ND \\
\hline Benzene, mg/kg & SW8240 & 0.10 & ND & ND & ND \\
\hline Bromodichloromethane, $\mathrm{mg} / \mathrm{kg}$ & SW8240 & 0.10 & ND & ND & ND \\
\hline Bromoform, mg/kg & SW8240 & 0.10 & ND & ND & $\mathrm{ND}$ \\
\hline Bromomethane, $\mathrm{mg} / \mathrm{kg}$ & SW8240 & 0.10 & ND & ND & ND \\
\hline Carbon disulfide, $\mathrm{mg} / \mathrm{kg}$ & SW8240 & 0.10 & ND & ND & ND \\
\hline Carbon tetrachloride, $\mathrm{mg} / \mathrm{kg}$ & SW8240 & 0.10 & ND & ND & ND \\
\hline Chlorobenzene, $\mathrm{mg} / \mathrm{kg}$ & SW8240 & 0.10 & $\mathrm{ND}$ & ND & $\mathrm{ND}$ \\
\hline Chioroethane, mg/kg & SW8240 & 0.10 & ND & ND & ND \\
\hline Chloroform, mg/kg & SW8240 & 0.10 & ND & ND & ND \\
\hline Chloromethane, $\mathrm{mg} / \mathrm{kg}$ & SW8240 & 0.10 & ND & ND & ND \\
\hline Dibromochloromethane, $\mathrm{mg} / \mathrm{kg}$ & SW8240 & 0.10 & ND & ND & ND \\
\hline Dibromomethane, mg/kg & SW8240 & 0.10 & ND & ND & ND \\
\hline Dichlorodifluoromethane, $\mathrm{mg} / \mathrm{kg}$ & SW8240 & 0.10 & ND & ND & ND \\
\hline Ethanol, $\mathrm{mg} / \mathrm{kg}$ & SW8240 & - & $\mathrm{ND} / \mathrm{c}$ & $\mathrm{ND} / \mathrm{c}$ & $\mathrm{ND} / \mathrm{c}$ \\
\hline Ethylbenzene, mg/kg & SW8240 & 0.10 & ND & ND & ND \\
\hline Ethyl methacrylate, $\mathrm{mg} / \mathrm{kg}$ & SW8240 & 0.10 & ND & ND & ND \\
\hline Iodomethane, mg/kg & SW8240 & 0.10 & ND & ND & ND \\
\hline Methylene chloride, $\mathrm{mg} / \mathrm{kg}$ & SW8240 & 0.10 & $0.0077 / j$ & $0.0072 / \mathrm{j}$ & $0.0078 / \mathrm{j}$ \\
\hline Styrene, mg/kg & SW8240 & 0.10 & ND & ND & ND \\
\hline Tetrachloroethene, $\mathrm{mg} / \mathrm{kg}$ & SW8240 & 0.10 & ND & ND & ND \\
\hline \multicolumn{6}{|l|}{ Volatile organic compounds--Continued: } \\
\hline Toluene, mg/kg & SW8240 & 0.10 & ND & ND & ND \\
\hline Trichloroethene, $\mathrm{mg} / \mathrm{kg}$ & SW8240 & 0.10 & ND & ND & ND \\
\hline Trichlorofluoromethane, $\mathrm{mg} / \mathrm{kg}$ & SW8240 & 0.10 & ND & ND & ND \\
\hline Vinyl acetate, $\mathrm{mg} / \mathrm{kg}$ & SW8240 & 0.30 & ND & ND & ND \\
\hline Vinyl chloride, $\mathrm{mg} / \mathrm{kg}$ & SW8240 & 0.10 & ND & ND & ND \\
\hline Xylenes (total), $\mathrm{mg} / \mathrm{kg}$ & SW8240 & 0.10 & ND & ND & ND \\
\hline cis-1,3-Dichloropropene, $\mathrm{mg} / \mathrm{kg}$ & SW8240 & 0.10 & ND & ND & ND \\
\hline
\end{tabular}


Table 17.--Soil-chemical results ${ }^{1}$ of soil samples collected from borehole BH-3, I Tunicipal Solid Waste Landfill Facility, U.S. Army Air Defense Artillery Center and Fort Bliss, El Paso, Texas--Concluded

\begin{tabular}{|c|c|c|c|c|c|}
\hline Parameter and units & $\begin{array}{l}\text { Method } \\
\text { number }\end{array}$ & $\begin{array}{l}\text { Reporting } \\
\text { limit }\end{array}$ & $\begin{array}{l}\text { Soil sample from } \\
5 \text { feet below land } \\
\text { surface } \\
\text { result/qualifier }\end{array}$ & $\begin{array}{l}\text { Soil sample from } \\
20 \text { feet below } \\
\text { land surface } \\
\text { result/qualifier }\end{array}$ & $\begin{array}{l}\text { Soil s } \approx \text { mple from } \\
50 \text { feet below } \\
\text { lard surface } \\
\text { result/qualifier }\end{array}$ \\
\hline trans-1,3-Dichloropropene, $\mathrm{mg} / \mathrm{kg}$ & SW8240 & 0.10 & $\mathrm{ND}$ & $\mathrm{ND}$ & ND \\
\hline trans-1,4-Dichloro-2-butene, $\mathrm{mg} / \mathrm{kg}$ & SW8240 & 0.10 & ND & ND & ND \\
\hline 1,1,1-Trichloroethane, $\mathrm{mg} / \mathrm{kg}$ & SW8240 & 0.10 & ND & ND & ND \\
\hline 1,1,2,2-Tetrachloroethane,mg/kg & SW8240 & 0.10 & ND & ND & $\mathrm{ND}$ \\
\hline 1,1,2-Trichloroethane, $\mathrm{mg} / \mathrm{kg}$ & SW8240 & 0.10 & ND & ND & ND \\
\hline 1,1-Dichloroethane, $\mathrm{mg} / \mathrm{kg}$ & SW8240 & 0.10 & ND & ND & ND \\
\hline 1,1-Dichloroethene, $\mathrm{mg} / \mathrm{kg}$ & SW8240 & 0.10 & ND & $\mathrm{ND}$ & ND \\
\hline 1,2,3-Trichloropropane, $\mathrm{mg} / \mathrm{kg}$ & SW8240 & 0.10 & ND & ND & $\mathrm{ND}$ \\
\hline 1,2-Dichloroethane, $\mathrm{mg} / \mathrm{kg}$ & SW8240 & 0.10 & $\mathrm{ND}$ & ND & $\mathrm{ND}$ \\
\hline 1,2-Dichloroethene (total), $\mathrm{mg} / \mathrm{kg}$ & SW8240 & 0.10 & $\mathrm{ND}$ & ND & $\mathrm{ND}$ \\
\hline 1,2-Dichloropropane, $\mathrm{mg} / \mathrm{kg}$ & SW8240 & 0.10 & $\mathrm{ND}$ & ND & $\mathrm{ND}$ \\
\hline 2-Butanone, $\mathrm{mg} / \mathrm{kg}$ & SW8240 & 0.20 & ND & ND & ND \\
\hline 2-Chloroethyl vinyl ether, $\mathrm{mg} / \mathrm{kg}$ & SW8240 & 0.50 & ND & $\mathrm{ND}$ & ND \\
\hline 2-Hexanone, mg/kg & SW8240 & 0.10 & ND & $\mathrm{ND}$ & ND \\
\hline 4-Methyl-2-pentanone, $\mathrm{mg} / \mathrm{kg}$ & SW8240 & 0.10 & $\mathrm{ND}$ & $\mathrm{ND}$ & ND \\
\hline \multicolumn{6}{|l|}{ Metals: } \\
\hline Arsenic, total, mg $/ \mathrm{kg}$ & SW6010 & 30 & $\mathrm{ND}$ & ND & ND \\
\hline Barium, total, mg $/ \mathrm{kg}$ & SW6010 & 10.0 & 51.3 & 64.8 & 31.4 \\
\hline Cadmium, total, mg $/ \mathrm{kg}$ & SW6010 & 2.0 & $\mathrm{ND}$ & $\mathrm{ND}$ & $\mathrm{ND}$ \\
\hline Chromium, total, $\mathrm{mg} / \mathrm{kg}$ & SW7191 & 4.0 & $3.2 / \mathrm{j}$ & $0.87 / j$ & $1.1 / j$ \\
\hline Cobalt, total, mg/kg & SW6010 & 4.0 & $2.5 / j$ & $1.7 / \mathbf{j}$ & $1.5 / \mathrm{j}$ \\
\hline \multicolumn{6}{|l|}{ Metals-Continued } \\
\hline Copper, total, mg $/ \mathrm{kg}$ & SW6010 & 3.0 & 3.2 & $1.2 / \mathbf{j}$ & $1.3 / \mathrm{j}$ \\
\hline Lead, total, $\mathrm{mg} / \mathrm{kg}$ & SW6010 & 20.0 & $5.9 / \mathrm{j}$ & $\mathrm{ND}$ & $3.6 / j$ \\
\hline Nickel, total, mg/kg & SW6010 & 4.0 & 4.3 & $2.7 / \mathbf{j}$ & $3.0 / j$ \\
\hline Selenium, total, $\mathrm{mg} / \mathrm{kg}$ & SW6010 & 40.0 & $\mathrm{ND} / \mathrm{C}, \mathrm{J}, \mathrm{M}$ & $\mathrm{ND} / \mathrm{C}, \mathrm{J}, \mathrm{M}$ & $\mathrm{ND} / \mathrm{C}, \mathrm{J}, \mathrm{M}$ \\
\hline Nitrite as nitrogen, total, mg $/ \mathrm{kg}$ & E354.1 & 0.050 & $\mathrm{ND} / \mathrm{M}$ & $\mathrm{ND} / \mathrm{M}$ & $\mathrm{ND} / \mathrm{M}$ \\
\hline $\begin{array}{l}\text { Nitrate plus nitrite as nitrogen, total, } \\
\mathrm{mg} / \mathrm{kg}\end{array}$ & $\begin{array}{l}\text { E353.2 } \\
\text { modified }\end{array}$ & 0.50 & $\mathrm{ND} / \mathrm{M}$ & $\mathrm{ND} / \mathrm{M}$ & $\mathrm{ND} / \mathrm{M}$ \\
\hline Soil moisture, percent & D2216 & 0.10 & 5.1 & 3.4 & 4.2 \\
\hline Total petroleum hydrocarbons, $\mathrm{mg} / \mathrm{kg}$ & $\begin{array}{c}\text { SW3550/ } \\
418.1\end{array}$ & 20.0 & ND & ND & $\mathrm{ND}$ \\
\hline
\end{tabular}

${ }^{1}$ Analyses performed by Quanterra Environmental Services, Arvada, Colorado

${ }^{2}$ Method numbers preceded by SW are from:

U.S. Environmental Protection Agency, 1986c

Method numbers preceded by $E$ are from:

U.S. Environmental Protection Agency, 1983, 1986a, b

Method numbers preceded by $D$ are from:

American Society for Testing and Materials, 1919 Race Street, Philadelphia, PA 19103 
Table 18.--Data-qualifier codes used to qualify chemical-analytical data

[TIC, tentatively identified compound]

\footnotetext{
Data-

qualifier

code Definition

A Reported results may be less than the actual value or possibility of a false non-detect because the sample was extracted or analyzed after the required analytical holdingtime limits ${ }^{1}$.

B Associated surrogate-recovery sample results did not meet the frequency or qualitycontrol acceptance criteria.

$\mathrm{b} \quad$ Compound also is detected in the blank (laboratory qualifier code).

C Reported results did not meet the project-reporting limits ${ }^{2}$.

C Reporting limit was not reported by the laboratory.

D Associated field-duplicate sample results did not meet the frequency (discussed in the Quality assurance/quality control and review of analytical data section of this report) or quality-control acceptance criteria ${ }^{3}$.

E Associated equipment blank results did not meet the frequency or quality-control acceptance criteria.

F Associated ambient-conditions blank results did not meet the frequency or quality-control criteria.

G Associated trip blank results did not meet the frequency or quality-control criteria.

g Reporting limit raised due to matrix interference (laboratory qualifier code).

$\mathrm{H}$ Reported value may be biased high because the quality-control results are substantially greater than the quality-control limits ${ }^{4}$.

I Reported value may be biased low because the quality-control results are substantially less than the quality-control limits.

J Associated laboratory duplicate-control sample results did not meet the frequency or quality-control acceptance criteria.

j Result is detected below the reporting limit or is an estimated concentration (laboratory qualifier code).

K Associated laboratory single-control sample results did not meet the frequency or quality-control acceptance criteria.

L Associated method blank results did not meet the frequency or quality-control acceptance criteria.

M Associated matrix spike or matrix-spike duplicate sample results did not meet the frequency or quality-control acceptance criteria.

$\mathrm{N}$ Instrument tuning, calibration, internal standards, or performance results did not meet the frequency or quality-control acceptance criteria.

O Problems with inductively coupled plasma analysis such as interelemental interferences or serial dilution. (This qualifier is to be used only with inorganic data.)

P Reported result was more than the highest calibration of method limits or exceeded the instrument's linear range.

Q Reported result was less than the lowest calibration, target-detection, reporting, or method limits or was below the instrument's linear range.

$\mathrm{R} \quad$ Problems in the sampling or analysis process such as field or laboratory contamination of a sample.

S The sample result (positive or not detected) is considered conditionally rejected because of serious deficiencies in the ability to analyze the sample, or the quality-control acceptance criteria were substantially outside the required limits. Resampling or reanalysis may be necessary to verify the presence or absence of the constituent.
} 
Table 18.--Data-qualifier codes used to qualify chemical-analytical data--Concluded

\begin{tabular}{|c|c|}
\hline $\begin{array}{l}\text { Data- } \\
\text { qualifier } \\
\text { code }\end{array}$ & Definition \\
\hline $\mathrm{T}$ & $\begin{array}{l}\text { The reported positive sample result is considered not reliable because of substantial } \\
\text { contamination in the associated blanks on the basis of the following criteria: (1) concen } \\
\text { tration of analyte that is a common laboratory organic contaminant has a concentration } \\
\text { less than } 10 \text { times the concentration in the associated blank or (2) other analytes have } \\
\text { concentrations less than } 5 \text { times the concentration in the associated blank. }\end{array}$ \\
\hline $\mathrm{t}$ & $\begin{array}{l}\text { Sample diluted because of the concentration of target compounds (laboratory cualifier } \\
\text { code). }\end{array}$ \\
\hline $\mathrm{U}$ & $\begin{array}{l}\text { The reported positive sample result is considered an estimated quantity or question- } \\
\text { able because: (1) there were analysis problems, (2) the quality-control or confirrnation } \\
\text { acceptance criteria were not met, or (3) the amount reported is less than or mor? than } \\
\text { the calibration or method-detection limits }{ }^{5,6} \text {. }\end{array}$ \\
\hline V & $\begin{array}{l}\text { The reported not-detected (ND) sample result is questionable because of analysis prob- } \\
\text { lems or unmet quality-control acceptance criteria. }\end{array}$ \\
\hline W & $\begin{array}{l}\text { The identification of a TIC is questionable and the reported positive result for the TIC is } \\
\text { strictly an estimated value because normal analysis and quality-control acceptance cri- } \\
\text { teria do not apply directly for the reported TIC result. (This data-qualifier code is to be } \\
\text { used only with TIC data.) }\end{array}$ \\
\hline$x$ & $\begin{array}{l}\text { The identification of a TIC is questionable and the reported positive result is con-idered } \\
\text { not reliable because this TIC was also detected in an associated quality-control blank. } \\
\text { (This data-qualifier code is to be used only with TIC data.) }\end{array}$ \\
\hline$Y$ & $\begin{array}{l}\text { The identification of a TIC is questionable and the reported positive result is con ridered } \\
\text { as conditionally rejected because this TIC is considered a common laboratory contami- } \\
\text { nant. (This data-qualifier code is to be used only with TIC data.) }\end{array}$ \\
\hline $\mathrm{Z}$ & $\begin{array}{l}\text { This data qualifier code is used for specific analytical results that have data-quality } \\
\text { problems not covered or represented in this list. If this code is used, some explanation } \\
\text { is needed to describe the specific data-quality problem. }\end{array}$ \\
\hline
\end{tabular}

${ }^{1}$ Holding time - period of time during which a sample can be stored after collection and preservation. Holding-time limits are listed in table 1.5.2.1 of the Sampling and Analysis Plan for Ground-Water Monitoring at the Municipal Solid Waste Landfill Facility, U.S. Army Air Defense Artillery Center and Fort Bliss, El Paso, Texas, Final (U.S. Geological Survey, written commun., March 1995)

${ }^{2}$ Project-reporting limit - the minimum signal level required to quantitatively identify a specific analyte by a specific procedure at a confidence level that is greater than 97 percent. Limits are listed in table 1.8.2.1 of the Sampling and Analysis Plan for Ground-Water Monitoring at the Municipal Solid Waste Landfill Facility, U.S. Army Air Defense Artillery Center and Fort Bliss, El Paso, Texas, Final (U.S. Geological Survey, written commun., March 1995)

${ }^{3}$ Quality-control acceptance criteria - predefined requirements established to monitor that the data gene-ated are precise and accurate. Criteria are listed in table 1.8.3.1 of the Sampling and Analysis Plan for GroundWater Monitoring at the Municipal Solid Waste Landfill Facility, U.S. Army Air Defense Artillery Center and Fort Bliss, El Paso, Texas, Final (U.S. Geological Survey, written commun., March 1995)

${ }^{4}$ Quality-control limits - limits for assessing accuracy through the use of matrix-spike and matrix-spike duplicate samples. Limits are listed in table 1.13.2.1 of the Sampling and Analysis Plan for Ground-V'ater Monitoring at the Municipal Solid Waste Landfill Facility, U.S. Army Air Defense Artillery Center and Fort Bliss, El Paso, Texas, Final (U.S. Geological Survey, written commun., March 1995)

${ }^{5}$ Calibration limit - the frequency of calibration and calibration verification and the concentration of calibration standards are determined by the manufacturer's guidelines, the analytical method, or the requirements of special contracts

${ }^{6}$ Method-detection limit - minimum concentration of a substance that can be measured and reported using a specific method 
Table 19.--Analytical methods used ${ }^{1}$ for physical properties, total organic carbon, and $\mathrm{pH}$ analysis of soil samples collected from boreholes BH-3 and MSWLF03, U.S. Army Air Defense Artillery Center and Fort Bliss, El Paso, Texas

\begin{tabular}{|c|c|}
\hline Parameter and unit & Method number or reference ${ }^{2}$ \\
\hline Moisture content, percent & ASTM D 2216-90 \\
\hline Bulk density, grams per cubic centimeter & Klute (1986, p. 363-367) \\
\hline Porosity, percent & Klute (1986, p. 444-445) \\
\hline $\begin{array}{l}\text { Saturated hydraulic conductivity, centimeters per second } \\
\text { Constant head } \\
\text { Falling head }\end{array}$ & $\begin{array}{l}\text { ASTM D 2434-68(74) } \\
\text { Klute (1986, p. 700-703) }\end{array}$ \\
\hline Total organic carbon, milligrams per kilogram & DISC-860 (c-analyzer) \\
\hline $\mathrm{pH}$, standard units & EPA 600/2-78-054 Method 3.2.17 \\
\hline $\begin{array}{l}\text { Moisture retention characteristics, } \\
\text { Pressure head, per centimeter water } \\
\text { Moisture content, percent by volume } \\
\text { Hanging column } \\
\text { Pressure plate extractor } \\
\text { Thermocouple psychrometer }\end{array}$ & $\begin{array}{l}\text { Klute (1986, p. 637-639) } \\
\text { ASTM D 2325-68(81) } \\
\text { Klute (1986, p. 597-618), Operators' man- } \\
\text { ual for the SC-10A thermocouple psy- } \\
\text { chrometer sample chamber } \\
\text { (manufactured by Decagon Devices, } \\
\text { Inc., Pullman, Wash.) }\end{array}$ \\
\hline Saturated salt-equilibration & \\
\hline $\begin{array}{l}\text { Calculated parameters (relating hydraulic conductibity to } \\
\text { saturation) } \\
\text { van Genuchten } \\
\text { Brooks and Corey }\end{array}$ & $\begin{array}{l}\text { U.S. Environmental Protection Agency } \\
\text { (1991) } \\
\text { van Genuchten (1980) } \\
\text { Brooks and Corey (1966) }\end{array}$ \\
\hline $\begin{array}{l}\text { Particle-size characteristics } \\
\text { Sieve } \\
\text { Hydrometer }\end{array}$ & $\begin{array}{l}\text { ASTM D 422-63(90) } \\
\text { ASTM D 422-63(90) }\end{array}$ \\
\hline
\end{tabular}

${ }^{1}$ Analyses performed by Daniel B. Stephens \& Associates, Inc., Albuquerque, N. Mex.

${ }^{2}$ Method numbers preceded by ASTM D are from:

Annual Book of ASTM Standards, American Society for Testing and Materials (ASTM), 1919 Race Street, Philadelphia, PA 19103 


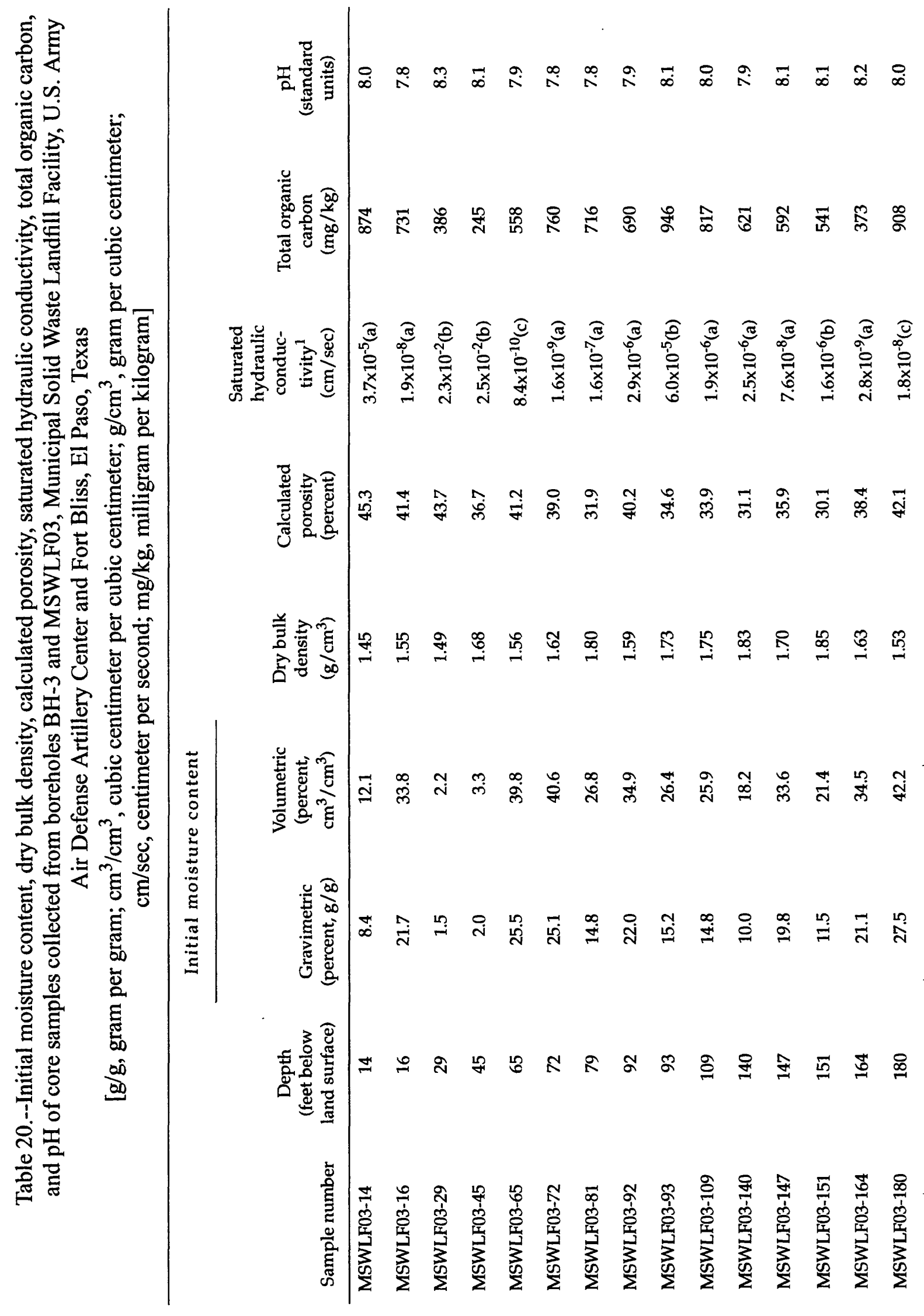




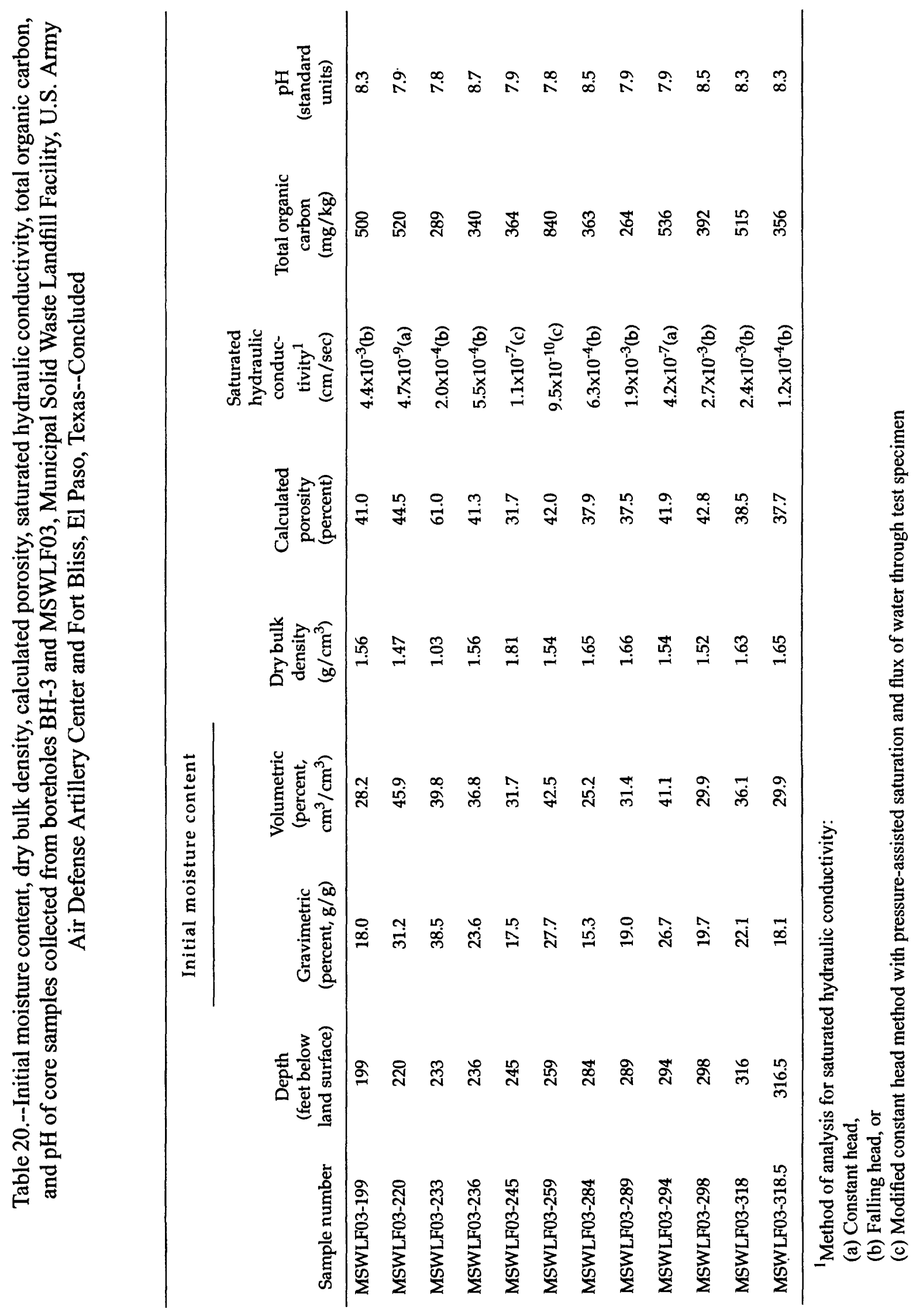


Table 21.--Moisture content, measured at various pressure heads, of core samples collected from boreholes BH-3 and MSWLF03, Municipal Solid Waste Landfill Facility, U.S. Army Air Defense Artillery Center and Fort Bliss, El Paso, Texas

\begin{tabular}{|c|c|c|c|}
\hline Sample number & $\begin{array}{c}\text { Depth } \\
\text { (feet below } \\
\text { land surface) }\end{array}$ & $\begin{array}{c}\text { Pressure head }{ }^{1} \\
\text { (per centimeter water) }\end{array}$ & $\begin{array}{l}\text { Moisture content } \\
\text { (percent by volume, } \\
\text { cubic centimeter per } \\
\text { cubic centimeter) }\end{array}$ \\
\hline MSWLF03-14 & 14 & $\begin{array}{r}0(\mathrm{a}) \\
34(\mathrm{a}) \\
107(\mathrm{a}) \\
347(\mathrm{~b}) \\
1040(\mathrm{~b}) \\
17449(\mathrm{c}) \\
861134(\mathrm{~d})\end{array}$ & \begin{tabular}{r|}
47.3 \\
44.5 \\
41.0 \\
31.4 \\
21.2 \\
11.2 \\
4.0
\end{tabular} \\
\hline MSWLF03-16 & 16 & $\begin{array}{r}0(a) \\
54(a) \\
108(a) \\
1020(b) \\
3059(b) \\
23731(\mathrm{c}) \\
861134(d)\end{array}$ & $\begin{array}{l}49.5 \\
46.6 \\
45.1 \\
42.1 \\
40.2 \\
32.5 \\
11.4\end{array}$ \\
\hline MSWLF03-29 & 29 & $\begin{array}{r}0(a) \\
15(a) \\
35(a) \\
92(a) \\
224(b) \\
1020(b) \\
18540(\mathrm{c}) \\
861134(d)\end{array}$ & $\begin{array}{r}35.5 \\
34.8 \\
19.5 \\
7.0 \\
5.8 \\
4.1 \\
-.0 \\
0.4\end{array}$ \\
\hline MSWLF03-45 & 45 & $\begin{array}{r}0(\mathrm{a}) \\
15(\mathrm{a}) \\
32(\mathrm{a}) \\
70(\mathrm{a}) \\
1020(\mathrm{~b}) \\
15093(\mathrm{~b})(\mathrm{c}) \\
861134(\mathrm{~d})\end{array}$ & $\begin{array}{r}26.0 \\
25.1 \\
11.4 \\
4.7 \\
4.1 \\
\therefore .4 \\
1.2\end{array}$ \\
\hline MSWLF03-65 & 65 & $\begin{array}{r}0(a) \\
57(a) \\
107(a) \\
861134(d)\end{array}$ & $\begin{array}{l}51.7 \\
5 C .4 \\
5 C .1 \\
12.2\end{array}$ \\
\hline MSWLF03-72 & 72 & $\begin{array}{r}0(a) \\
57(a) \\
102(a) \\
846(b) \\
3059(b) \\
28585(\mathrm{c}) \\
861134(d)\end{array}$ & $\begin{array}{l}47.0 \\
46.3 \\
46.2 \\
4 . .8 \\
4 C .4 \\
2 C .7 \\
13.2\end{array}$ \\
\hline
\end{tabular}


Table 21.--Moisture content, measured at various pressure heads, of core samples collected from boreholes BH-3 and MSWLF03, Municipal Solid Waste Landfill Facility, U.S. Army Air Defense Artillery Center and Fort Bliss, El Paso, Texas--Continued

\begin{tabular}{|c|c|c|c|}
\hline Sample number & $\begin{array}{c}\text { Depth } \\
\text { (feet below } \\
\text { land surface) }\end{array}$ & $\begin{array}{c}\text { Pressure head }{ }^{1} \\
\text { (per centimeter water) }\end{array}$ & $\begin{array}{l}\text { Moisture content } \\
\text { (percent by volume, } \\
\text { cubic centimeter per } \\
\text { cubic centimeter) }\end{array}$ \\
\hline MSWLF03-81 & 79 & $\begin{array}{r}0(\mathrm{a}) \\
28(\mathrm{a}) \\
130(\mathrm{a}) \\
540(\mathrm{~b}) \\
979(\mathrm{~b}) \\
17632(\mathrm{c}) \\
853025(\mathrm{~d})\end{array}$ & \begin{tabular}{r|}
35.2 \\
34.8 \\
33.8 \\
32.1 \\
30.8 \\
22.1 \\
7.0
\end{tabular} \\
\hline MSWLF03-92 & 92 & $\begin{array}{r}0(\mathrm{a}) \\
43(\mathrm{a}) \\
144(\mathrm{a}) \\
530(\mathrm{~b}) \\
1020(\mathrm{~b}) \\
15093(\mathrm{~b})(\mathrm{c}) \\
861134(\mathrm{~d})\end{array}$ & \begin{tabular}{r|}
39.4 \\
38.1 \\
31.4 \\
21.8 \\
19.9 \\
15.4 \\
3.2
\end{tabular} \\
\hline MSWLF03-93 & 93 & $\begin{array}{r}0(\mathrm{a}) \\
23(\mathrm{a}) \\
59(\mathrm{a}) \\
134(\mathrm{a}) \\
551(\mathrm{~b}) \\
28809(\mathrm{c}) \\
853025(\mathrm{~d})\end{array}$ & $\begin{array}{r}34.9 \\
33.3 \\
30.3 \\
20.3 \\
13.9 \\
7.8 \\
2.1\end{array}$ \\
\hline MSWLF03-109 & 109 & $\begin{array}{r}0(a) \\
43(a) \\
160(a) \\
347(b) \\
1040(b) \\
27188(\mathrm{c}) \\
861134(d)\end{array}$ & \begin{tabular}{r|}
31.9 \\
30.1 \\
25.7 \\
23.4 \\
19.4 \\
11.2 \\
2.8
\end{tabular} \\
\hline MSWLF03-140 & 140 & $\begin{array}{r}0(a) \\
28(a) \\
128(a) \\
520(b) \\
846(b) \\
14848(\mathrm{c}) \\
853025(d)\end{array}$ & \begin{tabular}{r|}
31.9 \\
31.0 \\
29.4 \\
22.7 \\
21.3 \\
13.7 \\
5.7
\end{tabular} \\
\hline MSWLF03-147 & 147 & $\begin{array}{r}0(\mathrm{a}) \\
51(\mathrm{a}) \\
105(\mathrm{a}) \\
1050(\mathrm{~b}) \\
17071(\mathrm{c}) \\
853025(\mathrm{~d})\end{array}$ & $\begin{array}{r}42.4 \\
38.9 \\
38.3 \\
36.0 \\
29.9 \\
9.8\end{array}$ \\
\hline
\end{tabular}


Table 21.--Moisture content, measured at various pressure heads, of core samples collected from boreholes BH-3 and MSWLF03, Municipal Solid Waste Landfill Facility, U.S. Army Air Defense Artillery Center and Fort Bliss, El Paso, Texas--Continued

\begin{tabular}{|c|c|c|c|}
\hline Sample number & $\begin{array}{c}\text { Depth } \\
\text { (feet below } \\
\text { land surface) }\end{array}$ & $\begin{array}{l}\text { Pressure head }{ }^{1} \\
\text { (per centimeter water) }\end{array}$ & $\begin{array}{l}\text { Moisture cortent } \\
\text { (percent by volume, } \\
\text { cubic centimet ?r per } \\
\text { cubic centimeter) }\end{array}$ \\
\hline MSWLF03-151 & 151 & $\begin{array}{r}0(\mathrm{a}) \\
26(\mathrm{a}) \\
130(\mathrm{a}) \\
520(\mathrm{~b}) \\
846(\mathrm{~b}) \\
14838(\mathrm{c}) \\
853025(\mathrm{~d})\end{array}$ & \begin{tabular}{r|}
34.3 \\
31.4 \\
28.7 \\
24.7 \\
23.8 \\
14.9 \\
4.2
\end{tabular} \\
\hline MSWLF03-164 & 164 & $\begin{array}{r}0(a) \\
55(a) \\
104(a) \\
846(b) \\
3059(b) \\
14685(c) \\
861134(d)\end{array}$ & \begin{tabular}{r|}
38.7 \\
37.7 \\
37.5 \\
35.1 \\
31.3 \\
22.6 \\
7.0
\end{tabular} \\
\hline MSWLF03-180 & 180 & $\begin{array}{r}0(a) \\
51(a) \\
106(a) \\
1020(b) \\
3080(b) \\
15103(c) \\
853025(d)\end{array}$ & $\begin{array}{r}49.2 \\
46.1 \\
45.3 \\
42.1 \\
40.0 \\
26.1 \\
8.1\end{array}$ \\
\hline MSWLF03-199 & 199 & $\begin{array}{r}0(a) \\
13(a) \\
45(a) \\
61(a) \\
224(b) \\
1020(b) \\
20661(c) \\
861134(d)\end{array}$ & \begin{tabular}{r|}
34.6 \\
32.3 \\
28.2 \\
19.7 \\
11.5 \\
8.3 \\
3.9 \\
1.7
\end{tabular} \\
\hline MSWLF03-220 & 220 & $\begin{array}{r}0(a) \\
54(a) \\
105(a) \\
846(b) \\
3059(b) \\
18061(c) \\
861134(d)\end{array}$ & $\begin{array}{l}50.6 \\
48.2 \\
47.7 \\
46.6 \\
45.2 \\
39.8 \\
12.1\end{array}$ \\
\hline MSWLF03-233 & 233 & $\begin{array}{r}0(a) \\
23(a) \\
37(a) \\
131(a) \\
551(b) \\
25536(\mathrm{c}) \\
853025(\mathrm{~d})\end{array}$ & $\begin{array}{r}57.7 \\
56.0 \\
48.4 \\
33.0 \\
20.9 \\
7.5 \\
2.6\end{array}$ \\
\hline
\end{tabular}


Table 21.--Moisture content, measured at various pressure heads, of core samples collected from boreholes BH-3 and MSWLF03, Municipal Solid Waste Landfill Facility, U.S. Army Air Defense Artillery Center and Fort Bliss, El Paso, Texas--Continued

\begin{tabular}{|c|c|c|c|}
\hline Sample number & $\begin{array}{c}\text { Depth } \\
\text { (feet below } \\
\text { land surface) }\end{array}$ & $\begin{array}{l}\text { Pressure head }{ }^{1} \\
\text { (per centimeter water) }\end{array}$ & $\begin{array}{l}\text { Moisture content } \\
\text { (percent by volume, } \\
\text { cubic centimeter per } \\
\text { cubic centimeter) }\end{array}$ \\
\hline MSWLF03-236 & 236 & $\begin{array}{r}0(\mathrm{a}) \\
28(\mathrm{a}) \\
48(\mathrm{a}) \\
224(\mathrm{~b}) \\
1020(\mathrm{~b}) \\
28554(\mathrm{c}) \\
861134(\mathrm{~d})\end{array}$ & $\begin{array}{r}39.9 \\
38.3 \\
33.1 \\
27.5 \\
21.5 \\
2.8 \\
1.2\end{array}$ \\
\hline MSWLF03-245 & 245 & $\begin{array}{r}0(a) \\
28(a) \\
128(a) \\
510(b) \\
1020(b) \\
17908(c) \\
853025(d)\end{array}$ & $\begin{array}{r}34.9 \\
33.5 \\
32.0 \\
31.1 \\
30.4 \\
17.6 \\
5.3\end{array}$ \\
\hline MSWLF03-259 & 259 & $\begin{array}{c}0(a) \\
53(a) \\
105(a) \\
861134(d)\end{array}$ & $\begin{array}{l}49.4 \\
46.3 \\
45.6 \\
13.5\end{array}$ \\
\hline MSWLF03-284 & 284 & $\begin{array}{r}0(a) \\
24(a) \\
45(a) \\
224(b) \\
1020(b) \\
21732(c) \\
861134(d)\end{array}$ & $\begin{array}{r}37.3 \\
33.3 \\
21.9 \\
14.8 \\
11.9 \\
2.6 \\
1.5\end{array}$ \\
\hline MSWLF03-289 & 289 & $\begin{array}{r}0(a) \\
13(a) \\
38(a) \\
73(a) \\
203(a) \\
21742(\mathrm{c}) \\
853025(d)\end{array}$ & $\begin{array}{r}37.3 \\
36.1 \\
32.2 \\
10.2 \\
6.6 \\
2.6 \\
0.9\end{array}$ \\
\hline MSWLF03-294 & 294 & $\begin{array}{r}0(a) \\
22(a) \\
129(a) \\
551(b) \\
1050(b) \\
22619(\mathrm{c}) \\
853025(d)\end{array}$ & $\begin{array}{l}50.1 \\
48.1 \\
45.4 \\
43.7 \\
42.6 \\
33.9 \\
12.1\end{array}$ \\
\hline
\end{tabular}


Table 21.--Moisture content, measured at various pressure heads, of core samples collected from boreholes BH-3 and MSWLF03, Municipal Solid Waste Landfill Facility, U.S. Army Air Defense Artillery Center and Fort Bliss, El Paso, Texas--Concluded

\begin{tabular}{|c|c|c|c|}
\hline Sample number & $\begin{array}{c}\text { Depth } \\
\text { (feet below } \\
\text { land surface) }\end{array}$ & $\begin{array}{c}\text { Pressure head }{ }^{1} \\
\text { (per centimeter water) }\end{array}$ & $\begin{array}{l}\text { Moisture contint } \\
\text { (percent by volume, } \\
\text { cubic centimete:- per } \\
\text { cubic centimeter) }\end{array}$ \\
\hline MSWLF03-298 & 298 & $\begin{array}{r}0(a) \\
12(a) \\
41(a) \\
70(a) \\
204(b) \\
1020(b) \\
22599(\mathrm{c}) \\
861134(d)\end{array}$ & \begin{tabular}{|r|}
35.3 \\
34.1 \\
30.4 \\
14.6 \\
10.6 \\
10.0 \\
1.9 \\
0.9
\end{tabular} \\
\hline MSWLF03-318 & 316 & $\begin{array}{r}0(a) \\
15(a) \\
43(a) \\
73(a) \\
1020(b) \\
15093(b)(c) \\
861134(d)\end{array}$ & $\begin{array}{r}39.7 \\
38.2 \\
35.2 \\
15.4 \\
8.7 \\
5.9 \\
1.3\end{array}$ \\
\hline MSWLF03-318.5 & 316.5 & $\begin{array}{r}0(a) \\
22(a) \\
47(a) \\
136(a) \\
530(b) \\
17153(\mathrm{c}) \\
853025(d)\end{array}$ & $\begin{array}{r}35.4 \\
33.9 \\
27.9 \\
17.1 \\
14.3 \\
3.5 \\
1.0\end{array}$ \\
\hline
\end{tabular}

${ }^{1}$ Method of analysis:
(a) Hanging column;
(b) Pressure plate extractor;
(c) Thermocouple psychrometer; or
(d) Saturated salt equilibration 

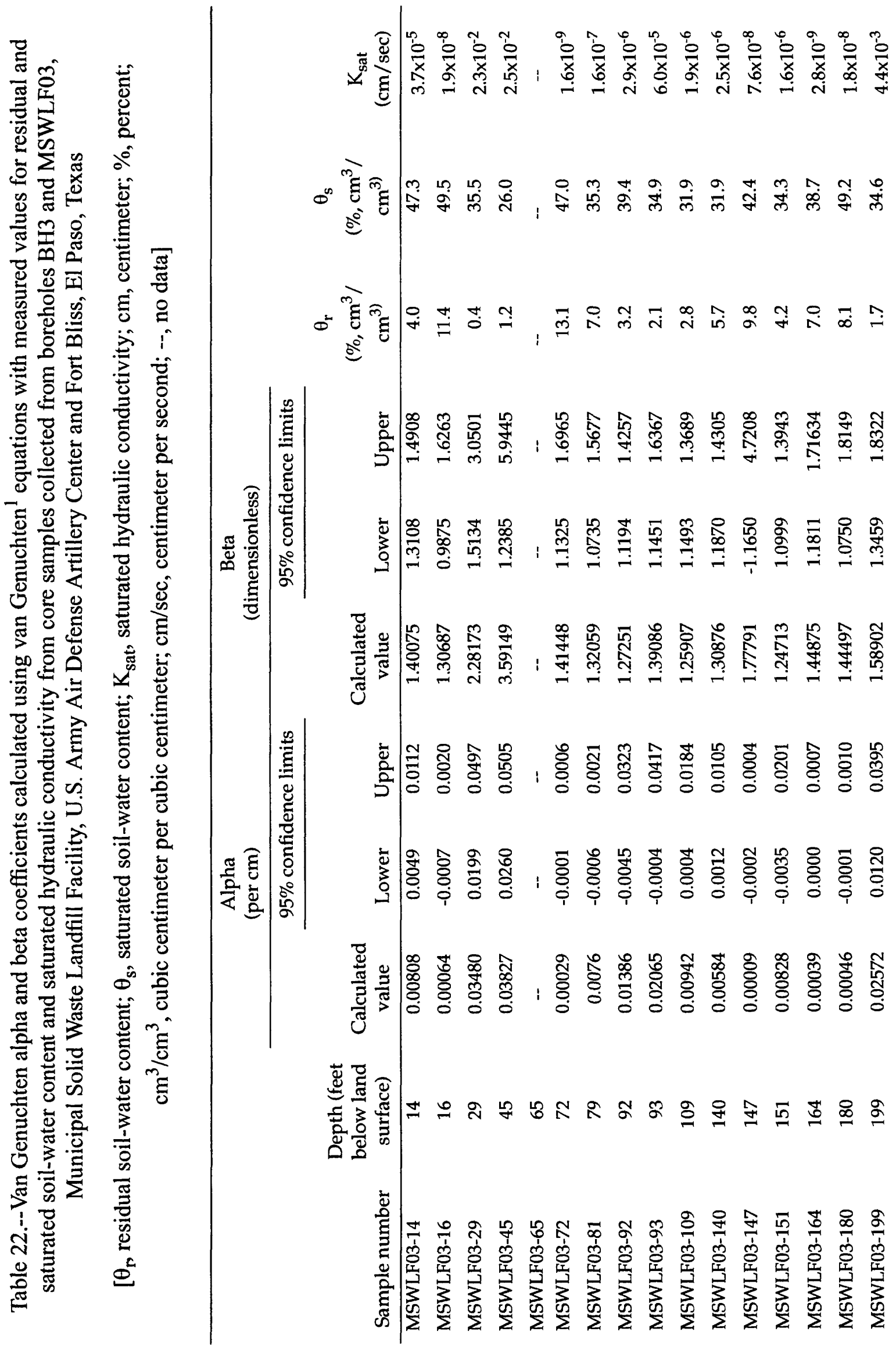
믈

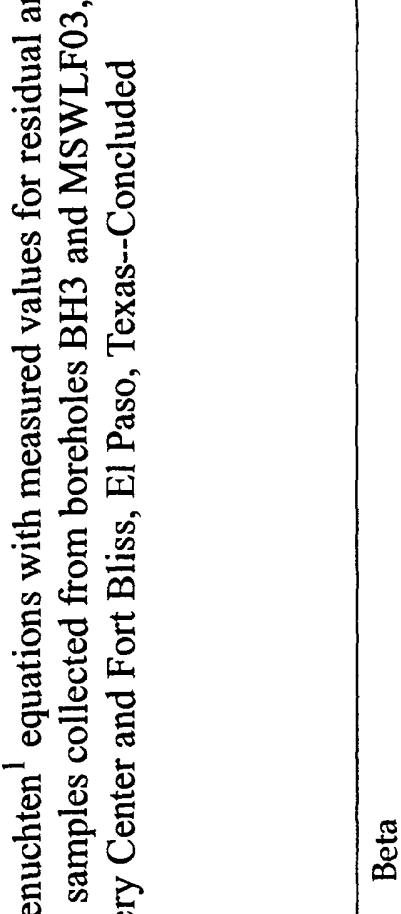

8

.

of

.

政

苛导娄

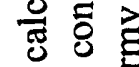

은

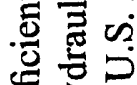

\&

흥

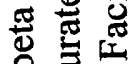

焉

ฮ

흥 휼

छ ठี

등

部

专

ते

告营

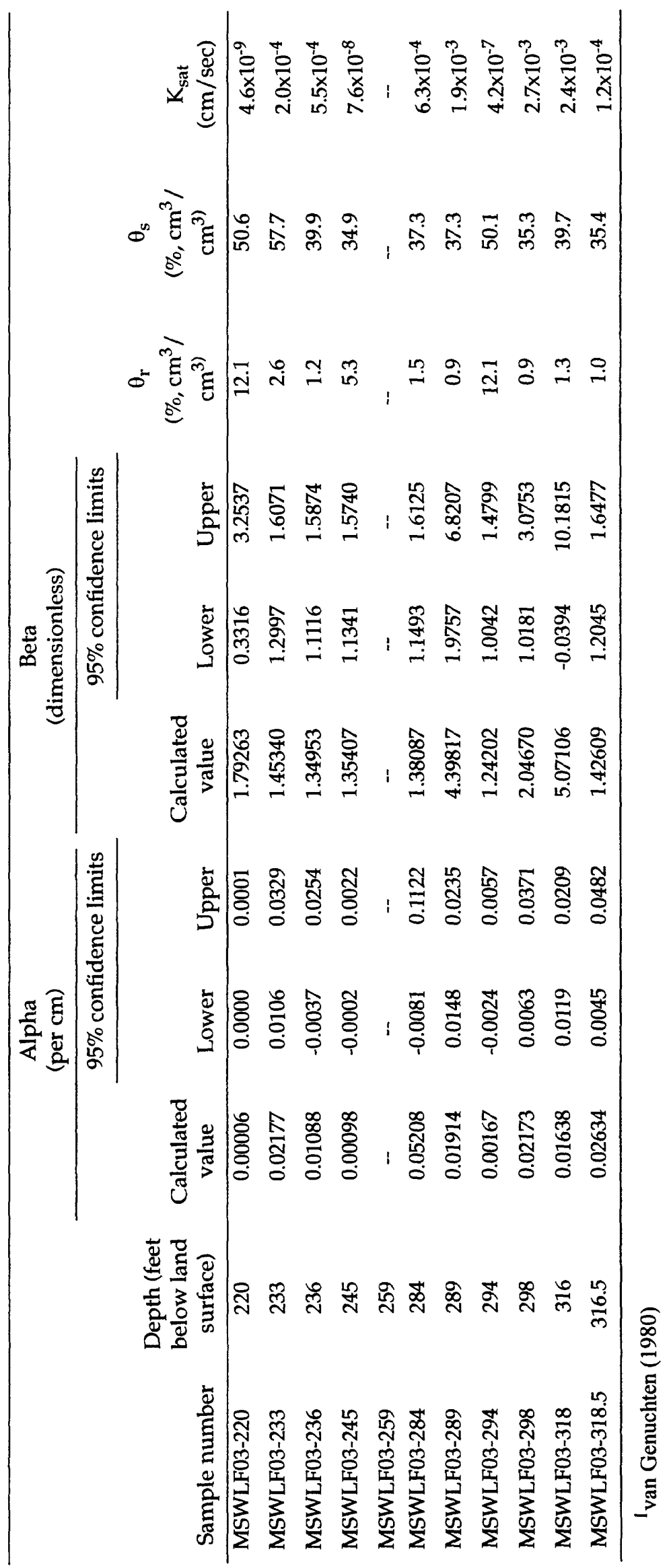

63 
Table 23.--Air entry value and Brooks and Corey exponent derived for core samples collectec' from boreholes BH-3 and MSWLF03, Municipal Solid Waste Landfill Facility, U.S. Army Air Defense Artillery Center and Fort Bliss, El Paso, Texas

\begin{tabular}{|c|c|c|c|}
\hline Sample number & $\begin{array}{c}\text { Depth } \\
\text { (feet below land } \\
\text { surface) }\end{array}$ & $\begin{array}{l}\text { Air entry value } \\
\text { (per centimeter) }\end{array}$ & $\begin{array}{l}\text { Brooks and Corey } \\
\text { exponent }\end{array}$ \\
\hline MSWLF03-14 & 14 & 124 & 0.40075 \\
\hline MSWLF03-16 & 16 & 1,563 & 0.30687 \\
\hline MSWLF03-29 & 29 & 29 & 1.28173 \\
\hline MSWLF03-45 & 45 & 26 & 2.59149 \\
\hline MSWLF03-65 & 65 & - & - \\
\hline MSWLF03-72 & 72 & 3,448 & 0.41448 \\
\hline MSWLF03-81 & 79 & 1,316 & 0.32059 \\
\hline MSWLF03-92 & 92 & 72 & 0.27251 \\
\hline MSWLF03-93 & 93 & 48 & 0.39086 \\
\hline MSWLF03-109 & 109 & 106 & 0.25907 \\
\hline MSWLF03-140 & 140 & 171 & 0.30876 \\
\hline MSWLF03-147 & 147 & 11,111 & 0.77791 \\
\hline MSWLF03-151 & 151 & 121 & 0.24713 \\
\hline MSWLF03-164 & 164 & 2,564 & 0.44875 \\
\hline MSWLF03-180 & 180 & 2,174 & 0.44497 \\
\hline MSWLF03-199 & 199 & 39 & 0.58902 \\
\hline MSWLF03-220 & 220 & 16,667 & 0.79263 \\
\hline MSWLF03-233 & 233 & 46 & 0.4534 \\
\hline MSWLF03-236 & 236 & 92 & 0.34953 \\
\hline MSWLF03-245 & 245 & 1,020 & 0.35407 \\
\hline MSWLF03-259 & 259 & - & - \\
\hline MSWLF03-284 & 284 & 19 & 0.38087 \\
\hline MSWLF03-289 & 289 & 52 & 3.39817 \\
\hline MSWLF03-294 & 294 & 599 & 0.24202 \\
\hline MSWLF03-298 & 298 & 46 & 1.04670 \\
\hline MSWLF03-318 & 316 & 61 & 4.07106 \\
\hline MSWLF03-318.5 & 316.5 & 38 & 0.42609 \\
\hline
\end{tabular}

${ }^{1}$ Brooks and Corey (1966) 


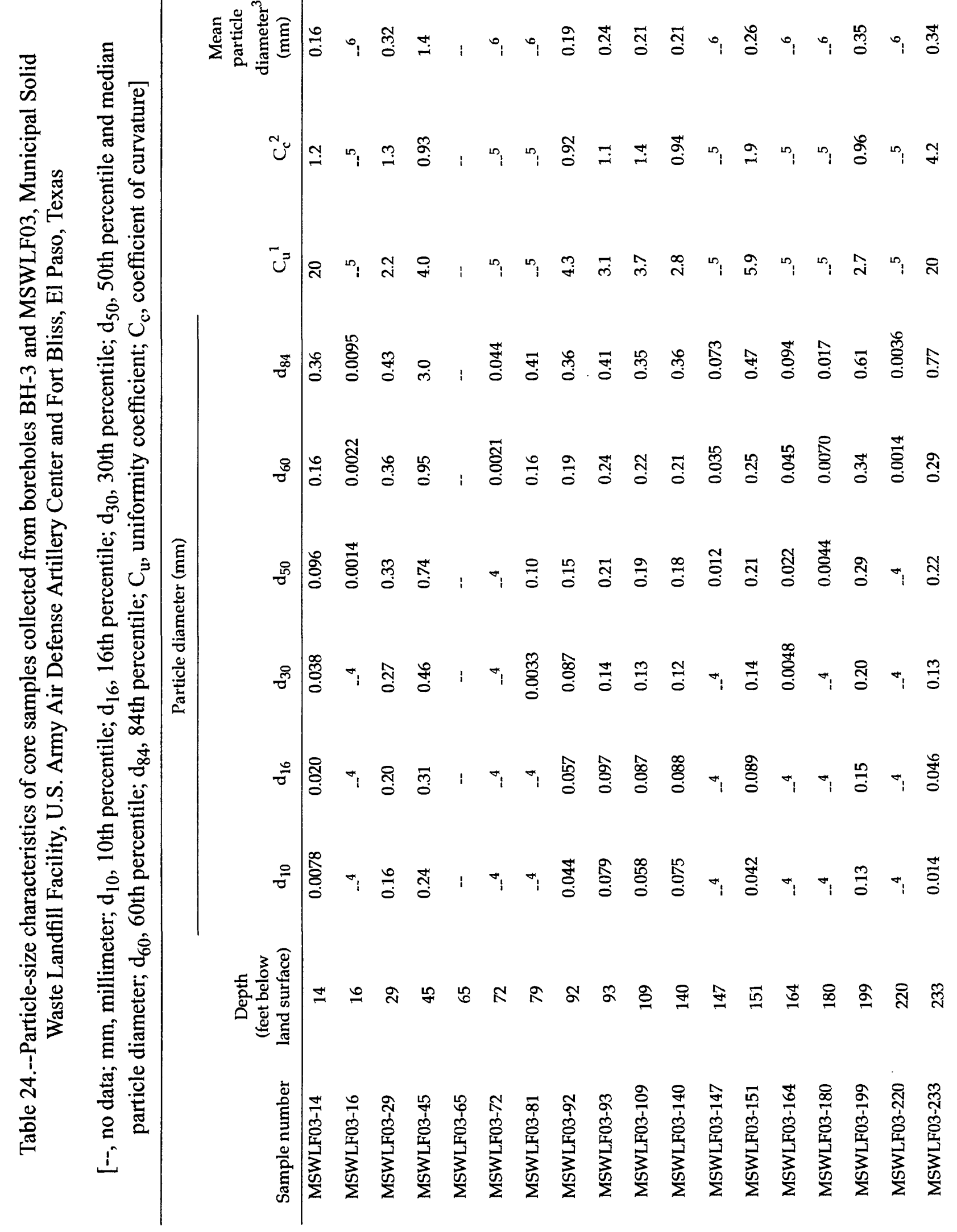


흥

풍

兰

造

$\stackrel{\mathscr{I}}{\mathscr{D}}$

$\bar{D}$

\&

을

$\triangle$

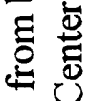

엉

过

은

कै

हี

号:

4

. 라

.

อ

胥

这

讷

i $\equiv$

응

롱

可

ते

尊

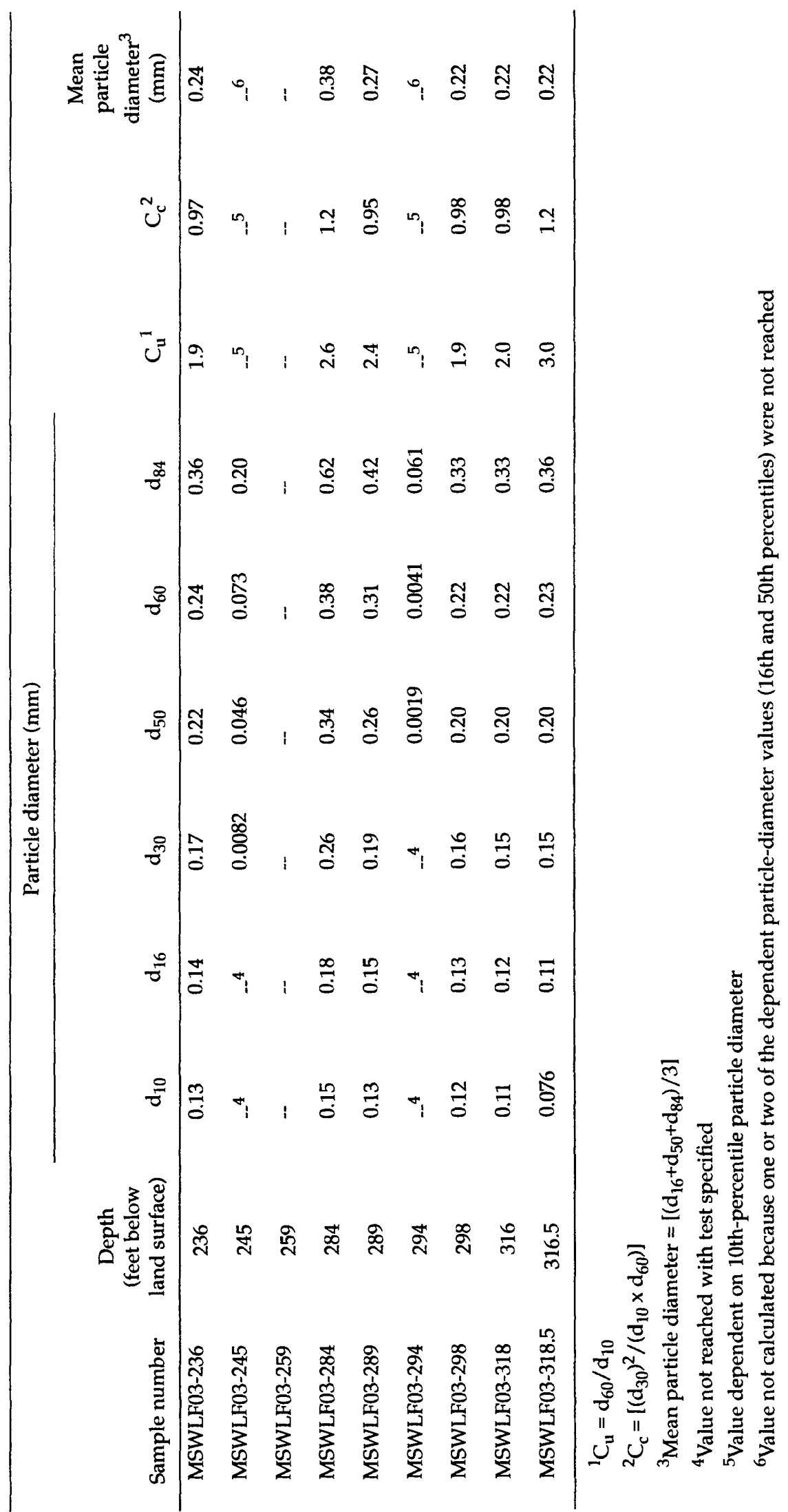


Table 25.--Analytical methods used ${ }^{1}$ for physical analyses of soil samples collected from the landfill cover, Municipal Solid Waste Landfill Facility, U.S. Army Air Defense Artillery Center and Fort Bliss, El Paso, Texas

\begin{tabular}{ll}
\hline \multicolumn{1}{c}{ Parameter and unit } & \multicolumn{1}{c}{ Method number or referenco } \\
\hline Moisture content, percent & ASTM D 2216-90 \\
Bulk density, grams per cubic centimeter & Klute (1986, p. 363-367) \\
Porosity, percent & Klute (1986, p. 444-445) \\
Moisture retention characteristics, & \\
Pressure head, per centimeter water & \\
Moisture content, percent by volume & \\
Pressure plate extractor & \\
Thermocouple psychrometer & ASTM D 2325-68(81) \\
& Klute (1986, p. 597-618), Operato's \\
& manual for the SC-10A thermorou- \\
& ple psychrometer sample chamber \\
(manufactured by Decagon Devices, & Inc., Pullman, Wash.) \\
Infiltration rate, centimeters per second & Perroux and White (1988) \\
& Elrick and others (1988) \\
& Ankeny and others (1988; 1989) \\
& Prieksat and others (1991) \\
Hydraulic conductivity (calculated from unconfined & Wooding (1968) \\
infiltration data), centimeters per second & Ankeny and others (1991) \\
& Elrick and others (1988) \\
\hline
\end{tabular}

\footnotetext{
${ }^{1}$ Analyses performed by Daniel B. Stephens \& Associates, Inc., Albuquerque, N. Mex.

${ }^{2}$ Method numbers preceded by ASTM D are from:

Annual Book of ASTM Standards, American Society for Testing and Materials (ASTM), 1919 Race Street, Philadelphia, PA 19103
} 
Table 26.--Initial moisture content, dry bulk density, and calculated porosity of soil samples collected from the landfill cover, Municipal Solid Waste Landfill Facility, U.S. Army Air Defense Artillery Center and Fort Bliss, El Paso, Texas

[g/g, gram per gram; $\mathrm{cm}^{3} / \mathrm{cm}^{3}$, cubic centimeter per cubic centimeter; $\mathrm{g} / \mathrm{cm}^{3}$, gram per cubic centimeter]

\begin{tabular}{ccccc}
\hline & \multicolumn{2}{c}{ Initial moisture content } & & \\
\cline { 2 - 3 } Sample number & $\begin{array}{c}\text { Gravimetric } \\
\text { (percent, g/g) }\end{array}$ & $\begin{array}{c}\text { Volumetric } \\
\text { (percent, } \\
\left.\mathrm{cm}^{3} / \mathrm{cm}^{3}\right)\end{array}$ & $\begin{array}{c}\text { Dry bulk } \\
\text { density } \\
\left(\mathrm{g} / \mathrm{cm}^{3}\right)\end{array}$ & $\begin{array}{c}\text { Calculated } \\
\text { porosity } \\
\text { (percent) }\end{array}$ \\
\hline Site 1, Rep 1 & 14.4 & 25.1 & 1.74 & 34.4 \\
Site 1, Rep 2 & 12.5 & 22.3 & 1.79 & 32.5 \\
Site 2, Rep 1 & 11.7 & 20.5 & 1.75 & 34.0 \\
Site 2, Rep 2 & 8.2 & 13.8 & 1.68 & 36.6 \\
Site 3, Rep 1 & 16.6 & 29.4 & 1.77 & 33.3 \\
Site 3, Rep 2 & 10.5 & 18.0 & 1.71 & 35.5 \\
Site 4, Rep 1 & 17.7 & 29.7 & 1.68 & 36.5 \\
Site 4, Rep 2 & 17.7 & 28.9 & 1.63 & 38.4 \\
Site 5, Rep 1 & 13.8 & 23.2 & 1.68 & 36.8 \\
Site 5, Rep 2 & 12.2 & 21.4 & 1.76 & 33.6 \\
\hline
\end{tabular}


Table 27.--Moisture content, measured at various pressure heads, of soil samples collected from the landfill cover, Municipal Solid Waste Landfill Facilit:; U.S. Army Air Defense Artillery Center and Fort Bliss, El Paso, Texas

[cm, centimeter; $\mathrm{cm}^{3} / \mathrm{cm}^{3}$, cubic centimeter per cubic centimeter]

\begin{tabular}{|c|c|c|}
\hline Sample number & $\begin{array}{l}\text { Pressure head }{ }^{1} \\
\text { (per cm water) }\end{array}$ & $\begin{array}{c}\text { Moisture } \\
\text { content } \\
\text { (percent, } \\
\mathrm{cm}^{3} / \mathrm{cm}^{3} \text { ) }\end{array}$ \\
\hline Site $1, \operatorname{Rep} 1$ & $\begin{array}{r}0(a) \\
337(a) \\
26617(b)\end{array}$ & $\begin{array}{r}35.0 \\
20.0 \\
9.1\end{array}$ \\
\hline Site 1, Rep 2 & $\begin{array}{r}0(a) \\
337(a) \\
17643(b)\end{array}$ & $\begin{array}{r}35.2 \\
20.2 \\
9.8\end{array}$ \\
\hline Site $2, \operatorname{Rep} 1$ & $\begin{array}{r}0(a) \\
337(a) \\
24781(b)\end{array}$ & $\begin{array}{r}33.8 \\
20.3 \\
9.3\end{array}$ \\
\hline Site $2, \operatorname{Rep} 2$ & $\begin{array}{r}0(a) \\
337(a) \\
21092(b)\end{array}$ & $\begin{array}{r}28.3 \\
12.7 \\
8.7\end{array}$ \\
\hline Site $3, \operatorname{Rep} 1$ & $\begin{array}{r}0(a) \\
337(a) \\
18662(b)\end{array}$ & $\begin{array}{l}41.7 \\
29.1 \\
11.0\end{array}$ \\
\hline Site 3 , Rep 2 & $\begin{array}{r}0(a) \\
337(a) \\
21518(b)\end{array}$ & $\begin{array}{r}31.7 \\
15.8 \\
8.6\end{array}$ \\
\hline Site $4, \operatorname{Rep} 1$ & $\begin{array}{r}0(a) \\
337(a) \\
15195(b)\end{array}$ & $\begin{array}{l}41.0 \\
27.8 \\
10.0\end{array}$ \\
\hline Site 4, Rep 2 & $\begin{array}{r}0(a) \\
337(a) \\
15909(b)\end{array}$ & $\begin{array}{r}33.5 \\
18.6 \\
7.7\end{array}$ \\
\hline Site $5, \operatorname{Rep} 1$ & $\begin{array}{r}0(a) \\
337(a) \\
19682(b)\end{array}$ & $\begin{array}{r}25.0 \\
12.0 \\
8.1\end{array}$ \\
\hline Site 5, Rep 2 & $\begin{array}{r}0(a) \\
337(a) \\
16725(b)\end{array}$ & $\begin{array}{r}32.5 \\
16.7 \\
6.1\end{array}$ \\
\hline
\end{tabular}

${ }^{1}$ Method of analysis:

(a) Pressure plate extractor or

(b) Thermocouple psychrometer 
Table 28.--Infiltration rate and hydraulic conductivity of the landfill cover, Municipal Solid Waste Landfill Facility, U.S. Army Air Defense Artillery Center and Fort Bliss, El Paso, Texas

$$
[\mathrm{cm} / \mathrm{sec} \text {, centimeter per second] }
$$

\begin{tabular}{cccccc}
\hline & \multicolumn{2}{c}{ Infiltration rate $^{1}$} & \multicolumn{2}{c}{ Hydraulic conductivity $^{2}$} \\
\cline { 2 - 3 } Sample number & $\begin{array}{c}\text { Saturated } \\
\left(\times 10^{-3} \mathrm{~cm} / \mathrm{sec}\right)\end{array}$ & $\begin{array}{c}\text { Unsaturated }^{4} \\
\left(\times 10^{-3} \mathrm{~cm} / \mathrm{sec}^{2}\right)\end{array}$ & $\begin{array}{c}\text { Saturated } \\
\left(\times 10^{3} \mathrm{~cm} / \mathrm{sec}\right)\end{array}$ & $\begin{array}{c}\text { Unsaturated }^{4} \\
\left(\times 10^{-3} \mathrm{~cm} / \mathrm{sec}\right)\end{array}$ \\
\hline Site 1, Rep 1 & 2.63 & 1.42 & 1.16 & 0.63 \\
Site 1, Rep 2 & 2.73 & 1.65 & 1.09 & 0.65 \\
Site 2, Rep 1 & 2.25 & 1.27 & 0.96 & 0.54 \\
Site 2, Rep 2 & 1.98 & 1.02 & 0.92 & 0.47 \\
Site 3, Rep 1 & 3.38 & 1.52 & 1.69 & 0.76 \\
Site 3, Rep 2 & 2.61 & 1.10 & 1.35 & 0.57 \\
Site 4, Rep 1 & 3.5 & 2.01 & 1.46 & 0.84 \\
Site 4, Rep 2 & 3.56 & 1.89 & 1.59 & 0.85 \\
Site 5, Rep 1 & 5.00 & 1.15 & 3.12 & 0.72 \\
Site 5, Rep 2 & 6.75 & 1.79 & 4.09 & 1.09 \\
\hline
\end{tabular}

${ }^{1}$ In situ measurements of the landfill cover

${ }^{2}$ Values derived from in situ infiltration data

${ }^{3}$ Saturated measurements made with 0.5 -centimeter ponded water head

${ }^{4}$ Unsaturated measurements made at 3-centimeter tension 
Table 29.--Analytical results of soil-moisture and soil-chloride data for soil samples collected from cores from the Municipal Solid Waste Landfill Facility, U.S. Army Air Defense

Artillery Center and Fort Bliss, El Paso, Texas

\begin{tabular}{|c|c|c|c|c|c|c|}
\hline $\begin{array}{c}\text { Depth } \\
\text { (feet below } \\
\text { land surface) }\end{array}$ & $\begin{array}{c}\text { Soil } \\
\text { water in } \\
\text { sample } \\
\text { (grams) }\end{array}$ & $\begin{array}{l}\text { Dry soil } \\
\text { in sample } \\
\text { (grams) }\end{array}$ & $\begin{array}{l}\text { Bulk } \\
\text { density } \\
\text { of soil } \\
\text { (grams per } \\
\text { cubic } \\
\text { centimeter) }\end{array}$ & $\begin{array}{l}\text { Volumetric } \\
\text { moisture } \\
\text { content } \\
\text { (fraction) }\end{array}$ & $\begin{array}{c}\text { Soil- } \\
\text { water } \\
\text { chloride } \\
\text { concentration }{ }^{2} \\
\text { (milligrams per } \\
\text { liter) }\end{array}$ & $\begin{array}{c}\text { Soil } \\
\text { chloride } \\
\text { rontent } \\
\text { (micrograms } \\
\text { p rr cubic } \\
\text { centimeter) }\end{array}$ \\
\hline 2 & 3.0 & 121.8 & 1.5 & 0.037 & 151.5 & 5.596 \\
\hline 4 & 3.6 & 82.9 & 1.5 & 0.065 & 54.2 & 3.532 \\
\hline 5 & 2.3 & 48.6 & 1.5 & 0.071 & 26.8 & 1.904 \\
\hline 6 & 1.8 & 52.7 & 1.5 & 0.051 & 91.5 & 4.688 \\
\hline 7 & 2.9 & 41.4 & 1.5 & 0.105 & 33.7 & 3.542 \\
\hline 8 & 3.3 & 63.5 & 1.5 & 0.078 & 77.3 & 6.028 \\
\hline 9 & 2.8 & 35.1 & 1.5 & 0.120 & 71.8 & 8.588 \\
\hline 10 & 2.7 & 45.5 & 1.5 & 0.089 & 135.8 & 12.086 \\
\hline 11 & 3.0 & 46.7 & 1.5 & 0.096 & 84.9 & 8.178 \\
\hline 12 & 4.2 & 66.0 & 1.5 & 0.095 & 60.5 & 5.775 \\
\hline 13 & 2.8 & 51.0 & 1.5 & 0.082 & 77.3 & 6.362 \\
\hline 14 & 6.9 & 52.1 & 1.45 & 0.192 & 19.5 & 3.744 \\
\hline 15 & 7.6 & 47.4 & 1.55 & 0.249 & 45.7 & 11.348 \\
\hline 16 & 2.0 & 117.9 & 1.5 & 0.025 & 42.3 & 1.076 \\
\hline 19 & 3.2 & 176.2 & 1.5 & 0.027 & 41.0 & 1.116 \\
\hline 20 & 1.6 & 129.5 & 1.5 & 0.019 & 90.8 & 1.682 \\
\hline 24 & 1.7 & 141.5 & 1.5 & 0.018 & $1,812.6$ & 32.665 \\
\hline 25 & 2.4 & 162.5 & 1.5 & 0.022 & 903.0 & 20.005 \\
\hline 26 & 2.5 & 146.6 & 1.5 & 0.026 & $1,563.1$ & 39.984 \\
\hline 28 & 1.4 & 144.4 & 1.5 & 0.015 & $2,605.9$ & 37.897 \\
\hline 29 & 1.4 & 129.5 & 1.49 & 0.016 & 836.2 & 13.470 \\
\hline 30 & 1.9 & 146.6 & 1.5 & 0.019 & 732.6 & 14.243 \\
\hline 33 & 3.2 & 141.0 & 1.5 & 0.034 & 642.8 & 21.883 \\
\hline 34 & 1.7 & 133.7 & 1.6 & 0.020 & $1,909.4$ & 38.845 \\
\hline 35 & 3.4 & 157.7 & 1.6 & 0.034 & $1,148.2$ & 39.609 \\
\hline 36 & 3.3 & 121.8 & 1.6 & 0.043 & 910.6 & 39.476 \\
\hline 37 & 1.7 & 128.1 & 1.6 & 0.021 & 388.2 & 8.244 \\
\hline 38 & 2.2 & 112.1 & 1.6 & 0.031 & 393.4 & 12.353 \\
\hline 39 & 2.5 & 124.2 & 1.6 & 0.032 & 263.0 & 8.471 \\
\hline 40 & 3.3 & 140.6 & 1.6 & 0.038 & 366.1 & 13.747 \\
\hline 42 & 2.1 & 138.9 & 1.7 & 0.026 & 345.1 & 8.871 \\
\hline
\end{tabular}


Table 29.--Analytical results of soil-moisture and soil-chloride data for soil samples collected from cores from the Municipal Solid Waste Landfill Facility, U.S. Army Air Defense

Artillery Center and Fort Bliss, El Paso, Texas--Concluded

\begin{tabular}{|c|c|c|c|c|c|c|}
\hline $\begin{array}{c}\text { Depth } \\
\text { (feet below } \\
\text { land surface) }\end{array}$ & $\begin{array}{c}\text { Soil } \\
\text { water in } \\
\text { sample } \\
\text { (grams) }\end{array}$ & $\begin{array}{l}\text { Dry soil } \\
\text { in sample } \\
\text { (grams) }\end{array}$ & $\begin{array}{c}\text { Bulk } \\
\text { density } \\
\text { of soil } \\
\text { (grams per } \\
\text { cubic } \\
\text { centimeter) }\end{array}$ & $\begin{array}{l}\text { Volumetric } \\
\text { moisture } \\
\text { content } \\
\text { (fraction) }\end{array}$ & $\begin{array}{c}\text { Soil- } \\
\text { water } \\
\text { chloride } \\
\text { concentration }{ }^{2} \\
\text { (milligrams per } \\
\text { liter) }\end{array}$ & $\begin{array}{c}\text { Scil } \\
\text { chlo'ide } \\
\text { content } \\
\text { (micromrams } \\
\text { per c'1bic } \\
\text { centimeter) }\end{array}$ \\
\hline 43 & 2.5 & 145.7 & 1.7 & 0.029 & 316.2 & 9.223 \\
\hline 44 & 2.9 & 158.4 & 1.7 & 0.031 & 518.1 & 16.125 \\
\hline 45 & 5.3 & 172.4 & 1.68 & 0.052 & 471.1 & 24.332 \\
\hline 46 & 2.7 & 157.5 & 1.7 & 0.029 & 610.0 & 17.777 \\
\hline 48 & 3.0 & 126.5 & 1.7 & 0.040 & 762.5 & 30.742 \\
\hline 49 & 3.6 & 111.4 & 1.7 & 0.055 & 732.2 & 40.225 \\
\hline 51 & 3.0 & 152.3 & 1.7 & 0.033 & 853.3 & 28.575 \\
\hline 52 & 3.1 & 164.7 & 1.7 & 0.032 & 985.5 & 31.533 \\
\hline 55 & 2.6 & 135.5 & 1.7 & 0.033 & $1,358.5$ & 44.315 \\
\hline 92 & 15.0 & 73.0 & 1.59 & 0.327 & - & 14.567 \\
\hline 94 & 15.9 & 109.3 & 1.73 & 0.252 & - & 19.595 \\
\hline 109 & 14.1 & 94.6 & 1.75 & 0.261 & - & 21.696 \\
\hline 118 & 8.9 & 69.8 & 1.8 & 0.230 & - & 4.376 \\
\hline 120 & 12.8 & 62.8 & 1.8 & 0.367 & - & 29.479 \\
\hline 143 & 8.5 & 74.5 & 1.83 & 0.209 & - & 71.232 \\
\hline 151 & 10.5 & 92.5 & 1.85 & 0.210 & - & 3.455 \\
\hline 164 & 14.0 & 74.7 & 1.63 & 0.305 & - & 8.421 \\
\hline 176 & 7.2 & 93.0 & 1.6 & 0.124 & - & 10.173 \\
\hline 199 & 18.4 & 103.4 & 1.56 & 0.278 & - & 31.137 \\
\hline 233 & 13.8 & 62.7 & 1.03 & 0.227 & - & 11.330 \\
\hline 236 & 14.5 & 68.5 & 1.56 & 0.330 & - & 30.162 \\
\hline 245 & 10.5 & 59.8 & 1.6 & 0.281 & - & 10.899 \\
\hline 284 & 20.2 & 103.2 & 1.65 & 0.323 & - & 25.131 \\
\hline 290 & 15.2 & 81.4 & 1.66 & 0.310 & - & 20.197 \\
\hline 298 & 13.4 & 103.6 & 1.52 & 0.197 & - & 26.673 \\
\hline 316 & 21.7 & 104.1 & 1.63 & 0.340 & - & 32.741 \\
\hline 325 & 11.8 & 44.7 & 1.6 & 0.422 & - & 5.658 \\
\hline
\end{tabular}

${ }^{1}$ An increase in soil water was observed in samples collected from core recovered using mud-rotary drilling compared with samples collected from core recovered using hollow-stem auger drilling

${ }^{2}$ Soil-water chloride concentration not determined for samples collected from core recovered using mudrotary drilling because of possible influence of moisture from drilling mud on soil water in soil sample. 
Table 30.--Analytical results ${ }^{1}$ of ground-water sample collected from well MSV'LF03, Municipal Solid Waste Landfill Facility, U.S. Army Air Defense Artillery Certer and Fort Bliss, El Paso, Texas

[Qualifier codes are identified in table 18. --, no data; NTUs, nephelometric turtidity units; $\mathrm{mS} / \mathrm{cm}$, microsiemens per centimeter at 25 degrees Celsius; $\mathrm{mg} / \mathrm{L}$, milligrams per liter; mg/L, micrograms per liter; ND, not detected]

\begin{tabular}{|c|c|c|c|}
\hline Parameter and unit & Method $^{2}$ & $\begin{array}{l}\text { Reporting } \\
\text { limit }\end{array}$ & $\begin{array}{l}\text { Well MSUTF03 } \\
\text { result/qualifier }\end{array}$ \\
\hline Date & - & - & 19-Feb-97 \\
\hline Time & - & - & 1515 \\
\hline USGS sample number & -- & - & MSWLF0310 \\
\hline Laboratory sample number & - & - & 053820-0001-SA \\
\hline $\begin{array}{l}\text { Water-level elevation, feet above sea level, prior } \\
\text { to pumping }\end{array}$ & - & 0.01 & $3,601.10$ \\
\hline $\begin{array}{l}\text { Amount purged prior to sampling, } \\
\text { gallons }\end{array}$ & - & 1 & 110 \\
\hline Depth sampled, feet below land surface & -- & 1 & 325 \\
\hline \multicolumn{4}{|l|}{ Field properties: } \\
\hline Temperature, degrees Celsius & E170.1 & 0.1 & 21.3 \\
\hline Turbidity, NTUs & E180.1 & 1 & 4.07 \\
\hline $\mathrm{pH}$ & E150.1 & 0.1 & 8.10 \\
\hline Specific conductance, $\mu \mathrm{S} / \mathrm{cm}$ & E120.1 & 10.0 & 521 \\
\hline Alkalinity, total, mg/L & E310.1 & 5.0 & 136 \\
\hline Alkalinity, bicarbonate, $\mathrm{mg} / \mathrm{L}$ & E310.1 & 5.0 & 136 \\
\hline Alkalinity, carbonate, mg/L & E310.1 & 5.0 & ND \\
\hline Alkalinity, hydroxide, mg/L & E310.1 & 5.0 & ND \\
\hline Dissolved solids, $\mathrm{mg} / \mathrm{L}$ & E160.1 & 10.0 & 327 \\
\hline \multicolumn{4}{|l|}{ Common ions: } \\
\hline Chloride, total, $\mathrm{mg} / \mathrm{L}$ & E300 & 0.50 & 38.6 \\
\hline Fluoride, total, $\mathrm{mg} / \mathrm{L}$ & E300 & 0.50 & 0.79 \\
\hline Nitrate as nitrogen, total, $\mathrm{mg} / \mathrm{L}$ & E300 & 0.50 & 2.0 \\
\hline Ammonia as nitrogen, total, $\mathrm{mg} / \mathrm{L}$ & E350.1 & 0.10 & ND \\
\hline Orthophosphate as phosphorus, total, mg/L & E300 & 0.50 & ND \\
\hline Sulfate, total, $\mathrm{mg} / \mathrm{L}$ & E300 & 0.50 & 48.6 \\
\hline Calcium, dissolved, $\mathrm{mg} / \mathrm{L}$ & SW6010 & 5.0 & 17.4 \\
\hline Magnesium, dissolved, mg/L & SW6010 & 5.0 & 5.5 \\
\hline Potassium, dissolved, $\mathrm{mg} / \mathrm{L}$ & SW6010 & 5.0 & 9.0 \\
\hline
\end{tabular}


Table 30.--Analytical results ${ }^{1}$ of ground-water sample collected from well MSWLF03, Municipal Solid Waste Landfill Facility, U.S. Army Air Defense Artillery Center and Fort Bliss, El Paso, Texas--Continued

\begin{tabular}{|c|c|c|c|}
\hline Parameter and unit & Method $^{2}$ & $\begin{array}{l}\text { Reporting } \\
\text { limit }\end{array}$ & $\begin{array}{l}\text { Well MSWLF0E } \\
\text { result/qualifier }\end{array}$ \\
\hline \multicolumn{4}{|l|}{ Common ions--Continued: } \\
\hline Sodium, dissolved, mg/L & SW6010 & 5.0 & 77.0 \\
\hline \multicolumn{4}{|l|}{ Volatile organic compounds: } \\
\hline Acetone, $\mathrm{mg} / \mathrm{L}$ & SW8260 & 10 & ND \\
\hline Benzene, $\mathrm{mg} / \mathrm{L}$ & SW8260 & 1.0 & ND \\
\hline Bromodichloromethane, $\mathrm{mg} / \mathrm{L}$ & SW8260 & 1.0 & ND \\
\hline Bromoform, mg/L & SW8260 & 1.0 & ND \\
\hline Bromomethane, mg/L & SW8260 & 2.0 & ND \\
\hline Carbon disulfide, $\mathrm{mg} / \mathrm{L}$ & SW8260 & 1.0 & ND \\
\hline Carbon tetrachloride, $\mathrm{mg} / \mathrm{L}$ & SW8260 & 1.0 & ND \\
\hline Chlorobenzene, mg/L & SW8260 & 1.0 & ND \\
\hline Chloroethane, mg/L & SW8260 & 2.0 & ND \\
\hline Chloroform, mg/L & SW8260 & 1.0 & ND \\
\hline Chloromethane, $\mathrm{mg} / \mathrm{L}$ & SW8260 & 2.0 & ND \\
\hline Dibromochloromethane, $\mathrm{mg} / \mathrm{L}$ & SW8260 & 1.0 & ND \\
\hline Ethylbenzene, $\mathrm{mg} / \mathrm{L}$ & SW8260 & 1.0 & ND \\
\hline Methylene chloride, $\mathrm{mg} / \mathrm{L}$ & SW8260 & 1.0 & ND \\
\hline Styrene, $\mathrm{mg} / \mathrm{L}$ & SW8260 & 1.0 & ND \\
\hline Tetrachloroethene, mg/L & SW8260 & 1.0 & ND \\
\hline Toluene, $\mathrm{mg} / \mathrm{L}$ & SW8260 & 1.0 & ND \\
\hline Trichloroethene, $\mathrm{mg} / \mathrm{L}$ & SW8260 & 1.0 & ND \\
\hline Vinyl chloride, mg/L & SW8260 & 2.0 & ND \\
\hline Xylenes (total), $\mathrm{mg} / \mathrm{L}$ & SW8260 & 1.0 & ND \\
\hline cis-1,3-Dichloropropene, mg/L & SW8260 & 1.0 & ND \\
\hline trans-1,3-Dichloropropene, $\mathrm{mg} / \mathrm{L}$ & SW8260 & 1.0 & $\mathrm{ND}$ \\
\hline 1,1,1-Trichloroethane, $\mathrm{mg} / \mathrm{L}$ & SW8260 & 1.0 & ND \\
\hline 1,1,2,2-Tetrachloroethane,mg/L & SW8260 & 1.0 & ND \\
\hline
\end{tabular}


Table 30.--Analytical results ${ }^{1}$ of ground-water sample collected from well MSV/LF03, Municipal Solid Waste Landfill Facility, U.S. Army Air Defense Artillery Cer ${ }^{+} e r$ and Fort Bliss, El Paso, Texas--Concluded

\begin{tabular}{|c|c|c|c|}
\hline Parameter and unit & Method $^{2}$ & $\begin{array}{l}\text { Reporting } \\
\text { limit }\end{array}$ & $\begin{array}{l}\text { Well MSULF03 } \\
\text { result/qualifier }\end{array}$ \\
\hline \multicolumn{4}{|c|}{ Volatile organic compounds--Continued: } \\
\hline 1,1,2-Trichloroethane, $\mathrm{mg} / \mathrm{L}$ & SW8260 & 1.0 & ND \\
\hline 1,1-Dichloroethane, mg/L & SW8260 & 1.0 & ND \\
\hline 1,1-Dichloroethene, mg/L & SW8260 & 1.0 & ND \\
\hline 1,2-Dichloroethane, $\mathrm{mg} / \mathrm{L}$ & SW8260 & 1.0 & ND \\
\hline 1,2-Dichloroethene (total), $\mathrm{mg} / \mathrm{L}$ & SW8260 & 1.0 & ND \\
\hline 1,2-Dichloropropane, $\mathrm{mg} / \mathrm{L}$ & SW8260 & 1.0 & ND \\
\hline 2-Butanone (MEK), mg/L & SW8260 & 5.0 & ND \\
\hline 2-Hexanone, $\mathrm{mg} / \mathrm{L}$ & SW8260 & 5.0 & ND \\
\hline 4-Methyl-2-pentanone, $\mathrm{mg} / \mathrm{L}$ & SW8260 & 5.0 & ND \\
\hline \multicolumn{4}{|l|}{ Metals: } \\
\hline Arsenic, dissolved, $\mathrm{mg} / \mathrm{L}$ & SW6010 & 0.010 & ND \\
\hline Barium, dissolved, $\mathrm{mg} / \mathrm{L}$ & SW6010 & 0.10 & ND \\
\hline Cadmium, dissolved, mg/L & SW6010 & 0.0050 & ND \\
\hline Chromium, dissolved, $\mathrm{mg} / \mathrm{L}$ & SW6010 & 0.030 & ND \\
\hline Cobalt, dissolved, $\mathrm{mg} / \mathrm{L}$ & SW6010 & 0.040 & ND \\
\hline Copper, dissolved, $\mathrm{mg} / \mathrm{L}$ & SW6010 & 0.030 & ND \\
\hline Iron, dissolved, mg/L & SW6010 & 0.040 & ND \\
\hline Lead, dissolved, $\mathrm{mg} / \mathrm{L}$ & SW6010 & 0.0040 & $\mathrm{ND} / \mathrm{g}$ \\
\hline Nickel, dissolved, mg/L & SW6010 & 0.040 & $\mathrm{ND}$ \\
\hline Selenium, dissolved, $\mathrm{mg} / \mathrm{L}$ & SW7740 & 0.010 & $\mathrm{ND} / \mathrm{g}$ \\
\hline
\end{tabular}

${ }^{1}$ Analyses performed by Quanterra Environmental Services, Arvada, Colorado

${ }^{2}$ Method numbers preceded by $E$ are from:

U.S. Environmental Protection Agency (1983; 1986a,b)

Method numbers preceded by SW are from:

U.S. Environmental Protection Agency (1986c) 
Table 31.--Summary of maximum contaminant levels for selected water-quality constituents and properties for public water-supply systems ${ }^{1}$

$$
[--, \text { no data; } \mathrm{mg} / \mathrm{L}, \text { milligrams per liter }]
$$

\begin{tabular}{lcc}
\hline \multicolumn{1}{c}{ Constituent } & Maximum contaminant level ${ }^{2}$ & $\begin{array}{c}\text { Secondary maximum } \\
\text { contaminant level }^{3}\end{array}$ \\
\hline pH (standard units) & - & $6.5-8.5$ \\
Dissolved solids & - & $500 \mathrm{mg} / \mathrm{L}$ \\
Chloride, total & $4.0 \mathrm{mg} / \mathrm{L}$ & $250 \mathrm{mg} / \mathrm{L}$ \\
Fluoride, total & $10 \mathrm{mg} / \mathrm{L}$ & $2.0 \mathrm{mg} / \mathrm{L}$ \\
Nitrate as nitrogen, total & - & - \\
Sulfate, total & $0.05 \mathrm{mg} / \mathrm{L}$ & $250 \mathrm{mg} / \mathrm{L}$ \\
Arsenic, total & $2 \mathrm{mg} / \mathrm{L}$ & - \\
Barium, total & $0.005 \mathrm{mg} / \mathrm{L}$ & - \\
Cadmium, total & $0.1 \mathrm{mg} / \mathrm{L}$ & - \\
Chromium, total & - & $1.0 \mathrm{mg} / \mathrm{L}$ \\
Copper, total & - & $0.3 \mathrm{mg} / \mathrm{L}$ \\
Iron, total & $0.1 \mathrm{mg} / \mathrm{L}$ & - \\
Nickel, total & $0.05 \mathrm{mg} / \mathrm{L}$ & - \\
Selenium, total & & - \\
\hline
\end{tabular}

${ }^{1}$ Public water-supply system--A system for the provision of piped water to the public for human consumption, if such system has at least 15 service connections or regularly serves at least 25 individuals daily at least 60 days of the year

${ }^{2}$ Maximum contaminant level--Maximum permissible level of a contaminant in water that is delivered to the free-flowing outlet of the ultimate user of a public water system. Maximum contaminant levels are those levels set by the U.S. Environmental Protection Agency (1994) in the national primary drinking water regulations. These regulations deal with contaminants that may have a substantial direct impact on the health of the consumer and are enforceable by Federal law

${ }^{3}$ Secondary maximum contaminant level--Advisable maximum level of a contaminant in water that is delivered to a free-flowing outlet of the ultimate user of a public water system. Secondary maximum contaminant levels are those levels proposed by the U.S. Environmental Protection Agency (1996) in the national secondary drinking water regulations--These regulations deal with contaminants that may not have a substantial direct impact on the health of the consumer, but their presence in excessive quantities may affect the aesthetic qualities of the water and may discourage the use of a drinking-water supply by the public 